\title{
Palynology of the
}

Upper Campanian (Cretaceous)

Judith River Formation,

North-Central Montana

GEOLOGICAL SURVEY PROFESSIONAL PAPER 770 



\section{Palynology of the Upper Campanian (Cretaceous) Judith River Formation, North-Central Montana}

By BERNADINE D. TSCHUDY

GEOLOGICAL SURVEY PROFESSIONAL PAPER 770

Identification of fossil pollen and spores in rocks from the type area

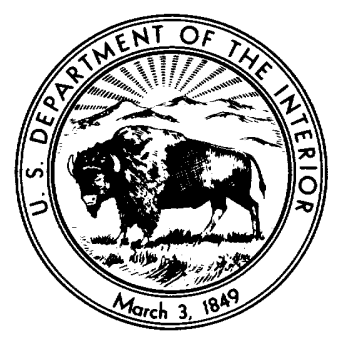


UNITED STATES DEPARTMENT OF THE INTERIOR

ROGERS C. B. MORTON, Secretary

\section{GEOLOGICAL SURVEY}

V. E. McKelvey, Director

Library of Congress catalog-card No. 72-600366

For sale by the Superintendent of Documents, U.S. Government Printing Office, Washington, D.C. 20402 Price: Paper cover-\$1.25, domestic postpaid; \$1.00, GPO Bookstore. Stock No. 2401-00291 


\section{CONTENTS}

Abstract

Introduction

The Judith River Formation

Sample localities

Processing of samples and photography

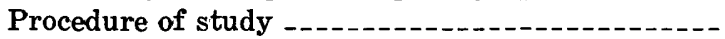

Depository of types and other illustrated specimens

Acknowledgments -........ Pollen-spore zones

Systematics

Triletes

Genus Cyathidites Couper, 1953

Genus Deltoidospora Miner, 1935 emend. Potonié, 1956

Genus Stereisporites Pflug in Thomson and Pflug, 1953

Genus Leptolepidites Couper, 1953 emend. Potonié, 1966

Genus Baculatisporites Pflug and Thomson in Thomson and Pflug, 1953

Genus Osmundacidites Couper, 1953 ...........

Genus Kuylisporites Potonié, 1956

Genus Ischyosporites Balme, 1957

Genus Cicatricosisporites Potonié and Gelletich, 1933 emend. Potonié, 1966

Genus Ghoshispora Srivastava, 1966 sensu Leffingwell, 1971

Genus Foraminisporis Krutzsch, 1959a Genus Polycingulatisporites Simoncsics and Kedves, 1961 emend. Playford and Dettmann, 1965

Genus Trisolissporites n. gen -.......--

Genus Gleicheniidites Ross, 1949 emend.

Skarby, 1964

Genus Camarozonosporites Pant ex Potonié, 1956 emend. Klaus, 1960

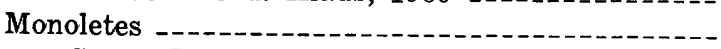

Genus Laevigatosporites Ibrahim, 1933 emend. Schopf, Wilson, and Bentall, 1944 --

Genus Umbosporites Newman, 1965 ...----

Genus Microfoveolatosporis Krutzsch, 1959a

Zonates

Genus Seductisporites Chlonova, 1961

Genus Zonalapollenites Pflug in Thomson and Pfiug, 1953

Bisaccates -..---

Genus Alisporites Daugherty, 1941 -

Genus Abietineaepollenites Potonié, 1951 ex

Delcourt and Sprumont, 1955

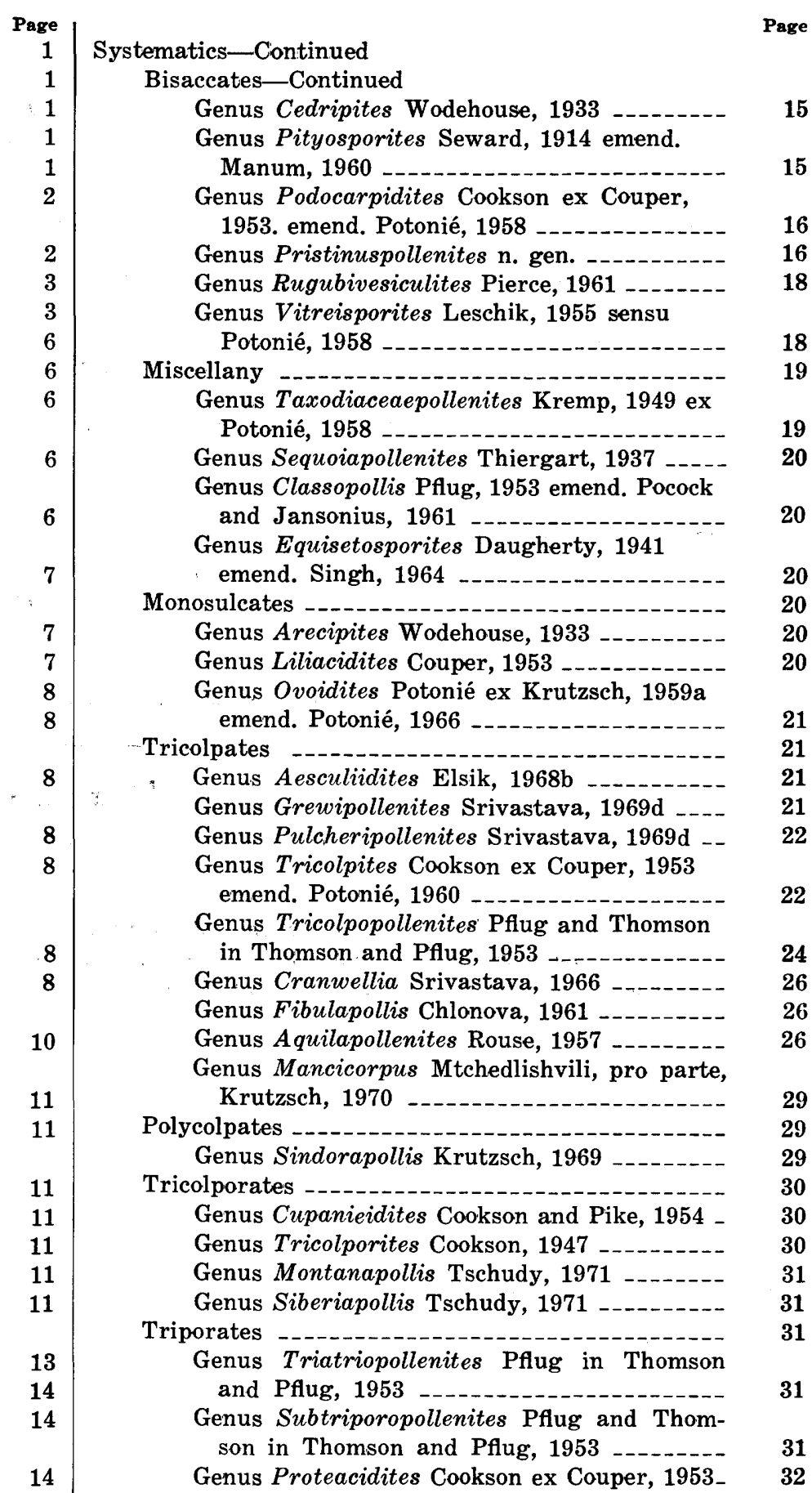

III 
Systematics-Continued

Polyporates

Genus Periporopollenites Pflug and Thomson emend. Krutzsch, 1966

Genus Erdtmanipollis Krutzsch, 1962

Dyads

Genus Dyadonapites Erdtman, 1947 ex Tschudy (this report)
Page

32

32

32

32

32

Systematics-Continued

Tetrads

Genus Inaperturotetradites van Hoeken-

Klinkenberg, 1964

Genus Droseridites Cookson, 1947 ex Potonié, 1960 _...... 33

References cited -

Page

Index

32

39

\section{ILLUSTRATIONS}

[Plates follow index]

PLATE 1. Cyathidites, Deltoidospora, Stereisporites, Leptolepidites, Baculatisporites, Osmundacidites, Kuylisporites, Ischyosporites, Cicatricosisporites, Ghoshispora.

2. Foraminisporis, Polycingulatisporites, Trisolissporites, and Dulhuntyispora.

3. Gleicheniidites, Camarozonosporites, Laevigatosporites, Umbosporites, Microfoveolatosporis, and Seductisporites.

4. Seductisporites.

5. Zonalapollenites, Alisporites, Abietineaepollenites, Cedripites, and Pityosporites.

6. Pityosporites.

7. Podocarpidites, Pristinuspollenites, and Rugubivesiculites.

8. Vitreisporites, Taxodiaceaepollenites, Sequoiapollenites, Classopollis, Equisetosporites, Arecipites, Liliacidites, Ovoidites, Aesculiidites Grewipollenites, Pulcheripollenites, and Tricolpites:

9. Tricolpopollenites, Cranwellia, Fibulapollis, and Aquilapollenites.

10. Aquilapollenites, Mancicorpus, Sindorapollis, Cupanieidites, and Tricolporites.

11. Montanapollis, Siberiapollis, Triatriopollenites, Subtriporopollenites, Proteacidites, Periporopollenites, Erdtmanipollis, Dyadonapites, Inaperturotetradites, and Droseridites.

FIGURE 1. Composite section showing stratigraphic position of pollen-spore collections from Judith River Formation 2. Index map showing sample localities

Index map showing sample localities

-

\section{TABLES}

TABLE 1. Stratigraphic distribution of pollen and spores

2. Pollen-spore zones, based on selected taxa from table 1

3. Abundance ratios between two pairs of pollen species 


\title{
PALYNOLOGY OF THE UPPER CAMPANIAN (CRETACEOUS) JUDITH RIVER FORMATION, NORTH-CENTRAL MONTANA
}

\author{
By Bernadine D. Tschudy
}

\begin{abstract}
A large assemblage of well-preserved fossil pollen and spores was found to be incorporated in 13 samples from upper Campanian rocks from the type area of the Judith River Formation near the Missouri River in north-central Montana. Three fairly distinct zones and one transition zone, on the basis of the extracted palynomorphs, were recognized within the composite section studied. Most of the microfossils morphologically worthy of taxonomic designations were assignable to previously known species and (or) genera; but two new genera, 10 new species, and one new variety were named and described to accommodate new taxa. The palynomorph assemblages recovered from the 13 samples of the section are listed in stratigraphic sequence, and the taxa are illustrated.
\end{abstract}

\section{INTRODUCTION}

Preliminary palynological work on 18 rock samples furnished by J. R. Gill and L. G. Schultz from a composite section from the type areas of the Claggett Shale and Judith River Formation in north-central Montana disclosed a large assemblage of well-preserved palynomorphs. This report incorporates the results of extensive work on 13 samples from five collection localities from the Judith River Formation part of the composite section. The purpose of the study was the identification of the taxa that make up the Judith River Formation pollen and spore assemblage.

\section{THE JUDITH RIVER FORMATION}

Hayden (1859, p. 123-124) dramatically described the area near the mouth of the Judith River which he called the "Bad Lands of the Judith," and he later $(1871$, p. 97) formally designated the strata of the Judith basin as the "Judith Group." Stanton and Hatcher (1905, p. 11-66) summarized the history of early exploration in the region along the Missouri River near the mouth of the Judith River and described the lithologic and paleontologic features of the Judith River Formation. On the bases of early reports by Hayden and of their own observations, Stanton and Hatcher $(1905$, p. 32-33) defined "the original area of the Judith River forma- tion" as lying between the mouths of the Judith River on the west and "Little Rocky Mountain Creek" (Rock Creek) on the east and as extending both north and south of the Missouri River for about 20 miles.

The composite section (fig. 1) of the Judith River Formation in areas from which J. R. Gill and L. G. Schultz collected samples is about 775 feet thick. The lower marine part of the section was included in the Claggett Formation by Stanton and Hatcher $(1905$, p. 32, 35-36).

\section{SAMPLE LOCALITIES}

The 13 samples used in this study are the pollenspore collections which J. R. Gill and L. G. Schultz made within their composite section of the Judith River Formation in its type area. Eleven of the samples were collected near the west end of the area, at sites near the Judith River and Dog Creek south of the Missouri River and near Birch Creek north of the Missouri River. The other two samples were collected toward the east end of the area from sites slightly north of the Missouri River. The geographic localities from which the samples were collected are shown on the index map (fig. 2). Section, township, and range localities of the individual sections and the relative positions of the samples within the composite stratigraphic section are shown in figure 1.

\section{PROCESSING OF SAMPLES AND PHOTOGRAPHY}

The samples were processed and the slides prepared by standard laboratory procedures, as described by Robert H. Tschudy (1970, p. F2) .

A Zeiss photoscope was used for the photographs of all specimens. Neofluar $\times 54$ and $\times 100$ and apochromatic $\times 40$ oil-immersion objectives were used on the photoscope for all except one of the photographs; a neofluar $10 \times$ objective was used for the photograph of an extremely large spore, Ghoshispora sp. (pl. 1, fig. 17). Adox KB-14, 35-mm (millimeter) film was used for all the photographs. 


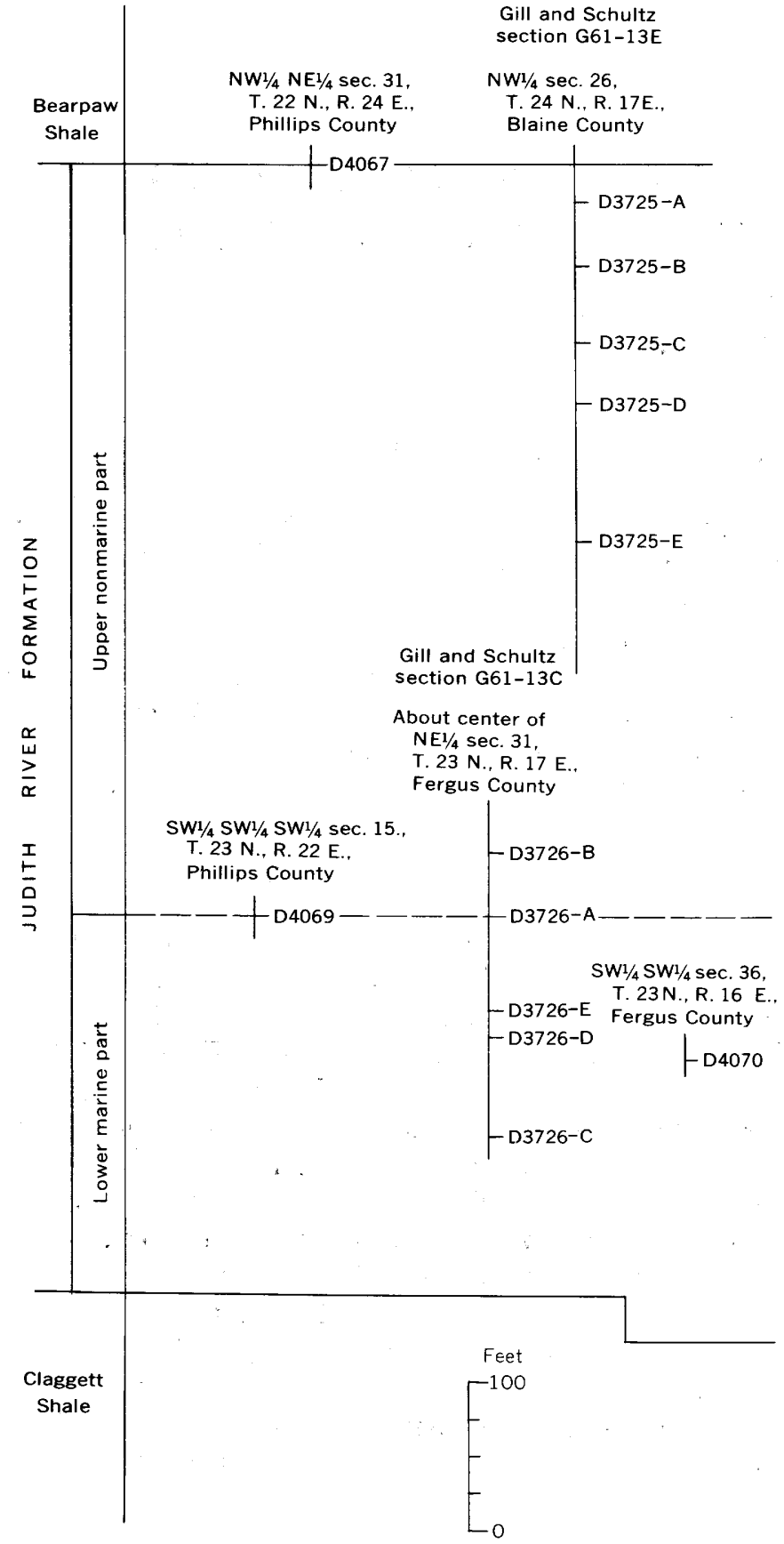

Figure 1.-Composite section showing stratigraphic position of pollen-spore collections from Judith River Formation. Collections made by J. R. Gill and L. G. Schultz in 1961 and by J. R. Gill in 1967. Data from unpublished composite section by J. R. Gill and L. G. Schultz.

\section{PROCEDURE OF STUDY}

Two hundred palynomorphs, consisting of pollen and spores, were counted under high-power $(X$ 430) magnification for each of the 13 samples used in this study (table 1). An individual count for any taxon may be divided by two to determine percentage. At least two (and for some samples as many as six) slides were scanned in search for taxa not found within the 200-count procedure; these additional taxa are indicated by the symbol $\times$. The taxa and groups of taxa in table 1 are numbered consecutively, and these numbers are used in the section "Systematics" of this report and in tables 2 and 3.

Dinoflagellates and acritarchs were found in a few of the samples throughout the section. These were not included in the counts show $n$ in table 1 . In samples where present, these made up 2 percent or less of the total palynomorph counts.

Most of the taxa that were morphologically worthy of taxonomic designations were assignable to previously known and described species and (or) genera. A few of these genera and species are redescribed on the basis of the additional data obtained from the Judith River Formation specimens, but new descriptions are furnished only if contributions to previous descriptions can be made.

Two new genera, 10 new species, and one new variety were named and described to accommodate new taxa. Several of the new species occurred in the samples in very low frequency but were numerically well represented on the slides and were conspicuous elements of the microfossil assemblage. Some of these new species apparently have limited stratigraphic ranges. All descriptions of new species except one were based on at least 15 specimens. Two additional new genera and their respective type species were named and described from samples of this series of Judith River Formation samples in an earlier report (Tschudy, 1971).

During the literature search involved in the systematic part of this study several taxonomic problems were evident. The problems are discussed, and attempts are made to contribute to their resolutions.

\section{DEPOSITORY OF TYPES AND OTHER ILLUSTRATED SPECIMENS}

All specimens found in samples of the Judith River Formation that are illustrated in this report are deposited in the slide files of the paleobotanical collections of the U.S. Geological Survey, Denver, Colo. The type specimens are within the ink-circled areas on the slides but may also be located by the mechanical stage coordinates which are given in the plate explanations, this report. These coordinates may be converted to those of another mechanical stage as explained by Tschudy $(1969, \mathrm{p}$. A1) or Tschudy (1971, p. B53). 


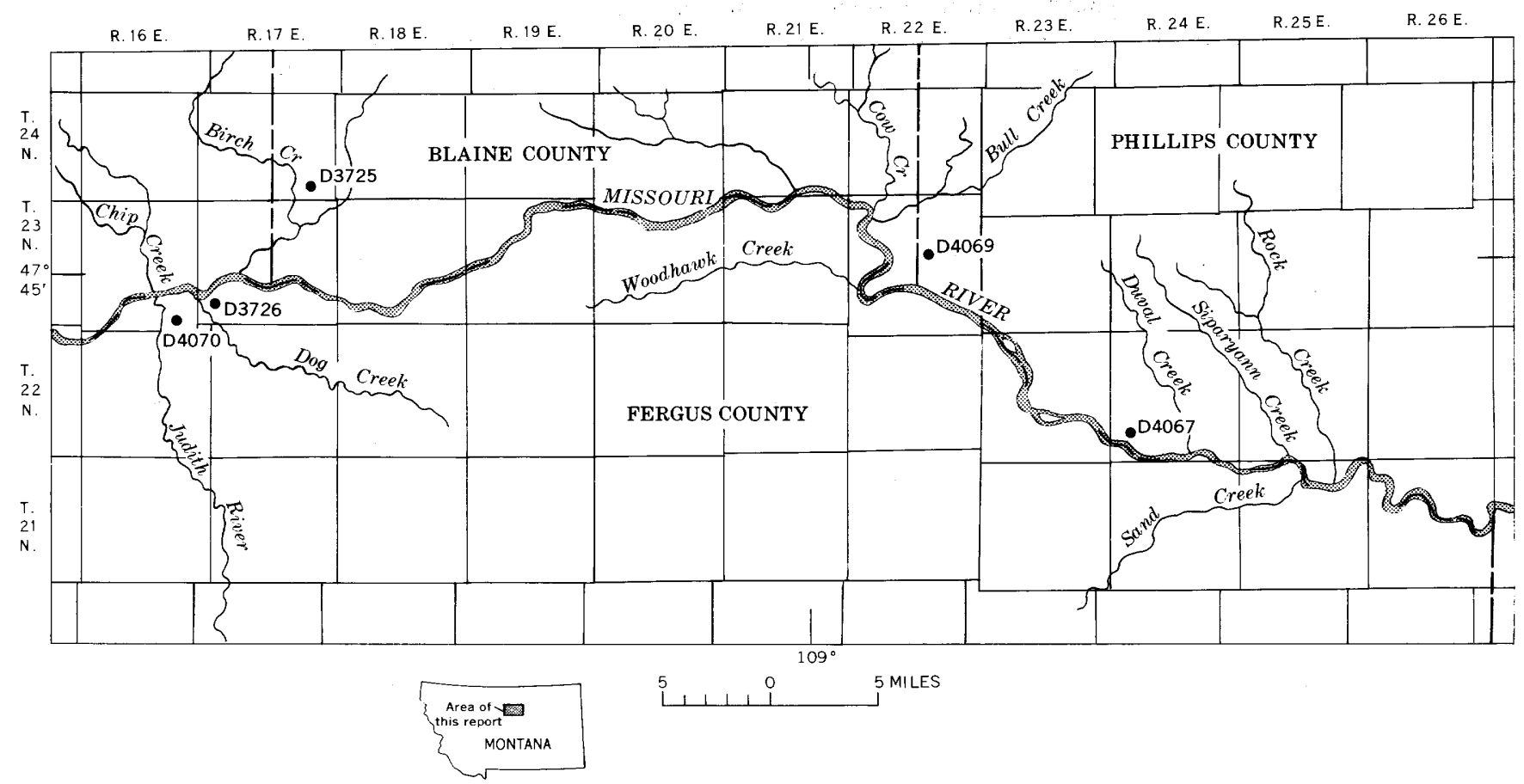

Figure 2.-Index map showing sample localities.

\section{ACKNOWLEDGMENTS}

Many people contributed to this study and their help is appreciated. Dr. B. E. Balme furnished a slide containing specimens of Dulhuntyispora which were useful for comparison with species of the new genus Trisolissporites that is described in this report. J. R. Gill and L. G. Schultz furnished the rock samples and the stratigraphic information pertaining to them. Sharon Van Loenen did the laboratory preparations of the sample material. John W. Hall loaned me some of Richard L. Pierce's type specimens from the paleobotanical collection of the University of Minnesota's Botany Department.

\section{POLLEN-SPORE ZONES}

Pollen-spore zones within the section studied are not easily discernible from the total data shown in table 1; however, three zones and one transitional zone-based on 22 selected taxa from table 1-are recognizable and are indicated in table 2 . The highest sample in the section (D4067) which was believed by J. R. Gill to be Bearpaw Shale (basal) or Judith River Formation (uppermost) is palynologically similar to the next lower sample, D3725-A. These two samples make up the uppermost zone, here designated as zone 1 . The next four samples, lower in the section, contain several taxa that are not present in the uppermost zone; these four samples constitute zone 2 . The lowermost four samples of the section are palynologically distinguishable from the samples higher in the section. These contain several taxa not present in the samples above, and lack several taxa that are more or less consistently present in the upper samples. The lowermost four samples make up zone 3. Between zones 2 and 3 are three samples that have pollen and spore characteristics (based on the selected taxa) partly resembling those of the upper zone (zone 2) and partly resembling those of the lower zone (zone 3) ; these make up the transitional zone.

Many of the more abundant species and groups of taxa of the Judith River Formation assemblage range throughout the section studied, with erratic percentage occurrences from sample to sample and with no apparent trend toward greater or less abundance from the top to the bottom of the section; these taxa thus do not appear to have any stratigraphic significance within the Judith River Formation section. A few of the more abundant species, however, show trends toward higher percentage occurrence in either the lower or the upper part of the section-for example, Tricolpites reticulatus (taxon 24) and Tricolpites hians (taxon 25) are more abundant in the lower part of the section, and Tricolpopollenites levitas (taxon 29) and Tricolpopollenites tessellatus (taxon 30) are more abundant in the upper part. Ratios in table 3 clearly show this reversal in abundance of the two pairs 
TABLE 1.-Stratigraphic distribution of pollen and spores

[Counts divided by 2 =percentages. $\times$ denotes occurrence; asterisk $\left(^{*}\right)$ indicates questionable determination]

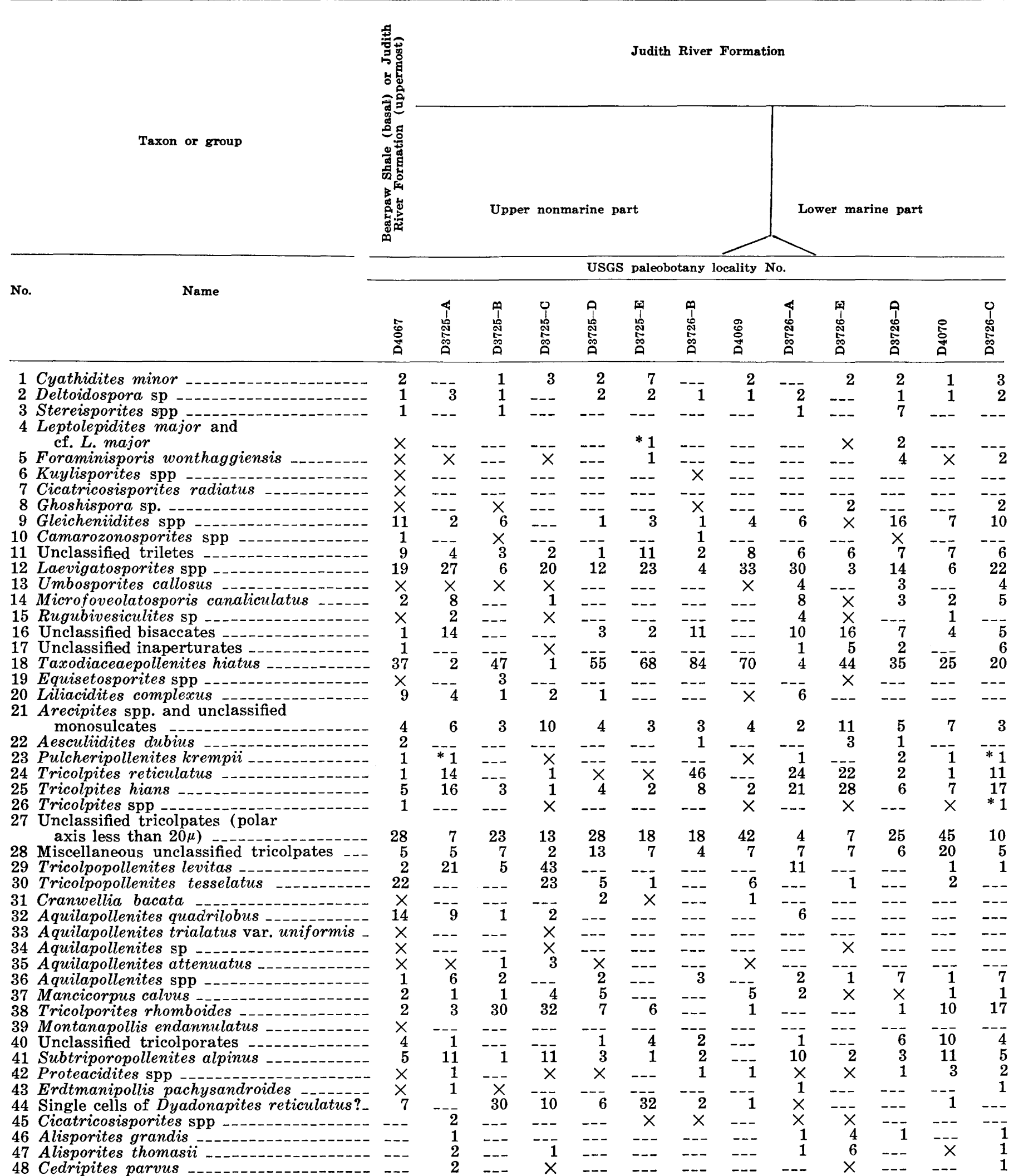


TABLE 1.-Stratigraphic distribution of pollen and spores-Continued

Taxon or group

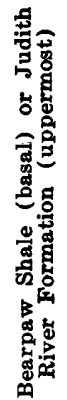

Judith River Formation

Upper nonmarine part

Lower marine part

USGS paleobotany locality No.

No.

Name

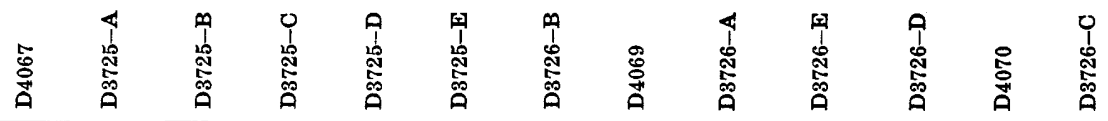

49 Pityosporites cf. $P$. constrictus _-_-_- ---

50 Pityosporites elongatus var. elongatus -- ---

51 Pityosporites elongatus var. grandis -..-

52 Podocarpidites cf. $P$. ornatus -

53 Vitreisporites pallidus _..._....... -

54 Classopollis spp _......-

55 Liliacidites variegatus _...........-

56 Liliacidites spp _._._._.

57 Cranwellia rumseyensis _............

58 Cf. Cranwellia

59 Aquilapollenites turbidus

60 Mancicorpus tripodiformis _..........

61 Triatriopollenites costatus _........

62 Unclassified triporates _............

63 Inaperturotetradites scabratus _.......

64 Baculatisporites sp _..........

65 Aquilapollenites senonicus

66 Dyadonapites reticulatus

67 Seductisporites eminens _.............

68 Cedripites cretaceus _-_.

69 Ovoidites ligneolus _.....

70 Abietineaepollenites varius

71 Aquilapollenites clarireticulatus _...-...

72 Siberiapollis montanensis -.......--

73 Osmundacidites sp

74 Ischyosporites cf. I. punctatus _......

75 Fibulapollis scabratus _............

76 Aquilapollenites trialatus

77 Aquilapollenites reticulatus _........-.

78 Sindorapollis granulatus _.........-

79 Trisolissporites montanensis _.........

80 Seductisporites gemmiferus _._._._.

81 Pityosporites alatipollenites _..........

82 Pristinuspollenites microsaccus _.-_-_.--

83 Cyathidites sp

84 Cicatricosisporites stoveri _.........

85 Polycingulatisporites spp _._._._._._.

86 Trisolissporites chlonovae

87 Seductisporites barbatus _.............

88 Zonalapollenites sp _-_._.

89 Podocarpidites multesimus

90 Sequoiapollenites spp _............

91 Cupanieidites sp _.......

92 Periporopollenites sp

93 Droseridites cf. D. spinulosus

94 Grewipollenites radiatus _.......... -

95 Liliacidites cf. L. morrinensis _.....- --

96 Tricolporites sp.

200

\begin{tabular}{|c|c|c|c|c|c|c|c|c|c|c|c|}
\hline 3 & $-\infty$ & $x$ & --- & --- & --- & $-\infty$ & -- & 3 & & --- & -- \\
\hline 3 & --- & --- & --- & --- & 2 & --- & 1 & 7 & 1 & -- & -- \\
\hline 2 & --- & --- & --- & --- & --- & $x$ & 1 & 4 & --- & --- & 1 \\
\hline$x$ & --- & --- & --- & --- & --- & --- & 2 & --- & --- & $-\ldots$ & --- \\
\hline 1 & 1 & $\cdots$ & --- & $-\ldots$ & $x$ & --- & 1 & 1 & $\overline{4}$ & $\overline{4}$ & $\overline{4}$ \\
\hline 1 & -- & --- & --- & $x$ & --- & -- & 1 & --- & --- & 1 & 2 \\
\hline 9 & 1 & 3 & -- & -- & -- & $\ldots$ & & 1 & -- & $\ldots$ & 1 \\
\hline 1 & 1 & 2 & $x$ & 1 & --- & --- & $\overline{2}$ & 1 & $\overline{2}$ & $\overline{2}$ & 1 \\
\hline$x$ & 3 & $x$ & 2 & --- & --- & --- & 3 & --- & -- & --- & --- \\
\hline$x$ & --- & --- & --- & --- & --- & --- & --- & --- & --- & --- & \\
\hline$x$ & --- & 1 & $x$ & $x$ & $x$ & $x$ & $--\overline{1}$ & $x$ & --- & $x$ & 5 \\
\hline$x$ & --- & --- & --- & --- & --- & $x$ & 1 & --- & --- & --- & -- \\
\hline 1 & $--\overrightarrow{1}$ & --- & --- & --- & $--\overline{1}$ & --- & $x$ & --- & & $--\overline{5}$ & \\
\hline 2 & 1 & 1 & 2 & 3 & 1 & 1 & 4 & $x$ & 5 & 5 & 3 \\
\hline 1 & 1 & $x$ & $-\ldots$ & $x$ & $-\cdots$ & --- & 1 & 1 & 2 & --- & 1 \\
\hline--- & $x$ & $--\frac{-}{1}$ & --- & --- & --- & --- & --- & --- & --- & --- & -- \\
\hline--- & 1 & 1 & $x$ & $--\overline{0}$ & --- & -- & 4 & $x$ & --- & --- & --- \\
\hline--- & 15 & 7 & 38 & 2 & 1 & --- & 1 & --- & --- & --- & --- \\
\hline--- & --- & $X$ & --- & $* 1$ & --- & --- & $x$ & X & $* 1$ & --- & --- \\
\hline--- & --- & X & --- & --- & --- & --- & --- & 2 & --7 & -- & 3 \\
\hline--- & --- & $X$ & $--\frac{1}{1}$ & --- & --- & --- & 1 & --- & 1 & --- & --- \\
\hline--- & --- & --- & 1 & --- & --- & -- & 1 & -- & --- & 1 & --- \\
\hline--- & --- & -- & $x$ & --- & -- & $x$ & -- & $--n$ & $* 2$ & --- & - - \\
\hline--- & --- & --- & $x$ & $--\frac{-}{1}$ & $--\overline{0}$ & --- & $x$ & 2 & -- & --- & --- \\
\hline--- & --- & --- & --- & 1 & 2 & 1 & --- & $x$ & --- & --- & --- \\
\hline--- & --- & --- & --- & $x$ & --- & -- & --- & --- & --- & --- & -- \\
\hline--- & --- & --- & --- & $x$ & --- & --- & --- & $x$ & $x$ & --- & X \\
\hline--- & --- & --- & --- & --- & $\times$ & --- & --- & $x$ & 1 & --- & --- \\
\hline--- & --- & --- & --- & --- & --- & $x$ & --- & --- & 3 & --- & 1 \\
\hline--- & --- & --- & --- & --- & --- & 10 & --- & --- & --- & --- & --- \\
\hline--- & --- & --- & --- & --- & --- & --- & $X$ & $x$ & --- & --- & --- \\
\hline--- & --- & --- & --- & --- & -- & --- & $x$ & $x$ & --- & --- & --- \\
\hline--- & --- & --- & --- & --- & $-\cdots$ & --- & $x$ & $--\frac{-}{0}$ & --- & $--\bar{T}$ & --- \\
\hline--- & --- & --- & --- & --- & --- & --- & $x$ & 3 & --- & 1 & -- \\
\hline--- & --- & --- & --- & --- & -- & --- & --- & $X$ & --- & --- & --- \\
\hline--- & --- & --- & --- & --- & --- & --- & --- & $x$ & --- & --- & $--\bar{Y}$ \\
\hline--- & --- & --- & --- & --- & --- & --- & --- & X & --- & $x$ & x \\
\hline--- & --- & --- & --- & --- & --- & --- & --- & $x$ & --- & --- & --- \\
\hline--- & --- & --- & --- & --- & --- & --- & --- & 2 & --- & $--\frac{-}{1}$ & \\
\hline--- & --- & --- & --- & --- & --- & --- & --- & $X$ & --- & 1 & 1 \\
\hline--- & --- & --- & --- & --- & --- & --- & --- & $X$ & $--\overline{1}$ & --- & --- \\
\hline--- & --- & --- & --- & --- & --- & --- & --- & $x$ & 1 & --- & --- \\
\hline--- & --- & --- & --- & --- & --- & --- & --- & $\times$ & & --- & --- \\
\hline--- & --- & --- & --- & --- & --- & --- & --- & 2 & 1 & --- & $x$ \\
\hline--- & --- & --- & --- & --- & --- & --- & --- & 1 & $--\overline{7}$ & $--\overline{1}$ & --- \\
\hline--- & -- & --- & --- & --- & --- & --- & --- & -- & 7 & 1 & --- \\
\hline--- & -- & --- & --- & --- & --- & --- & --- & --- & --- & 1 & $--\overline{1}$ \\
\hline--- & --- & --- & --- & -- & $\cdots$ & -- & --- & --- & -- & 8 & $\underline{1}$ \\
\hline 200 & 200 & 200 & 200 & 200 & 200 & 200 & 200 & 200 & 200 & 200 & 200 \\
\hline
\end{tabular}


TABLE 2.-Pollen-spore zones, based on selected taxa from table 1

[Taxon or group numbers and the counts correspond to those in table 1 . Counts divided by $2=$ percentages. $X$ denotes occurrence; asterisk (*) indicates questionable determination ]

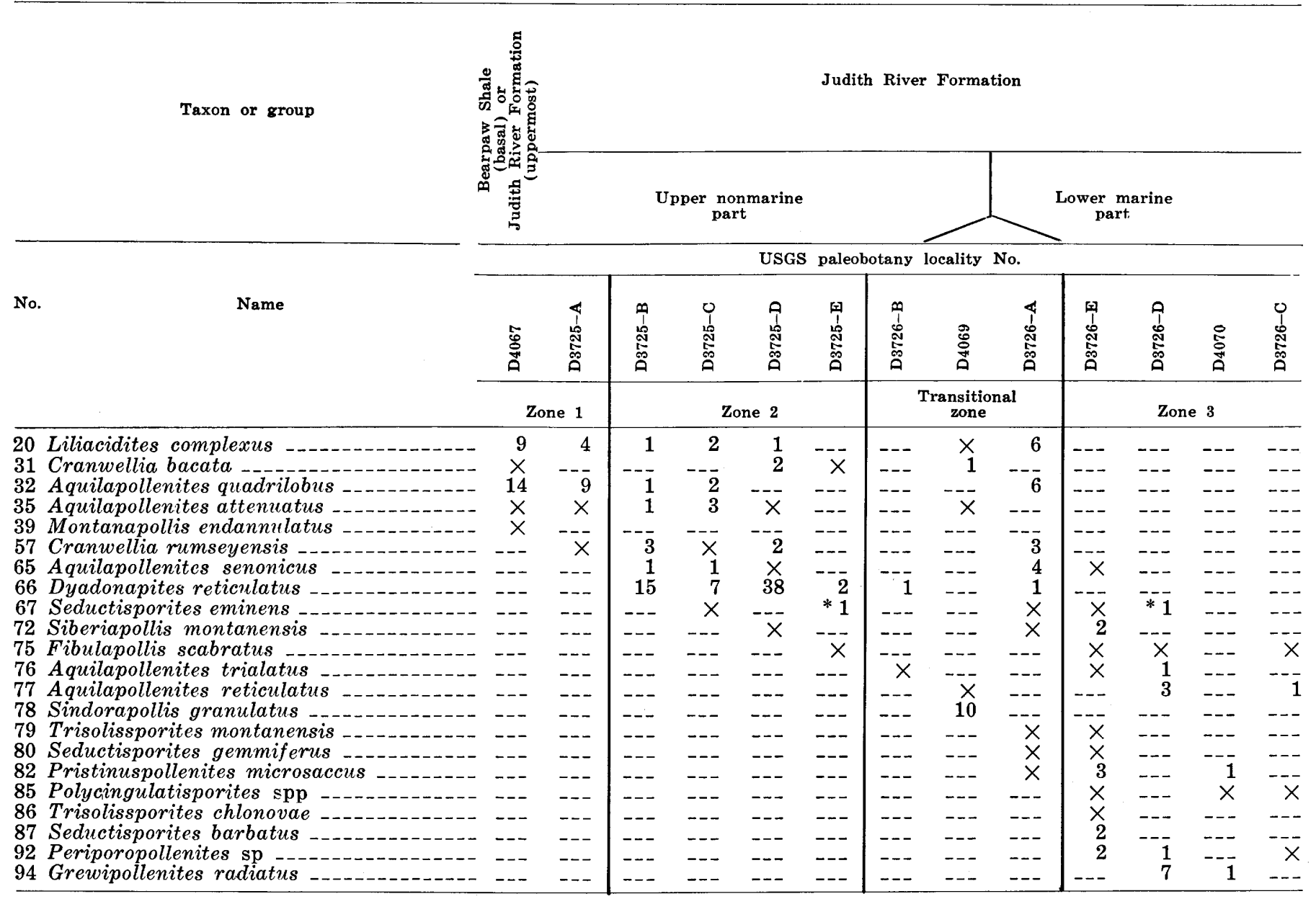

of species in the upper and lower parts of the section.

\section{SYSTEMATICS}

In this section, taxa of species rank are arranged under their appropriate genera. Spore genera are followed by those of pollen. All genera are regarded as form genera. Previously known and described genera and species are redescribed only when the author believes that contributions to the interpretation of the taxa, based on data from the Judith River Formation specimens, can be made.

\section{TRILETES}

\section{Genus CYATHIDITES Couper, 1953}

Cyathidites Couper, 1953, p. 27.

Cyathidites Couper, 1953. In Dettmann, 1963, p. 22.

Type species. - Cyathidites australis Couper, 1953, p. 27, pl. 2, fig. 11 (holotype) ; New Zealand; Ohika beds, Jurassic.

\section{Cyathidites minor Couper, 1953}

Plate 1, figure 1; table 1, No. 1

Cyathidites minor Couper, 1953, p. 28.

Holotype.-In Couper, 1953, p. 28, pl. 2, fig. 13; Ohika beds; New Zealand; Jurassic.

\section{Cyathidites sp.}

Plate 1, figure 2; table 1, No. 83

Genus DELTOIDOSPORA Miner, 1935 emend. Potonie, 1956 Deltoidospora Miner, 1935, p. 618.

Deltoidospora Miner, 1935 emend. Potoniée, 1956, p. 13.

Type species.-(designated by Potonié, 1956, p. 13) Deltoidospora hallii Miner, 1935, p. 618, pl. 24, fig. 7 (lectotype) ; Cascade County, Mont. Kootenai Formation; Early Cretaceous.

\section{Deltoidospora sp.}

Plate 1, figure 3; table 1, No. 2

Genus STEREISPORITES Pflug in Thomson and Pflug, 1953

Sphagnum-sporites Raatz, 1937, p. 9, (No generic description.) 
TABLE-3.-Abundance ratios between two pairs of pollen species in the upper and lower parts of the composite section

[Ratios between total counts of Tricolpites reticulatus plus Tricolpites hians and total counts of Tricolpopollenites levitas plus Tricolpopollenites tessellatus in the three zones and transitional zone (see table 2) showing relative abundance of the two pairs of species in the upper and lower parts of the section Taxa and counts from table 1 . Counts divided by $2=$ percentages]

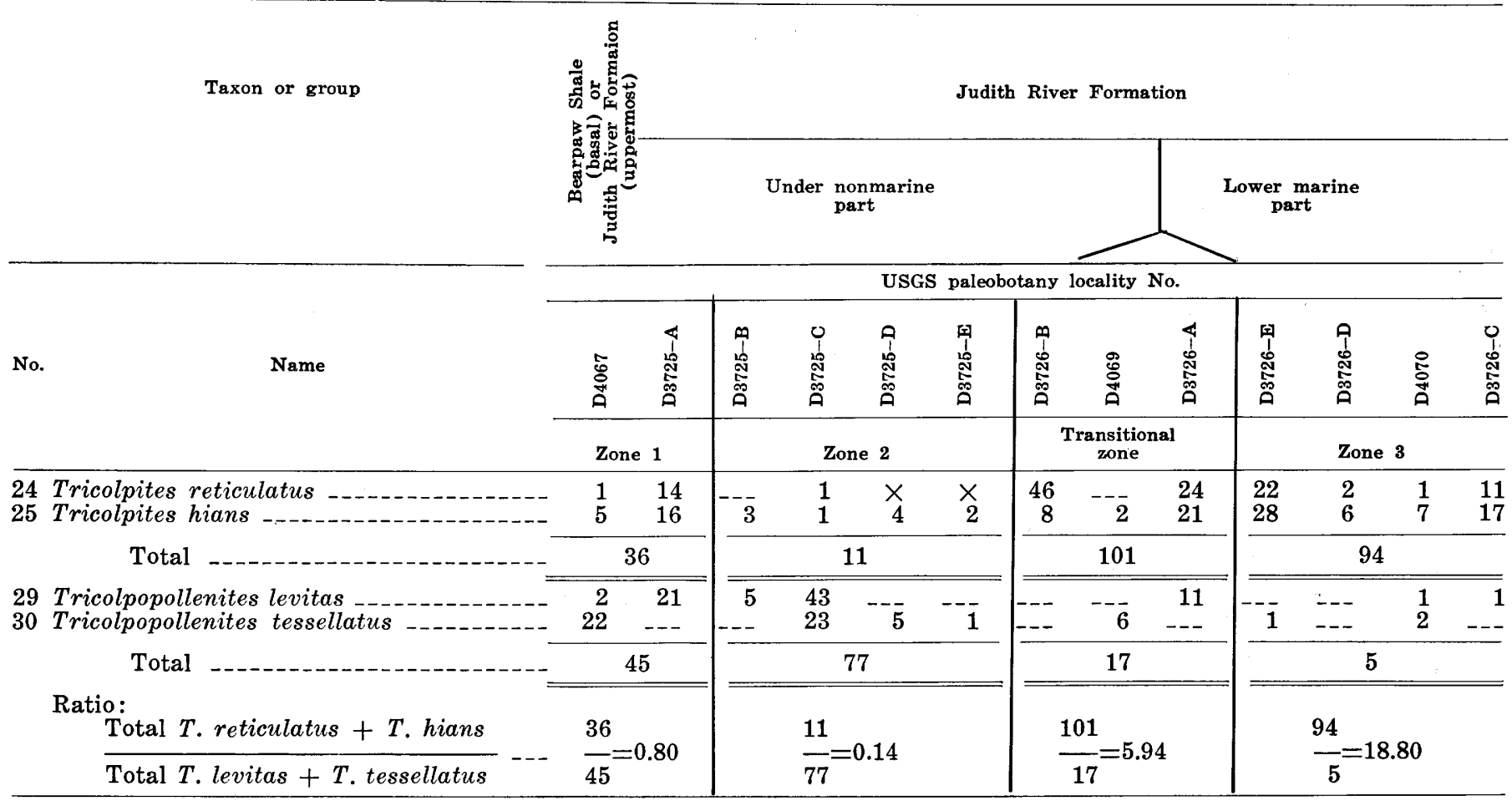

Stereisporites Pflug in Thomson and Pflug, 1953 (March), p. 53.

Sphagnites Cookson, 1953b (October), p. 463.

Sphagnumsporites Raatz, 1937. In Potonié, 1956, p. 17.

Stereisporites Thomson and Pflug, 1953 [March] s. l. In Krutzsch, 1963b, p. 9-20.

Stereisporites Thomson and Pflug, 1953 (March). In Potonié, 1966, p. 19.

Type species.-Stereisporites (Sporites) stereoides (Potonié and Venitz) Thomson and Pflug, 1953, p. 53 (designated by Potonié, 1966, p. 19); lectotype in Potonié and Venitz (1934, p. 11, pl. 1, fig. 4) near Köln, Germany; late Oligocene to Miocene.

Remarks.-Pflug in Thomson and Pflug (1953) was the author of Stereisporites-not Thomson and Pflug (1953) as in Krutzsch (1963b, p. 9) and in Potonié (1966, p. 19). See Thomson and Pflug (1953, p. 53).

\section{Stereisporites spp.}

Plate 1, figure 4, 5; table 1, No. 3

Genus LEPTOLEPIDITES Couper, 1953 emend. Potonié, 1966 Leptolepidites Couper, 1953, p. 28.

Leptolepidites Couper, 1953 emend. Potonié, 1966, p. 30.

Type species.-Leptolepidites verrucatus Couper, 1953, p. 28, pl. 2, fig. 14 (holotype); New Zealand; Ohika beds; Jurassic.

\section{Leptolepidites major Couper, 1958}

Plate 1, figure 6 ; table 1, No. 4

Leptolepidites major Couper, 1958, p. 141.

Holotype.-In Couper, 1958, p. 141, pl. 21, fig. 7 ; Yorkshire, England; Sycarham Beds; Middle Jurassic.

Leptolepidites cf. L. major

Plate 1, figure 7; table 1 , No. 4

Genus BACULATISPORITES Pflug and Thomson in Thomson and Pflug, 1953

Baculatisporites Pflug and Thomson in Thomson and Pflug, 1953 , p. 56.

Baculatisporites Thomson and Pflug, 1953. In Potonié, 1956, p. 33.

Baculatisporites Thomson and Pflug, 1953. In Dettmann, 1963 , p. 34.

Type species.-Baculatisporites primarius (Wolff) Thomson and Pflug, 1953, p. 56; holotype in Wolff, 1934, p. 66, pl. 5, fig. 8; near Dettingen, Germany; Pliocene.

\section{Baculatisporites sp.}

Plate 1, figure 8; tạble 1, No. 64

Genus OSMUNDACIDITES Couper, 1953

Osmundacidites Couper, 1953, p. 20.

Osmundacidites Couper, 1953. In Potonié, 1956, p. 30-31.

Conosmundasporites Klaus, 1960, p. 127-129. 
Osmundacidites Couper, 1953. In Dettmann, 1963, p. 31-32. Osmundacidites Couper, 1953. In Potonié, 1966, p. 36.

Type species.-Osmundacidites wellmanii Couper, 1953, p. 20, pl. 1, fig. 5 (holotype) ; New Zealand; Ohika beds; Middle Jurassic. Holotype also illustrated in Couper, 1960, pl. 1, fig. 1.

\section{Osmundacidites sp.}

Plate 1, figure 9; table 1, No. 73

Genus KUYLISPORITES Potonié, 1956

Kuylisporites Potonié, 1956, p. 38.

Type species.-Kuylisporites waterbolki Potonié, 1956 , p. 38. Illustrated in Kuyl, Muller, and Waterbolk, 1955, pl. 1, fig. 7 (holotype) ; Trinidad, West Indies; late Tertiary.

\section{Kuylisporites spp.}

Plate 1, figures 10,11 ; table 1 , No. 6

Genus ISCHYOSPORITES Balme, 1957

Ischyosporites Balme, 1957, p. 23.

Ischyosporites Balme, 1957. In oPtonié, 1960, p. 46.

Type species.-Ischyosporites crateris Balme, 1957, p. 23-24, pl. 3, fig. 45 (holotype) ; Western Australia; ?Neocomian-early. Aptian.

Ischyosporites punctatus Cookson and Dettman, 1958

Ischyosporites punctatus Cookson and Dettmann, 1958, p. 104. Holotype.-In Cookson and Dettman, 1958, p. 104, pl. XVI, fig. 1; South Australia; Early Cretaceous.

Ischyosporites of. I. punctatus

Plate 1, figure 12; table 1, No. 74

Genus CICATRICOSISPROITES Potonié and Gelletich, 1933 emend. Potonié, 1966

Cicatricosi-sporites Potonié and Gelletich, 1933, p. 522.

Cicatricosisporites Potonié and Gelletich, 1933. In Potonié, 1956 , p. $47-48$.

Cicatricosisporites Potonié and Gelletich, 1933 emend. Potonié, 1966 , p. 58.

Type species.-Cicatricosisporites dorogensis Potonié and Gelletich, 1933, p. 522, pl. 1, fig. 1 (lectotype, designated by Potonié, 1956, p. 47) ; Dorog, Ungarn, Germany; late Paleocene to Eocene.

Cicatricosisporites stoveri Pocock, 1964

Plate 1, figure 13; table 1, No. 84

Cicatricosisporites stoveri Pocock, 1964, p. 161.

Holotype.-In Pocock, 1964, p. 161, pl. 2, figs. 24, 25; Saskatoon area, Saskatchewan, Canada; Upper part, Mannville Group; middle Albian.

\section{Cicatricosisporites sp.}

Plate 1, figure 14; table 1, No. 45

Cicatricosisporites radiatus Krutzsch, 1959b

Plate 1, figures 15,16 ; table 1 , No. 7
Cicatricosisporites radiatus Krutzsch, 1959b, p. 126-127.

Anemia radiata (Krutzsch) Stanley, 1965, p. 258-259, pl. 33, figs. 6, 7; South Dakota; Paleocene.

Holotype.-Illustrated in Krutzsch, 1957, pl. 1, figs. 41, 42; middle Europe; late Oligocene or early Miocene.

Genus GHOSHISPORA Srivastava, 1966 sensu Leffingwell, 1971

Ghoshispora Srivastava, 1966, p. 511.

Styx Norton in Norton and Hall, 1967, p. 104.

Ghoshispora Srivastava, 1966. In Leffingwell, 1971, p. 24.

Type species.-Ghoshispora scollardiana Srivastava, 1966, p. 511-512, pl. II, fig. 9 (holotype) ; Scollard, Alberta, Canada; Edmonton Formation (upper part) ; late Maestrichtian.

\section{Ghosispora sp.}

Plate 1, figure $17(\times 500)$; table 1 , No. 8

\section{Genus FORAMINISPORIS Krutzsch, 1959a}

Foraminisporis Krutzsch, 1959a, p. 130.

Foraminisporis Krutzsch, 1959. In Dettmann, 1963, p. 71. Foraminisporis Krutzsch, April 1959. In Potonié, 1966, p. 35. Foraminisporis Krutzsch, 1959b. In Krutzsch, 1963a, p. 2.

Type species. - Foraminisporis foraminis Krutzsch, 1959a, p. 130, pl. XIX, figs. 203-206 (holotype, four levels); Geiseltal, Germany; Eocene.

Foraminisporis wonthaggiensis (Cookson and Dettman, 1958) Dettman, 1963 Plate 2, figures 1,2 ; table 1, No. 5

Apiculatisporis wonthaggiensis Cookson and Dettmann, 1958, p. 100.

Foraminisporis wonthaggiensis (Cookson and Dettman) Dettmann, 1963 , p. 71 , pl. XIV, figs. 19-23; southeastern Australia; late-Mesozoic.

Foraminisporis wonthaggiensis (Cookson and Dettman) Dettmann. In Norris, 1967, p. 98, pl. 13, fig. 23; central Alberta, Canada; lower part, Colorado Group; Albian?Cenomanian.

Holotype.-In Cookson and Dettmann, 1958, p. 100, pl. XIV, fig. 8; Wonthaggi State Coal Mine area, Victoria, eastern Australia; Early Cretaceous.

Genus POLYCINGULATISPORITES Simoncsics and Kedves, 1961 emend. Playford and Dettmann, 1965

Polycingulatisporites Simoncsics and Kedves, 1961, p. 34. Polycingulatisporites Simonesics and Kedves, 1961 emend. Playford and Dettmann, 1965, p. 143-144.

Type species.-Polycingulatisporites circulus Simoncsics and Kedves, 1961, p. 34, pl. VI, figs. 1-6; Hungary; Early Cretaceous.

\section{Polycingulatisporites spp.}

Plate 2, figures 3-5; table 1, No. 85

Genus TRISOLISSPORITES n. gen.

Type species. - Trisolissporites montanensis $n$. sp., USGS paleobotany locality D3726-E, slide (3) at $99.3 \times 11.3$; plate 2 , figures 6,7 (holotype, two 
levels), center NE1/4, sec. 31, T. 23 N., R. 17 E.; Fergus County, Mont.; Judith River Formation (lower marine part); late Campanian.

Description. - Trilete miospores with narrow equatorial cingulum. Equatorial outline round, rounded triangular, or slightly irregular. Trilete mark distinct, with or without margines. Rays of trilete long, reaching to or almost to equator of spore. Proximal surface ornamented with three sunburst or daisylike configurations located in the three sectors partitioned off by the three rays of the trilete mark-each sunburst configuration completely occupying its tripartite sector of the proximal surface of the spore. Distal surface ornamented with thickenings-these of various sizes and shapes, randomly arranged or zonate.

Remarks.-This new genus has been erected to accommodate a group of exotic trilete spores having in common three sunburstlike configurations on the proximal surfaces. Chlonova $(1960$, p. 37) remarked that some unique spores which she described, and which I have transferred to this genus, probably deserve separation into a special morphological genus. She referred to her species as the three-sun spores; hence, I selected the name Trisolissporites for this genus.

New combinations.-The following species conform to the new genus Trisolissporites and are here transferred to it.

Trisolissporites (Stenozonotriletes) radiatus (Chlonova, 1960, p. 36-37, pl. IV, figs. 22-23; Chulimo-Yenisei depression; Cenomanian-Turonian) n. comb.

Trisolissporites (Stenozonotriletes) stellatus (Chlonova, 1960, p. 38, pl. IV, fig. 25; ChulimoYenisei depression; Cenomanian-Turonian) $n$. comb.

Trisolissporites (Taurocusporites) radiatus (Chlonova) (Krutzsch, 1963b, p. 20) n. comb.

Trisolissporites (Taurocusporites) stellatus (Chlonova) (Krutzsch, 1963b, p. 20) n. comb.

Trisolissporites (Dulhuntyispora? minuta) minutus (Jansonius, 1962, p. 48-49, pl. 11, figs. 1, 2; western Canada; Early Triassic) n. comb.

Trisolissporites (Taurocusporites) chlonovae (Döring, 1966, p. 105-106, pl. I, figs. 7-9 ; Brandenburg, Germany; Wealden) n. comb.

Comparison with other genera.-Potonié (1966, p. 43) suggested that the spores (Stenozonotriletes radiatus and Stenozonotriletes stellatus) which Chlonova (1962, p. 300, pl. 1, figs. 2-4) illustrated could perhaps be placed in Dulhuntyispora. Trisolissporites superficially resembles the Australian Permian genus Dulhuntyispora Potonié (1956, p. 37-38) but is easily distinguishable because its interradial ornaments are on the proximal surface of the spore and are not inflations of the outer wall layer, whereas the interradial ornaments of Dulhuntyispora are equatorially to subequatorially located and appear as domelike inflations or blisters-the wall of the scutula being distinctly detached from the lower wall layer or layers of the spore. (See Dulhuntyispora dulhuntyi, pl. 2, fig. 11.)

The radiating proximal ornamentations and the distal ornamentation of Trisolissporites easily separate it from Stenozonotriletes Naumova ex Naumova emend. Potonié (1958, p. 25) whose exine was described by Potonié as smooth to chagranate ("glatt bis chagrinat").

Trisolissporites is separable from Taurocusporites Stover (1962 emend. Playford and Dettmann, 1965, p. 146) by its three daisylike proximal interradial ornaments. Zonate concentric thickenings are present in some species of Trisolissporites but are not the essential features that they are for Taurocusporites. The proximal ornamentation of Trisolissporites extends to the equator of the spore whereas the equatorial area of the proximal surface of Taurocusporites segmentatus, the type species of Taurocusporites, is usually unornamented or has only a few scattered verrucae.

Trisolissporites montanensis n. sp.

Plate 2, figures 6-10; table 1, No. 79

Holotype.-USGS paleobotany locality D3726-E, slide (3) at $99.3 \times 11.3$; plate 2 , figures 6,7 (two levels), center NE1/4 sec. 31, T, 23 N., R 17 E.; Fergus County, Mont.; Judith River Formation (lower marine part) ; late Campanian.

Paratype.-USGS paleobotany locality D3726-E, slide (2) at $81.8 \times 11.2$, plate 2 , figure 8 ; same locality data as for holotype.

Description - (based on eight specimens).-Cingulate, trilete miospores. Equatorial outline in polar view circular, rounded triangular, or slightly irregular. Some specimens having slight equatorial indentations in cingulum adjacent to ends of trilete rays. Equatorial diameter $35 \mu-49 \mu$. Equatorial cingulum $3 \mu-4 \mu$ wide. Rays of trilete mark reaching approximately to inner margin of cingulum; in some specimens rays bifurcating near their radial extremities and branches thence appearing to merge with inner margin of cingulum. Proximal surface ornamented with three sunburst or daisylike configurations located in the three sectors set apart by the three rays of the trilete mark. Centers of configurations located at approximate centers of the three sectors of the proximal surface. Rays of each configuration 
15-25 in number, consisting of thickenings of exine -these arranged to resemble the ray flowers of daisies. Center part of configurations circular to irregular in shape, devoid of exinal thickenings, approximately $5_{\mu}$ in diameter. Distal surface ornamented with flat, randomly arranged, oval, round, or irregular exinal thickenings $3 \mu-7 \mu$ in diameter and $1 \mu-3 \mu$ apart.

Comparison.-The proximal surface of $T$. montanensis $\mathrm{n}$. sp. seems to be indistinguishable from that of $T$. radiatus (Chlonova) $n$. comb., but the distal surface of $T$. montanensis is ornamented with numerous flat randomly arranged round to slightly irregular thickenings, whereas the distal surface of $S$. radiatus, according to Chlonova $(1960$, p. 37$)$, always has concentric solid or broken narrow ridges. Chlonova's diagram (1962, fig. 2b) of the distal side of her Stenozonotriletes radiatus shows a concentric arrangement of the distal thickenings; and photographs of additional spores from the Turonian of Western Siberia that were identified as $S$. radiatus Chlonova also show a ringlike thickening (see Skuratenko, 1966, pl. II, fig. 3 and Samoilovitch and others, 1961, pl. XLII, figs. 5-7). T. radiatus and $T$. montanensis are probably from closely related plants, but the two species are easily distinguishable because of the different configuration of their distal thickenings.

$T$. montanensis $\mathrm{n}$. $\mathrm{sp}$. is easily distinguishable from $T$. stellatus (Chlonova) n. comb and T. chlonovae (Döring) n. comb. by its coarser proximal ornamentation.

$T$. montanensis $\mathrm{n}$. sp. is larger than $T$. minutus (Jansonius) n. comb. and lacks the ringlike distal thickenings that distinguish $I$. minutus.

Trisolissporites chlonovae (Döring, 1966) n. comb.

Plate 2, figure 12-14; table 1, No. 86

Taurocusporites chlonovae Döring, 1966, p. 105-106.

Holotype.-In Döring, 1966, p. 105-106, pl. I, figs. 7-9; Brandenburg, Germany; Wealden, Early Cretaceous.

Description (based on 13 specimens from USGS paleobotany locality D3726-E).-Cingulate, trilete miospores. Equatorial outline in polar view circular or nearly so. Equatorial diameter $37 \mu-56 \mu$. Equatorial cingulum $2 \mu-5 \mu$ wide. Trilete mark distinct; margines $1 \mu-2 \mu$ wide, in some specimens not clearly visible; rays extending to or almost to equator, in some specimens rays appearing to bifurcate near their radial extremities. Proximal surface of spore ornamented with numerous microverrucae, verrucae, and elongate thickenings - these alined toward a central point to form three starlike configurations whose centers are located approximately at the center of each of the three sectors set off by the three rays of the trilete mark. Individual microverrucae and verrucae of the starlike configurations $0.5 \mu-1 \mu$ in diameter, elongate thickenings $0.5 \mu-1 \mu$ wide and as much as $5 \mu$ long. Distal surface of spore ornamented with circular to very irregular exinal thickenings $1 \mu-9 \mu$ in diameter and of low relief; distal thickenings numerous on some specimens, sparse on others, randomly arranged, not arranged to form concentric zones.

Remarks.-I transferred Taurocusporites chlonovae Döring to Trisolissporites because of the three sunburstlike configurations on its proximal surface. Döring placed this species in Taurocusporites but in his description did not mention zonate thickenings on its distal surface, and if these thickenings are not present the species does not conform to Taurocusporites. In assigning my specimens to the species $T$. chlonovae, I am assuming that $T$. chlonovae does not have a zonate distal surface.

$T$. chlonovae is possibly synonymous with $T$. stellatus (Chlonova) $\mathrm{n}$. comb. Drawings rather than photographs ilustrated the holotype of $T$. stellatus and do not clearly show the characteristics of the species.

$T$. chlonovae is easily differentiated from $T$. radiatus and from $T$. montanensis because of its much smaller and more numerous proximal exinal thickenings that make up the three sunburst configurations.

\section{Genus GLEICHENIIDITES Ross, 1949 emend. Skarby, 1964}

Gleicheniidites Ross, 1949, p. 31-32. (Valid name, monotypic.) Gleicheniidites Ross, 1949. In Delcourt and Sprumont, 1955, p. 26.

Gleicheniidites (Ross, 1949) Delcourt and Sprumont, 1955. In Potonié, 1956, p. 14-15.

Triremisporites Delcourt and Sprumont, 1957, 61-63.

[in part] Gleicheniidites (Ross, 1949) Delcourt and Sprumont, 1955, emend. Delcourt and Sprumont, 1959, p. 34. (Included spores having continuous equatorial thickening of wall.)

[in part] Gleicheniidites Ross, 1949 emend. Krutzsch, 1959a, p. 109-115. (Included ornamented spores.)

[not] Gleicheniidites Grigorjeva in Samoilovitch and others, 1961 , p. 59-60. (Later homonym of Gleicheniidites Ross, 1949.)

Fasciatisporites Sato, 1961, p. 85.

Gleicheniidites Ross ex Delcourt and Sprumont emend. Dettmann, 1963, p. 64-65.

Gleicheniidites Ross, 1949 emend. Skarby, 1964, p. 60-65.

Type species. - Gleicheniidites senonicus Ross, 1949, p. 31-32, pl. I, fig. 3 (holotype) ; Asen, Scania, Sweden; late Santonian or early Campanian. 
Gleicheniidites spp.

Plate 3, figures 1-4; table 1, No. 9

Genus Camarozonosporites Pant ex Potonié, 1956 emend. Klaus, 1960

Camarozonosporites Pant, 1954, p. 51. (Genus described but no species assigned.)

Camarozonosporites Pant, 1954 ex Potonié, 1956, p. 65.

Hamulatisporis Krutzsch, 1959a, p. 157-158.

Camerozonosporites Pant, 1954 ex Potonié, 1956. In Krutzsch, 1959a, p. $186-187$.

Camarozonosporites Potonié, 1956 emend. Klaus, 1960, p. 135-136.

Camarozonosporites Pant, 1954 ex Potonié, 1956. In Krutzsch, 1963a, p. 18, 20-23.

Camarozonosporites (Pant ex Potonié, 1956) Klaus, 1960. In Potonié, 1966, p. 92.

Camarozonosporites (Potonié, 1956) Klaus, 1960. In Hedlund, 1966, p. 17.

Type species.-Camarozonosporites (Rotaspora) cretaceus (Weyland and Krieger, 1953) Potonié, 1956, p. 65 ; holotype in Weyland and Krieger, 1953, p. 12, pl. 3, fig. 27; Aachen, Basiston, Germany; middle Senonian.

Camarozonosporites spp.

Plate 3, figures 5, 6; table 1, No. 10 MONOLETES

Genus LAEVIGATOSPORITES Ibrahim, 1933 emend. Schopf, Wilson, and Bentall, 1944

Laevigato-sporites Ibrahim, 1933, p. 39.

Polypodium-sporites Raatz, 1937, p. 10.

Polypodiaceae-sporites Thiergart, 1937, p. 297.

Phaseolites Wilson and Coe, 1940, p. 182.

Laevigato-sporites Ibrahim, 1933 emend. Schopf, Wilson, and Bentall, 1944, p. 36-37.

Type species.-Laevigatosporites vulgaris (Ibrahim) Ibrahim, 1933, p. 39-40; holotype in Ibrahim, 1932, p. 448, pl. XV, fig. 16; Westfal, Germany; Carboniferous.

\section{Laevigatosporites spp.}

Plate 3, figures 7, 8; table 1, No. 12

Genus UMBOSPORITES Newman, 1965

Umbosporites Newman, 1965, p. 10.

Type species.-Umbosporites callosus Newman, 1965, p. 10 ; pl. 1, fig. 2 (holotype) ; northwestern Colorado; basal Iles Formation; Campanian.

Umbosporites callosus Newman, 1965

Plate 3, figures 9, 10; table 1, No. 13

Genus MICROFOVEOLATOSPORIS Krutzsch, 1959a

Microfoveolatosporis Krutzsch, 1959a, p. 211.

Type species.-Microfoveolatosporis pseudodentatus Krutzsch, 1959a, p. 212, pl. 41, fig. 463 (holotype); Geiseltal, Germany; Eocene.
Microfoveolatosporis canaliculatus Dettmann, 1963

Plate 3, figure 11; table 1, No. 1

Microfoveolatosporis canaliculatus Dettman, 1963, p. 87.

Holotype.-In Dettmann, 1963, p. 87, pl. XIX, figs. 15, 16; South Australia; Tambo Formation; Albian.

\section{ZONATES}

Genus SEDUCTISPORITES Chlonova, 1961

Seductisporites Chlonova, 1961, p. 56-57.

Seductisporites Chlonova, 1961. In Potonié, 1966, p. 96.

Type species.-Seductisporites signifer Chlonova, 1961, p. 56-57, pl. VII, fig. 44 (holotype) ; mouth of Vakh River, western Siberian lowlands; Maestrichtian-Danian.

Description.-Inaperturate miospores having a thin outer wall layer which forms a zone at equator. Shape of spores in polar view circular to rounded triangular. Equatorial zona (flange) narrow or as much as $9 \mu$ wide. Outer wall layer membranous or as much as $1.5 \mu$ thick. Zona distinct and complete, or fragmentary, or almost lacking. Fragmentary or indistinct tetrad mark present in some specimens and species; when present, with or without thickened margins. Distal hemisphere of spore ornamented with simple, bifurcating, or netlike muroidal ridges or folds. Proximal hemisphere smooth or variously ornamented but differing from distal hemisphere. (Inasmuch as specimens that have fragmentary tetrad marks have their muroidal ridges on the distal hemisphere, it is assumed by analogy that specimens that lack tetrad marks also have their muroidal ridges on the distal side.)

Comparison with similar genera.-Rouseisporites Pocock (1962, p. 52-53) differs from Seductisporites in that its zonate layer has invaginations in each radial region at the equator. (See Dettmann, 1963, p. 96.)

Zlivisporis Pacltova (1961, p. 86-87) differs from Seductisporites in that it has a distinct trilete mark which reaches to the equator.

The anastomosing folds of the perisporal layer of the Triassic genus Peroaletes Bharadwaj and Singh (1964, p. 38-39) have slight resemblance to the muroidal folds on the distal hemispheres of Seductisporites, Zlivisporis, and Rouseisporites; however, the two hemispheres of Peroaletes are apparently similarly ornamented and are not distinctly different from each other as they are in Seductisporites, Zlivisporis, and Rouseisporites.

Seductisporites gemmiferus n. sp.

Plate 3, figures 12-17; table 1, No. 80

Holotype._USGS paleobotany locality D3726-A, 
slide (2) at $96.7 \times 19.8$; plate 3 , figures 12,13 , center NE1/4 sec. 31, T. 23 N., R. 17 E.; Fergus County, Mont.; Judith River Formation; late Campanian.

Paratype.-USGS paleobotany locality D3726-A, slide (1) at $91.4 \times 14.1$; plate 3 , figuies 14,15 ; same locality data as for holotype.

Paratype.-USGS paleobotany locality D3726-A, slide $(2)$ at $92.4 \times 18.3$; plate 3 , figures 16,17 ; same locality data as for holotype.

Description (based on 20 specimens).--Inaperturate miospores. Shape in polar view round, rounded triangular, or irregular owing to folding of the delicate outer wall layer. Spores consisting of a central body and a thin-walled outer layer which forms a zone at the equator. Wall of central cell $1 \mu-2 \mu$ thick. Equatorial diameter of central body $42 \mu-59 \mu$, of outer layer $48 \mu-70 \mu$; zone extending $1 \mu-7 \mu$ beyond equator of central body. Width of zone in individual specimens nearly constant (pl. 3, fig. 16) or variable (pl. 3, fig. 12). Fragmentary tetrad mark present in some specimens; when present, raised, cordlike, contorted, sparingly warty. Surface of outer layer smooth to finely scabrate; distal surface having three to six radially oriented, raised, knifelike ridges or folds - these more or less perpendicular to surface, $2 \mu-4 \mu$ high, decreasing in height at outer ends, in some places bifurcating; in most specimens folds not extending as far as equator of central cell. Proximal surface of central cell ornamented with scattered, nearly spherical $(1 \mu-4 \mu$ in diameter) wartlike projections or gemmae.

Remarks.-This species was given the name gemmiferus (gemmifer, bearing or producing gems) because its proximal hemisphere is conspicuously adorned with small protrusions.

Comparison with similar species.-The configuration of the ridges on the distal surface of S. gemmiferus resembles that of the muroidal ridges of Rouseisporites radiatus Dettmann (1963, p. 98, pl. XXIII, figs. 13-17) ; however, the two species are distinctly different because the zona of $S$. gemmiferus is wider than that of $R$. radiatus, S. gemmiferus does not have conical invaginations in the radial regions at the equator, and $S$. gemmiferus is ornamented on the proximal side, whereas $R$. radiatus is smooth.

S. gemmiferus is separable from Seductisporites signifer because of the distinct wartlike ornamentation on its proximal hemisphere.

$S$. gemmiferus lacks the flask-shaped equatorial invaginations that characterize Rouseisporites granospeciosus (Delcourt and Sprumont) Delcourt, Dettmann, and Hughes (1963, p. 291) ; and the wart- like ornamentation on the proximal surface of the central body of $S$. gemmiferus also distinguishes it from $R$. granospeciosus which has a smooth proximal surface.

S. gemmiferus n. sp. differs from S. barbatus $\mathrm{n}$. sp. because of its distinctly different proximal ornamentation and its less fragile equatorial zone.

\section{Seductisporites eminens n. sp. \\ Plate 4, figures 1-3; table 1, No. 67}

[not] Lycopodium novomexicanum Anderson, 1960, p. 14-15, pl. 1, fig. 2.

Lycopodiumsporites novomexicanum (Anderson) Drugg, 1967, p. 40 , pl. 6, fig. 27.

Holotype.-USGS paleobotany locality D3726-E; slide (5) at $99.0 \times 10.3$; plate 4 , figure 1 ; center NE1/4 sec. 31, T. 23 N., R. 17 E.; Fergus County, Mont.; Judith River Formation (lower marine part) ; late Campanian.

Paratype.-USGS paleobotany locality D3726-E, slide (9) at $84.8 \times 16.1$; plate 4 , figure 2 ; same locality data as for holotype.

Paratype.-USGS paleobotany locality D3726-E, slide (8) at $109.2 \times 19.7$; plate 4 , figure 3 ; same locality data as for holotype.

Description (based on 15 specimens, all in polar view).-Inaperturate miospores. Shape in polar view rounded triangular. Equatorial diameter $52 \mu-73 \mu$. Tetrad mark when present contorted, in most specimens fragmentary, in some branching, with thickened margins approximately $1 \mu$ wide. Spore having two conspicuous wall layers ; inner layer $1 \mu-2 \mu$ thick, scabrate, confining inner cell; outer layer $0.5 \mu-1.5 \mu$ thick, enveloping inner cell and forming zona at equator. Equatorial zona narrow $(1 \mu-3 \mu$ wide) in interangular areas, wider (as much as $7 \mu$ wide) at angles. Distal surface ornamented with muroidal folds which form a coarse reticulum; muri approximately $1 \mu$ in height, undulating; lumina irregular in shape, $8 \mu-15 \mu$ in diameter; reticulum not extending beyond equator of central cell. Proximal surface smooth to scabrate.

Remarks.-This species was given the name eminens (standing out, eminent) because of the conspicuous muroidal folds on its distal surface.

Comparison with similar species.-A specimen from the Maestrichtian of Escarpado Canyon, Calif., which Drugg (1967, p. 40, pl. 6, fig. 27) identified as Lycopodiumsporites novomexicanum (Anderson) Drugg, seems to be the same as the new species described above. However, Seductisporites eminens seems to be different from Lycopodium novomexicanum Anderson (1960, p. 14-15, pl. 1, fig. 2). Anderson stated that the body of $L$. novomexicanum 
is bordered equatorially by a thin irregular flange, with thickened extensions of the faint laesurae projecting into the flange on many specimens; whereas, the equatorial flange of $S$. eminens $n$. sp. is narrow but not very thin walled or irregular, and laesurae have not been seen to extend into the flange.

S. eminens, in common with Rouseisporites laevigatus Pocock (1962, p. 53-54, pl. 7, fig. 106), has a flange that is wider at the apices (angles), but it differs from $R$. laevigatus in that it has a very distinct distal reticulum and does not have structures resembling pores at the apices.

Its smooth to scabrate proximal surface and its lack of porelike apical structures easily distinguishes $S$. eminens from Rouseisporites reticulatus Pocock (1962, p. 53, pl. 7, fig. 101).

The distal reticulum of $S$. eminens resembles that of Zlivisporis blanensis Pacltova (1961, p. 87, pl. II, figs. 1-4) but $S$. eminens is separable from $Z$. blanensis because of its thicker wall, its zona which is wider at the angles, and by its lack of a distinct Y-mark which extends to the equator.

\section{Seductisporites barbatus n. sp. \\ Plate 4, figures 4-7; table 1, No. 87}

Holotype.-USGS paleobotany locality D3726-E, slide (9) at $111.3 \times 3.2$; plate 4 , figure 4 ; center NE1/4 sec. 31, T. 23 N., R. 17 E.; Fergus County, Mont.; Judith River Formation (lower marine part); late Campanian.

Paratype.-USGS paleobotany locality D3726-E, slide (7) at $82.0 \times 12.5$; plate 4 , figure 5 ; same locality data as for holotype.

Paratype.-USGS paleobotany locality D3726-E, slide (10) at $94.5 \times 7.7$; plate 4 , figures 6,7 ; same locality data as for holotype.

Description (based on 35 specimens).-Alete miospores having an outer wall layer which forms a zone at the equator. Outer wall membranous, delicate, slightly larger than central body, forming a narrow zone $\left(1_{\mu-3 \mu}\right.$ wide) at equator. In some specimens, zone fragmentary or completely lacking. Outline of spore in polar view round, rounded triangular, or irregular owing to folding or distortion. Diameter of central cell $49 \mu-76 \mu$; polar axis apparently shorter than equatorial diameter (judged from two specimens seen in equatorial view). Wall of central cell $1.5 \mu-2 \mu$ thick, outer wall layer thin. No trilete mark evident in any of the 35 specimens examined. One hemisphere (distal?) of spore ornamented with muroidal ridges-these apparently composed of folds of the membranous outer wall layer; configuration of muroidal ridges varying from (1) a few ridges with no definite pattern, to
(2) a pseudo Y-mark with bifurcating rays, to (3) a more complex pattern of bifurcating ridges that join to form a very coarse more or less complete reticulum. Muri $1 \mu-2 \mu$ high and lumina (where present) $15 \mu-30 \mu$ in greatest diameter. Opposite hemisphere (proximal?) ornamented with short $(1 \mu-3 \mu)$ spines or hairlike projections.

Observations have not yet proved whether the outer wall layer completely envelops the spinose hemisphere of the spore.

Remarks.-This species was given the name barbatus (barbatus, bearded) because of its bristly or bearded proximal(?) ornamentation.

Comparison with similar species.-The narrow membranous equatorial zone and the configuration of the muroidal ridges on one hemisphere (of some specimens) of $S$. barbatus n. sp. resemble those of Zlivisporis blanensis Pacltova (1961, p. 87, pl. II, figs. 1-4), but $S$. barbatus differs by not having a Y-mark and by having fine spines or hairlike projections on one hemisphere.

The narrow equatorial zone and the configuration of the muroidal ridges of $S$. barbatus also resemble those of Rouseisporites reticulatus Pocock (1962, p. 53, pl. 7, fig. 101) and Rouseisporites radiatus Dettmann (1963, p. 98, pl. XXIII, figs. 13-17), but $S$. barbatus lacks the conical invaginations in the radial regions at the equator that characterize the other two species. The fine hairlike projections on one hemisphere of $S$. barbatus also distinguish it from $R$. reticulatus and $R$. radiatus.

$S$. barbatus n. sp. differs from S. gemmiferus n. sp. by its distinctly different ornamentation and by its more fragile equatorial zone.

Genus ZONALAPOLlenites Pflug in Thomson and Pflug, 1953

Tsugae-pollenites. In Potonié and Venitz, 1934, p. 17.

Zonalapollenites Pflug in Thomson and Pflug, 1953, p. 66.

Tsugaepollenites Potonié and Venitz, 1934. In Potonié, 1958, p. 48.

Tsugaepollenites Potonié and Venitz, 1934. In Jansonius, 1962, p. 51.

Tsugaepollenites Potonié and Venitz emend. Potonié. In Manum, 1962, p. 45.

Tsugaepollenites Potonié and Venitz emend. Potonié, 1958. In Dettmann, 1963, p. 99.

Tsugaepollenites (Potonié and Venitz, 1934) Potonié, 1958. In Potonié, 1966, p. 117.

Zonalapollenites Pflug (in Thomson and Pflug). In Pocock, 1968, p. 640.

Tsugaepollenites Potonié and Venitz, 1934. In Potonié, 1970, p. 72.

Type species.-Zonalapollenites (Sporonites) igniculus (Potonié) Thomson and Pflug 1953; holotype in Potonié, 1931d, p. 556, fig. 2; near Köln, Germany; Miocene. 
Remarks.-Potonié (1931d, p. 556) described, by means of symbols, and illustrated the new species Sporonites igniculus. Sporonites Potonié had earlier been introduced (Potonié, 1931c, p. 1) as an artificial genus (Gattung) for the provisional grouping of spores.

In Potonié and Venitz (1934, p. 17), "Tsugaepollenites igniculus R. Pot." was introduced and described. The name Tsugae-pollenites was not there validated under the provision of a combined generic and specific description (see Lanjouw and others, 1966, art. 42) because the species name igniculus was not new.

Pflug (in Thomson and Pflug, 1953, p. 66) described the new genus Zonalapollenites. In the same report, Sporonites igniculus Potonié was transferred to Zonalapollenites, and $Z$. igniculus was described. Pflug did not designate a type species for $Z$ onalapollenites but according to artice PB. 4 (Lanjouw and others, 1952) which was in effect at that time "The type of a genus of fossil plants is the first described species which shows such characters as are necessary for distinguishing the genus from other taxa." Zonalapollenites igniculus met the requirements of article PB. 4 and hence became the type species for the genus Zonalapollenites. Also, according to article 37 (Lanjouw and others, 1966), the indication of a type species for a new genus was not a requirement for validation until January $1,1958$.

Potonié (1958, p. 48) considered Tsugaepollenites Potonié and Venitz, 1934 a valid name. He designated Tsugaepollenites (al. Sporonites) igniculus (Potonié, 1931) Potonié and Venitz, 1934 as the "Genotypus" for Tsugaepollenites. He described the genotypus but did not describe the genus Tsugaepollenites.

Tsugaepollenites was described by Jansonius (1962, p. 51) and the name was then validated; however, it was a junior synonym of the earlier validated name $Z$ onalapollenites.

Pocock (1968, p. 639-640) recognized Zonalapollenites as a validly published name and considered Tsugaepollenites its junior synonym. He formally assigned Zonalapollenites igniculus as its type species.

\section{Zonalapollenites sp. \\ Plate 5, figure 1; table 1, No. 88 BISACCATES \\ Genus ALISPORITES Daugherty, 1941}

Alisporites Daugherty, 1941, p. 98.

Alisporites Daugherty, 1941. In Potonié and Kremp, 1956, p. 176-177.
Alisporites Daugherty, 1941. In Potonié, 1958, p. 60. Alisporites Daugherty, 1941. In Potonié, 1966, p. 119.

Type species.-Alisporites opii Daugherty, 1941, p. 98, pl. 34, fig. 2; Arizona; Chinle Formation; Late Triassic.

\section{Alisporites grandis (Cookson, 1953b) Dettmann, 1963}

Plate 5, figures 2, 3; table 1, No. 46

Disaccites grandis Cookson, 1953b, p. 471-472.

Pityosporites grandis (Cookson) Balme, 1957, p. 36, pl. 10, figs. 110, 111; Western Australia; Early Cretaceous.

Alisporites rotundus Rouse, 1959, p. 316, pl. 1, figs. 15, 16; British Columbia, Canada; Late Jurassic(?).

Alisporites rotundus Rouse. In Pocock, 1962, p. 61-62, pl. 9, figs. 140, 141 western Canada; Early Cretaceous.

Alisporites grandis (Cookson) Dettmann, 1963, p. 102, pl. XXV, figs. 1-4; southeastern Australia; late Mesozoic.

Alisporites grandis (Cookson) Dettmann, 1963. In Srivastava, 1966, p. 524, pl. VI, figs. 5, 7, 10; Alberta, Canada; Maestrichtian, Late Cretaceous.

Alisporites grandis (Cookson) Dettmann. In Norris, 1967, p. 101, pl. 15, fig. 1; central Alberta, Canada; Iower part of Colorado Group; Albian-?Cenomanian.

Holotype.-In Cookson, 1953b, p. 471-472, pl. 2, fig. 41; Comaum, South Australia; Mesozoic.

\section{Alisporites thomasii (Couper, 1958) Nilsson, 1958}

Plate 5, figures 4, 5; table 1, No. 47

Pteruchipollenites thomasii Couper, 1958 (March), p. 150 151.

Alisporites thomasii (Couper) Nilsson, 1958 (November), p. 83-84, pl. 8, fig. 1; Höganäs, southern Sweden: Lias.

Alisporites bilateralis Rouse, 1959, p. 316, pl. 1, figs. 10, 11; southeastern British Columbia, Canada; Kootenay Formation; Early Cretaceous.

Alisporites thomasii (Couper) Pocock, 1962, p. 62-63, pl. 9, figs. 142, 143; western Canada; Vanguard Formation; Late Jurassic; and quartz sand member of Mannville Group; Early Cretaceous.

Alisporites thomasii (Couper) Pocock, 1962. In Singh, 1964, p. 109, pl. 14, figs. 11, 12; east-central Alberta, Canada; Mannville Group; Early Cretaceous.

Alisporites bilateralis Rouse, 1959. In Hedlund, 1966, p. 23, pl. 7, fig. 3; Bryan County, Okla.; Woodbine Formation; Cenomanian.

Alisporites bilateralis Rouse. In Norris, 1967, p. 101, pl. 14, figs. 18, 19; central Alberta, Canada; lower part, Colorado Group; Albian-?Cenomanian.

Holotype.-In Couper, 1958, p. 150, pl. 26, fig. 10 ; northeastern Scotland; Middle Jurassic.

\section{Genus ABIETINEAEPOLLENITES Potonié, 1951 ex Delcourt and Sprumont, 1955}

Abietineae-pollenites Potonié, 1951, p. 144-145. (Not valid, genus not described.)

Abietineaepollenites Potonié, 1951 ex Delcourt and Sprumont, 1955 , p. 51.

Type species.- (designated by Delcourt and Sprumont, 1955, p. 51) Abietineaepollenites (Piceaepollenites) microalatus (Potonié. 1931c) Delcourt 
and Sprumont, 1955. Holotype in Potonié, 1931c, p. 5, fig. 34; Lausitz, Germany; Miocene.

Abietineaepollenites varius Norton in Norton and Hall, 1969

Plate 5, figure 6; table 1, No. 70

Abietineaepollenites varius Norton in Norton and Hall, 1969, p. 29.

Holotype.-In Norton and Hall, 1969, p. 29, pl. 4, fig. 5; Montana; Hell Creek Formation; Late Cretaceous.

\section{Genus CEDRIPITES Wodehouse, 1933}

Cedripites Wodehouse, 1933, p. 490.

Cedripites Wodehouse, 1933. In Singh, 1964, p. 111.

Cedripites Wodehouse, 1933. In Pocock, 1962, p. 63.

Type species.-Cedripites eocenicus Wodehouse, 1933, p. 490-491, fig. 13; Colorado or Utah; Green River Formation; middle Eocene.

Cedripites parvus Norton in Norton and Hall, 1969

Plate 5, figure 7; table 1, No. 48

Cedripites parvus Norton in Norton and Hall, 1969, p. 29.

Holotype.-In Norton and Hall, 1969, p. 29 ; pl.

4, fig. 7; Montana; Tullock Member of Fort Union Formation; Paleocene.

Cedripites cretaceus Pocock, 1962

Plate 5, figure 8; table 1, No. 68

Cedripites cretaceus Pocock, 1962, p. 63.

Cedripites cretaceus Pocock, 1962. In Singh, 1964, p. 111, pl. 15, figs. 3-5; east-central Alberta, Canada; Mannville Group; Early Cretaceous.

Cedripites cretaceus Pocock. In Norris, 1967, p. 101, pl. 14, figs. 20, 21 and pl. 15, fig. 5; central Alberta, Canada; lower part of Colorado Group; Albian-?Cenomanian.

Holotype.-In Pocock, 1962, p. 63, pl. 9, fig. 145; western Canada; Quartz Sand Memiber, Mannville Group; Barremian.

Genus PITYOSPORITES Seward, 1914 emend. Manum, 1960

[in part] Pityosporites Seward, 1914, p. 23.

Pityosporites Seward, 1914 emend. Potonié and Klaus, 1954, p. 534-536.

Pinuspollenites Raatz, 1937 ex Potonié, 1958, p. 62.

Pityosporites Seward, 1914 emend. Manum, 1960, p. 14.

Pityosporites Seward, 1914 emend. Manum, 1960. In Singh, 1964, p. 121-122.

Type species.-Pityosporites antarcticus Seward, 1914. In Manum, 1960 , p. 14, figs. 1-4 (type specimen).

\section{Pityosporites constrictus Singh, 1964}

Pityosporites constrictus Singh, 1964, p. 122-123, pl. 16, figs. 8, 9.

Pityosporites constrictus Singh, 1964. In Srivastava, 1966, p. 524, pl. VI, fig. 2; Scollard, Alberta, Canada; Edmonton Formation; Maestrichtian, Late Cretaceous.

Holotype.-In Singh, 1964, p. 122-123, pl. 16, fig. 8; Fort Augustus No. 1 well, Aberta, Canada; El- lerslie Member of McMurray Formation, Mannville Group; Early Cretaceous.

Pityosporites cf. P. constrictus

Plate 5, figure 9; table 1, No. 49

Remarks.-Except for their slightly smaller size (total breadth of grains $49 \mu-70 \mu$ ) these grains appear very similar to those of $P$. constrictus that were described and illustrated by Singh.

Pityosporites alatipollenites (Rouse, 1959) Singh, 1964

Plate 6, figure 1; table 1, No. 81

Pinus alatipollenites Rouse, 1959, p. 314, pl. 1, fig. 7; southeastern British Columbia, Canada; Kootenay Formation; Late Jurassic (?).

Pityosporites alatipollenites (Rouse) Singh, 1964, p. 123, pl. 16, fig. 10; east-central Alberta, Canada; Mannville Group; Early Cretaceous.

Holotype.-In Radforth and Rouse, 1954, p. 195, pl. I, fig. 15; Entrance, Alberta, Canada; Brazeau Formation; Late Cretaceous.

Pityosporites elongatus Norton in Norton and Hall, 1969 n. comb.

Pinuspollenites elongatus Norton in Norton and Hall, 1969, p. 27.

Holotype.-In Norton and Hall, 1969, p. 27, pl. 4, fig. 1; Garfield County, Mont.; Tullock Member of Fort Union Formation; Paleocene.

Pityosporites elongatus (Norton) Tschudy var. elongatus

Plate 6, figures 2-4; table 1, No. 50

Holotype.-Same as for Pityosporites elongatus (see above).

Pityosporites elongatus var. grandis n. var.

Plate 6, figures 5, 6; table 1, No. 51

Holotype.-USGS paleobotany locality D3726-E, slide (5) at $116.0 \times 4.9$; plate 6 , figure 6 ; center NE $1 / 4$ sec. 31, T. 23 N., R. 17 E.; Fergus County, Mont.; Judith River Formation (lower marine part); late Campanian.

Paratype:-USGS paleobotany locality D3726-E, slide (6) at $96.9 \times 13.2$; plate 6 , figure 5 ; same locality data as for holotype.

Description (based on 28 specimens).-Bisaccate pollen grains. In polar view central body circular to slightly oval-in some specimens body breadth greater than length, in others length greater than breadth; sacci distinctly to slightly smaller than body, slightly more than semicircular to almost circular in outline, narrowing toward roots. Dorsal attachment of sacci at equator or slightly beyond; sacci distally pendant, clearly set off from body, a distinct reentrant angle present where proximal roots of sacci join the central body. Marginal ridge not present. Distal tenuitas $17 \mu-21 \mu$ wide. Wall of 
proximal cap $1 \mu-2 \mu$ thick; columnar layer visible at $\times 1,000$ magnification, tectate; surface of tectum smooth; infrareticulum very fine. Sacci irregularly reticulate, lumina $0.5 \mu-3 \mu$ in diameter.

Observations on many specimens indicate the body of this species probably was originally nearly spherical.

Size range (in microns) (terminology based on Pocock (1962, p. 59-60) .-

Length of bladders _-_._-_._- $42-71$

Length of central body -

Breadth of bladders _-_._- 31-59

Total breadth of grain _._._.

Height of central body _._.

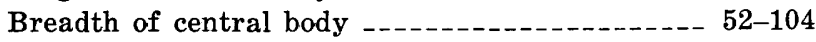

Comparison with similar species.-P. elongatus var. grandis is larger than Pityosporites alatipollenites (Rouse) Singh (1964, p. 123), and the ornamentation of the sacci of $P$. elongatus var. grandis is very distinct from that of the body, whereas Rouse (1959, p. 314) described the ornamentation of $P$. alatipollenites as more or less uniform on body and bladders. Except for its larger size, $P$. elongatus var. grandis resembles Pityosporites elongatus Norton n. comb.

\section{Genus PODOCARPIDITES Cookson ex Couper, 1953 emend.} Potonié, 1958

Disaccites (Podocarpidites) Cookson, 1947, p. 131.

[in part] Podocarpidites Cookson, 1947 ex Couper, 1953, p. 35.

Podocarpidites Cookson, 1947 ex Couper, 1953 emend. Potonié, 1958, p. 68.

Type species.-(designated by Couper, 1953, p. 35) Podocarpidites ellipticus Cookson, 1947; lectotype (designated by Potonié, 1958, p. 68) in Cookson, 1947, p. 131, pl. XIII, fig. 6; Waterfall Gorge, Kerguelen Archipelago; Tertiary.

Podocarpidites multesimus (Bolkhovitina, 1956) Pocock, 1962

Plate 7, figures 1,2 ; table 1, No. 89

Podocarpus multesimus Bolkhovitina, 1956, p. 127.

Podocarpidites biformis Rouse, 1957, p. 367, pl. II, fig. 13; south-central Alberta, Canada; Oldman Formation; Late Cretaceous.

Podocarpidites multesimus (Bolkhovitina, 1956) Pocock, 1962, p. 67; western Canada; Mannville Formation; Early Cretaceous.

Podocarpidites multesimus (Bolkhovitina) Pocock, 1962. In Singh, 1964, p. 116, pl. 15, figs. 12, 13; east-central Alberta, Canada; Mannville Group; Early Cretaceous.

Holotype.-In Bolkhovitina, 1956, p. 127, pl. XXIV, fig. 235; Vilyui Basin, U.S.S.R.; Early Jurassic.

Remarks.-The specimens from the Judith River Formation samples which are here identified as $P$. multesimus also resemble Podocarpidites maximus (Stanley, 1965) Norton (in Norton and Hall, 1969, p. 31). $P$. maximus resembles $P$. multesimus and may be synonymous with it.

\section{Podocarpidites ornatus Pocock, 1962}

Podocarpidites ornatus Pocock, 1962, p. 67-68.

Holotype.-In Pocock, 1962, p. 67-68, pl. 11, fig. 164 ; western Canada; Quartz Sand Member, Mannville Group; Barremian.

Podocarpidites cf. P. ornatus

Plate 7, figure 3; table 1, No. 52

Genus PRISTINUSPOLLENITES n. gen.

Type species.-Pristinuspollenites (Alisporites) microsaccus (Couper) (Pocock, 1962) n. comb. (See p. 17.)

Description.-Bisaccate pollen grains. In polar view outline of grain ellipsoidal to circular. Length of body equal to, slightly greater than, or slightly less than its breadth. Sacci distally attached (entirely on distal side of equator), clearly set off from body, very small in comparison to body, in fossilized state variously inclined-either leaning toward or away from the tenuitas; sacci on some specimens and in some species wrinkled or slightly ruffled. Tuberclelike thickenings never present at base of sacci (as in Dacrydiumites Cookson, 1953a). Distal sulcus clearly defined in some specimens. Body variously ornamented, sacci finely or indistinctly reticulate but never coarsely reticulate.

Remarks.-Pristinuspollenites was erected to accommodate a group of distinctive bisaccate pollen species which have greatly reduced distally attached sacci and which do not have thickenings at the base of the sacci (as in Dacrydiumites).

Pristinuspollenites (Pteruchipollenites) microsaccus Couper, $1958 \mathrm{n}$. comb. was designated as the type species for the genus because it was an adequately described and illustrated species and has the characteristics that represent Pristinuspollenites.

New combinations and new names:

Pristinuspollenites (Bacubivesiculites) inchoatus (Pierce, 1961) n. comb. (Holotype in Pierce, 1961, p. 34, pl. II, fig. 35; Minnesota; early Late Cretaceous. Also illustrated in this report: pl. 7, fig. 7.)

Pristinuspollenites (Clavabivesiculites inchoatus Pierce, 1961) crassus n. name. (Holotype in Pierce, 1961, p. 34-35, pl. II, fig. 36 ; Minnesota ; early Late Cretaceous. Also illustrated in this report: pl. 7, figs. 8, 9.) The new species name crassus was here introduced because Pristinuspollenites (Clavabivesiculites) inchoatus (Pierce, 1961) n. comb. would have been a 
later homonym of Pristinuspollenites (Bacubivesiculites) inchoatus. (See above.)

Pristinuspollenites (Clavabivesiculites) pannosus (Pierce, 1961) n. comb. (Holotype in Pierce, 1961, p. 35, pl. II, fig. 37; Minnesota; early Late Cretaceous. Also illustrated in this report: pl. 7, fig. 10.)

Pristinuspollenites (Granabivesiculites inchoatus Pierce, 1961) sulcatus n. name. (Holotype in Pierce, 1961, p. 35, pl. II, fig. 38; Minnesota; early Late Cretaceous. Also illustrated in this report: pl. 7, fig. 11.) The new species name sulcatus was here introduced because Pristinuspollenites (Granabivesiculites) inchoatus (Pierce, 1961) n. comb. would have been a later homonym of Pristinuspollenites (Bacubivesiculites) inchoatus (see above).

Pristinuspollenites (Phyllocladidites) microreticulatus (Brenner, 1963) n. comb. (Holotype in Brenner, 1963, p. 79-80, pl. 30, fig. 3a-b; Maryland; Early Cretaceous.)

Pristinuspollenites (Parvisaccites) granisaccus (Hedlund, 1966) n. comb. (Holotype in Hedlund, 1966, p. 22-23, pl. 6, fig. 6a ; Oklahoma; Cenomanian.) This species appears to be very similar to, and is probably synonymous with, Pristinuspollenites sulcatus. (See above.)

Remarks.-Norris (1967, p. 103) transferred Granabivesiculites inchoatus Pierce to Phyllocladidites Cookson ex Couper. This is not an acceptable transfer because Granabivesiculites inchoatus Pierce (holotype illustration, this report, pl. 7, fig. 11) does not have proximal tubercles and thus does not fit into Dacrydiumites Cookson, 1953 (synonym Phyllocladidites). In his description of the species, Norris did not mention if his specimens from central Alberta have proximal tubercles. There is no indication of tubercles at the base of the sacci in his specimens illustrated in his plate 15 , figures 8,9 . Those specimens closely resemble and may be assignable to Pristinuspollenites microsaccus.

Pocock (1962, p. 61) had transferred the species Pteruchipollenites microsaccus Couper to the genus Alisporites, a genus to which that small winged taxon does not conform.

Comparison.-Pristinuspollenites n. gen. is distinguishable from Dacrydiumites by its lack of thickenings ("proximal tubercles" of Cookson, 1947, p. 133) at the base of the sacci.

Pristinuspollenites, in common with Parcisporites Leschik (1956, p. 55), has strongly reduced sacci but differs in that its sacci are distinctly delineated from the body whereas in Parcisporites the zone or line of attachment of the sacci is irregular or indefi- nite. The sacci of Parcisporites are apparently attached much closer to the equator than are those of Pristinuspollenites.

The sacci of Pristinuspollenites are not veillike as are those of Indusiisporites Leschik $(1956$, p. 55).

Pristinuspollenites does not have radially arranged thickenings on the sacci as does Parvisaccites Couper (1958, p. 154).

Distribution.-In addition to the species localities mentioned above (under new combinations and new names), forms assignable to this genus have been reported from several other parts of the Northern Hemisphere. Specimens that seem to conform to Pristinuspollenites were reported from the Cretaceous of the U.S.S.R by Bolkhovitina (1953, p. 74, pl. XI, figs. 5, 6) and by Chlonova (1960, p. 60-61, pl. IX, figs. 6, 7). Chlonova (1961, p. 67, pl. XI, fig. 70) assigned a specimen from the Cenomanian-Turonian of the Chulymn-Enisei depression of the U.S.S.R. to the species Pteruchipollenites microsaccus Couper. Dacrydium? transiens Sato (1961, p. 89-90, pl. I, fig. 23) from the Upper Cretaceous of Japan appears to be assignable to the genus Pristinuspollenites.

Robert Tschudy (oral commun., March 1971) reported several forms assignable to Pristinuspollenites from Upper Cretaceous rocks from the Appalachian Mountains region of the United States.

Pristinuspollenites microsaccus (Couper, 1958) n. comb.

Plate 7, figures 4-6; table 1, No. 82

Pteruchipollenites microsaccus Couper, 1958, p. 151, pl. 26, figs. 13, 14.

Alisporites (Pteruchipollenites) microsaccus (Couper) Pocock, 1962 , p. 61.

Alisporites microsaccus (Couper, 1958) Pocock, 1962. In Burger, 1966 , p. 259 , pl. 35, figs. 1a, b; eastern Netherlands; Lias, Jurassic.

Holotype.-In Couper, 1958, p. 151, pl. 26, fig. 13; Cambridge Observatory Borehole, southeastern England; Upper Estuarine Series; Middle Jurassic.

Description (based on Couper's description and illustrations and on 11 specimens from Judith River Formation samples-all specimens in polar and oblique polar views).-Bisaccate pollen grains. In polar view, outline of grain ellipsoidal to circular. Length of body equal to, slightly greater than, or slightly less than its breadth. Sacci distally attached, clearly set off from body, much smaller than body; sacci arc-shaped, in some specimens one or both sacci wrinkled or distorted; maximum length of sacci at their base, length of sacci greater than their breadth; sacci variously inclined-either leaning toward or away from the tenuitas, appearing flattened or slightly inflated. Proximal tubercles not present at base of sacci. Distal sulcus not clearly 
defined, in most specimens not distinguishable. Proximal cap $1 \mu-1.5 \mu$ thick, sculpture scabrate. Body wall slightly finer textured and appearing thinner in area between bladders than on proximal cap. Sculpture of sacci finely and indistinctly reticulate. Sacci in reclined position covering as much as half the distal surface of grain; in true polar position of grains sacci not contributing to outline of grain.

Size range (in microns).-

$\begin{array}{llcc}\text { Length of central body - } & \text { Couper } & \text { Tschudy } & \begin{array}{c}\text { Copecimens } \\ \text { (Couper and } \\ \text { Tsehudy) }\end{array} \\ \text { Breadth of central body- } & 30-58 & 37-56 & 37-78 \\ \text { Length of sacci - }-1--- & 53-75 & 25-46 & 30-58 \\ \text { Breadth of sacci --_-- } & 18-30 & 7-13 & 25-75 \\ \text { Total breadth of grain - } & 35-63 & 30-46 & 30-63\end{array}$

Remarks.-My specimens from the Judith River Formation of Montana, except that many of them are smaller, closely resemble those of $P$. microsaccus as it was described and illustrated by Couper.

Comparison.-Pristinuspollenites sulcatus n. name (see p. 17) resembles Pristinuspollenites microsaccus n. comb. but is distinguishable because of its broad and clearly defined sulcus. P. sulcatus also tends to have a thicker proximal cap than $P$. microsaccus and its sacci tend to be narrower at their roots.

\section{Genus RUGUBIVESICULITES Pierce, 1961}

Rugubivesiculites Pierce, 1961, p. 39.

Type species.-Rugubivesiculites convolutus Pierce, 1961, p. 39-40, pl. II, fig. 57; Minnesota; early Late Cretaceous.

\section{Rugubivesiculites sp.}

Plate 7, figures 12, 13; table 1, No. 15

Remarks.-These specimens resemble photographs of Pinus ruginosa Stanley (1965, p. 277, pl. 39, figs. 1-7) but apparently are different because Stanley described $P$. ruginosa as having a finely to moderately reticulate cap and my specimens from the Judith River Formation from Montana have a finely rugulate cap.

My specimens also resemble Rugubivesiculites minimus Burger (1966, p. 257, pl. 33, fig. 3), except that their proximal cap seems to be more finely ornamented.

Genus VITREISPORITES Leschik, 1955 sensu Potonié, 1958

Vitreisporites Leschik, 1955, p. 53.

Vitreisporites Leschik, 1955. In Potonié, 1958 (January), p. 56.

Caytonipollenites Couper, 1958 (March), p. 149.

Caytoniales-Pollenites Pautsch, 1958 (July), p. 323.

Vitreisporites Leschik. In Nilsson, 1958 (November), p. 7778.

Vitreisporites Leschik, 1955 emend. Jansonius, 1962 (April), p. 55.
Vitreisporites (Leschik) Jansonius. In Pocock, 1962 (October), p. 58 .

Vitreisporites (Leschik) Jansonius emend. De Jersey, 1964, p. 9.

Vitreisporites Leschik, 1955, emend. Jansonius, 1962. In Singh, 1964, p. 102.

Type species.-Vitreisporites signatus Leschik, 1955, p. 53-54; pl. 8, fig. 10; Neuewelt near Basel, Switzerland; Keuper, middle Late Triassic.

Remarks.-Vitreisporites was described by Leschik $(1955$, p. 53) as having a weak Y-mark on the proximal pole. Potonié (1958, p. 56) and Nilsson (1958, p. 77-78) in their descriptions of Vitreisporites did not omit the $\mathrm{Y}$-mark distinction but included within the genus those forms not having, as well as those having, a Y-mark. Jansonius (1962, p. 55) in his emendation of Vitreisporites omitted any designation of a Y-mark because he was of the opinion that a Y-mark had not been demonstrated convincingly. Pocock (1962, p. 58) and Singh (1964, p. 102) also omitted recognition of the Y-mark from their descriptions of Vitreisporites. De Jersey (1964, p. 9) reemended Vitreisporites (Leschik) Jansonius, merely expanding the genus to allow for the inclusion of grains with little, if any, ornamentation on the bladders. I accept Vitreisporites (Leschik) sensu Potonié in preference to Vitreisporites (Leschik) Jansonius because I do not believe the Y-mark designation should be excluded from the genus description when it was an important characteristic of the genus and of its type species as they were originally described by Leschik.

\section{Vitreisporites pallidus (Reissinger) Nilsson, 1958}

Plate 8, figures 1, 2; table 1, No. 53

Pityosporites pallidus Reissinger, 1939, p. 14.

Pityopollenites pallidus (Reissinger) Reissinger, 1950, p. 109, pl. XV, figs. 1-5. (Pityopollenites used as a new genus but not described.)

Pityosporites pallidus Reissinger. In Balme, 1957, p. 36-37, pl. 10, figs. 112, 113; Western Australia; Mesozoic.

Caytonipollenites pallidus (Reissinger) Couper, 1958, p. 150, pl. 26, figs. 7, 8; Yorkshire, England; Middle Jurassic. Isle of Wight, England; Aptian.

Vitreisporites pallidus (Reissinger) Nilsson, 1958, p. 78-79, pl. 7, figs. 12-14; Sweden; Lias.

Caytonipollenites pallidus (Reissinger) Coupèr. In Lantz, 1958, p. 926, figs. 46, 47; Dorset, Great Britain; Jurassic.

Vitreisporites pallidus (Reissinger) Nilsson. In Pocock, 1962, p. 58-59, pl. 9, figs. 134, 135; western Canada; Deville Member and quartz sand member of Mannville Group; Early Cretaceous.

Vitreisporites pallidus (Reissinger) Nilsson, 1958. In Balme, 1963, p. 24-25, pl. 6, fig. 7; western Australia; Kockatea Shale; Early Triassic.

Vitreisporites pallidus (Reissinger) Brenner, 1963, p. 74, pl. 25, figs. 1, 2; Maryland; Patapsco and Patuxent Formations of Potomac Group; Early Cretaceous. 
Vitreisporites pallidus (Reissinger) Nilsson, 1958. In Singh, 1964, p. 102-103, pl. 14, fig. 1; east-central Alberta, Canada; Grand Rapids Formation of Mannville Group; Albian.

Caytonipollenites pallidus (Reissinger) Couper. In Leopold and Pakiser, 1964, p. 82, 88, pl. 6, figs. 33, 34; western Alabama; Eutaw Formation; Late Cretaceous.

Vitreisporites pallidus (Reissinger) Nilsson, 1958. In Playford and Dettmann, 1965, p. 156, pl. 17, fig. 58; South Australia; Rhaetic-Liassic.

Vitreisporites pallidus (Reissinger) Brenner. In Habib, 1969 pl. 2, fig. 11; deep-sea core, northeast of Cat Island, the Bahamas, West Indies; middle Cretaceous.

Lectotype.-(here assigned) In Reissinger (1950, pl. XV, fig. 5; Teufelsgraben near Altdorf, east from Nürnberg, Germany; Lias; Early Jurassic.

Remarks.-Grains resembling Vitreisporites pallidus have been reported from Cretaceous deposits of Russia by Bolkhovitina (1953, p. 72-73, pl. XI, fig. 1) and by Chlonova (1961, p. 65, pl. XI, figs. 66, 67).

Description (based on 30 specimens).-Bisaccate pollen grains, shape oval in polar view; total breadth of grain $25 \mu-38 \mu$, length of bladders $11 \mu-21 \mu$, breadth of bladders $7.5 \mu-16 \mu$, length of central body $14 \mu-21 \mu$, breadth of central body $7 \mu-16 \mu$; sulcus not discernible in specimens examined; exine of bladders approximately $0.5 \mu$ thick, sculpture finely and irregularly reticulate; exine of body thinner than that of bladders, sculpture smooth to granulate.

Similar species.-Vitreisporites pallidus resembles Vitreisporites signatus Leschik but differs in that it does not have a Y-mark on the proximal pole.

\section{MISCELLANY}

Genus TAXOdiaceaePOLlenites Kremp, 1949 ex Potonié, 1958

Taxodiaceaepollenites Kremp, 1949 ex Potonié, 1958, p. 78-79. Type species.—Taxodiaceaepollenites (Pollenites) hiatus (Potonié) Kremp, 1949 ex Potonié, 1958.

Taxodiaceaepollenites hiatus (Potonié) Kremp, 1949 ex Potonié, 1958 Plate 8 , figures 3,4 ; table 1, No. 18

Pollenites hiatus Potonié, 1931c, p. 5.

Taxodium hiatipites Wodehouse, 1933, p. 493-494, fig. 19 (not fig. 17 as stated). (Wodehouse compared this species with species of Taxodium, Juniperus, Libocedrus, Thuja, and Zamia).

Taxodieae-Poll. hiatus Potonié. In Thiergart, 1940, p. 30.

Taxodiaceae-Poll. hiatus Potonié. In Kremp, 1949, p. 59.

Taxodiaceae-Poll, hiatus Potonié. In Kremp, 1949, p. 91.

Taxodoidites hiatus Potonié. In Potonié, Thomson, and Thiergart, 1950 , p. 49. (In this report also spelled Taxodioidites.)

Taxodioipoll. hiatus Potonié. In Potonié, 1951, p. 140, 149.

Inaperturopollenites hiatus (Potonié) Thomson and Pflug, 1953 , p. 65.

Taxodiaceaepollenites hiatus (Potonié, 1931) Kremp, 1949. In Potonié, 1958, p. 79.
Taxodieaepollenites hiatus (Potonié, 1931). In Kremp and Gerhard, 1961, p. 265.

Thuja? hiatus (Potonié) Stanley, 1965, p. 273-274.

Holotype.-In Potonié, 1931c, p. 5, fig. 27 ; Ville bei Köln, Beisselsgrube; (Oligocene) Miocene.

Description.-Pollen grains, probably originally spherical but characteristically split from one-half to nearly total diameter of grain; the split varying from narrow $V$-shaped to broadly gaping. Exine approximately $0.5 \mu$ thick, wall layers not distinguishable, surface smooth to scabrate.

Remarks.-The species first described as Pollenites hiatus Potonié (1931c, p. 5) has since been included in combination with a succession of valid and invalid names.

Thiergart (1940, p. 30) used the combination Taxodieae-Poll. hiatus but obviously did not intend that as a formal binomial name, because in his illustrations he referred to the grains as "Taxodium," "cf. Taxodium," and "Taxodieae" rather than as Taxodieae-Poll. hiatus. Furthermore, Taxodieae-Poll. Thiergart, 1940, could not be considered a valid name under the provision of Article 42 of the "International Code of Botanical Nomenclature" (Lanjouw, chm., and others, 1966) because the taxon hiatus was not a new species and because Taxodieae-Poll. Thiergart was not monotypic-Thiergart in the same report also described the new form "Poll. hiatus $\mathrm{R}$. Pot. paleocaenicus n.f."

Kremp (1949, p. 59) used the combination Taxodiaceae-Poll. hiatus but it is not clear whether he intended Taxodiaceae-Pollenites as a generic name because he (p. 91) merely placed Pollenites hiatus in the family Taxodiaceae. At any rate, TaxodiaceaePoll. Kremp, 1949, was not valid. The species hiatus was not new and consequently Taxodiaceae-Pollenites could not have been valid under the provision of Article 42 (Lanjouw, chm., and others, 1966).

Potonié, Thomson, and Thiergart (1950, p. 49) used the combination Taxodoidites hiatus (probably a misprint, as this was under the heading Taxodioidites). They did not describe Taxodoidites (or Taxioidites) or designate it as a new genus.

Potonié (1951, p. 140, 149) used the combination Taxodioipoll. hiatus but did not describe it.

The first valid new combination was that in Thomson and Pflug (1953, p. 64, 65)-where the new genus Inaperturopollenites Pfiug and Thomson was described and the species hiatus Potonié was formally transferred to it.

Taxodiaceaepollenites became a valid name when Potonié (1958, p. 78-79) used it as a generic name, described it, and designated Taxodiaceaepollenites 
(al. Pollenites) hiatus (Potonié, 1931) Kremp, 1949 as its type species (Genotypus).

Kremp and Gerhard (1961, p. 265) considered Taxodiaceae-pollenites hiatus (Potonié, 1931) Kremp, 1949, a synonym of Taxodieae-pollenites hiatus (Potonié, 1931) Theirgart, 1940. It is true, "Taxodieae-Poll." was the first name other than Pollenites to be used in combination with the species hiatus but it was not a valid name.

Stanley (1965, p. 273-274) transferred the species hiatus to Thuja? This combination is not acceptable because "Thuja?" is not a proper generic name.

In the present report, Taxodiaceaepollenites is considered to be a form genus because I believe that it cannot be assigned with certainty to the family Taxodiaceae. Taxodiaceaepollenites as defined by Potonié (1958, p. 79), is clearly distinguishable from Inaperturopollenites Pflug and Thomson as emended by Potonié (1958, p. 77-78).

\section{Genus SEQUOIAPOLLENITES Thiergart, 1937}

Sequoia-pollenites Thiergart, 1937, p. 301-302.

Sequoiapollenites Thiergart, 1937. In Potonié, 1958, p. 79-80. Sequoiapollenites Thiergart. In Manum, 1962, p. 43-44.

Type species. - Sequoiapollenites polyformosus Thiergart, 1937, p. 301-302, pl. 23, fig. 6 (lectotype, selected by Potonié, 1958, p. 79) ; Senftenberg, Germany; Miocene.

\section{Sequoiapollenites spp.}

Plate 8, figures 5, 6; table 1 , No. 90

Genus CLASSOPOLLIS Pflug, 1953 emend. Pocock and Jansonius, 1961

Classopollis Pflug, 1953, p. 91.

Classopollis Pflug, 1953 emend. Pocock and Jansonius, 1961, p. 443 .

Classopollis (Pflug, 1953) Pocock and Jansonius, 1961. In Potonié, 1966, p. 130-132.

Type species. - Classopollis classoides Pflug emend. Pocock and Jansonius, 1961, p. 443-444; holotype in Pflug, 1953, p. 91, pl. 16, figs. 29-31 (three levels) ; Siegelsum, Germany; Lias, Early Jurassic.

\section{Classopollis spp.}

Plate 8 , figures 7,8 ; table 1 , No. 54

Genus EQUISETOSPORITES Daugherty, 1941 emend. Singh. 1964

Equisetosporites Daugherty, 1941, p. 63.

Equisetosporites Daugherty, 1941 emend. Singh. 1964, p. 129. Equisetosporites Daugherty emend. Singh, 1964. In Srivastava, 1968 b, p. 216.

Type species.-Equisetosporites chinleana Daugherty, 1941, p. 63, pl. 24, fig. 4; Arizona; Late Triassic.

\section{MONOSULCATES}

Genus ARECIPITES Wodehouse, 1933

Arecipites Wodehouse, 1933, p. 497.

Arecipites Wodehouse, 1933. In Potonié, 1958, p. 97.

Type species.-(selected by Potonié, 1958, p. 97) Arecipites punctatus Wodehouse, 1933, p. 497, fig. 22; Colorado or Utah; Green River Formation; Eocene.

\section{Arecipites sp.}

Plate 8, figure 11; table 1, No. 21

Genus LILIACIDITES Couper, 1953

Liliacidites Couper, 1953, p. 56.

Retimonocolpites Pierce, 1961, p. 47.

Type species._Liliacidites kaitangataensis Couper, 1953, p. 56, pl. 7, fig. 97 (holotype) ; Kaitangata Coalfield, New Zealand; sub-Wangaloan; Late Cretaceous.

Liliacidites variegatus Couper, 1953

Plate 8 , figure 12 ; table 1 , No. 55

Liliacidites variegatus Couper, 1953, p. 56.

Liliacidites variegatus Couper, 1953. In Rouse, 1957, p. 368 , pl. II, figs. 29, 30; south-central Alberta, Canada; Oldman Formation; Santonian.

Liliacidites variegatus Couper, 1953. In Srivastava, 1966, p. 525, pl. IV, figs. 15, 16, Scollard, Alberta, Canada; Edmonton Formation; Maestrichtian.

Liliacidites variegatus Couper, 1953. In Elsik, 1968a, p. 312, pl. XV, fig. 1; Milam County, Tex.; Rockdale Formation; Paleocene.

Liliacidites variegatus Couper, 1953. In Srivastava, 1969b, p. 977, pl. I, fig. 10; Alberta, Canada; Edmonton Formation; Maestrichtian.

Holotype.-In Couper, 1953, p. 56, pl. 7, fig. 99; Mataura Valley, Southland, New Zealand; Landonian, early to middle Oligocene. (Holotype also illustrated in Couper, 1960, pl. 9, fig. 9.)

Liliacidites morrinensis Srivastava, 1969b

Liliacidites morrinensis Srivastava, 1969b, p. 977.

Holotype.-In Srivastava, 1969b, p. 977, pl. I, fig. 9 ; near Morrin, Alberta, Canada; Edmonton Formation; Maestrichtian.

\section{Liliacidites cf. L. morrinensis}

Plate 8 , figure 13 ; table 1 , No. 95

Liliacidites complexus (Stanley, 1965) Leffingwell, 1971

Plate 8, figures 14, 15; table 1, No. 20

Schizosporis complexus Stanley, 1965, p. 267-268, pl. 36, figs. 7-17.

Schizosporis complexus Stanley. In Norton and Hall, 1969, p. 58, pl. 3, fig. 9; Montana; Fox Hills Sandstone; Maestrichtian.

Liliacidites complexus (Stanley, 1965) Leffingwell, 1971, p. 41, pl. 7, fig. 3; Wyoming; Lance Formation; Late Cretaceous.

Holotype.-In Stanley, 1965, p. 267-268, pl. 36, 
figs. 7-9 (three levels); Crow Butte, Harding County, S. Dak.; Hell Creek Formation; Maestrichtian.

Description (based on 30 specimens from USGS paleobotany locality samples from the Judith River Formation of Montana).-Monosulcate, bilateral pollen grains; shape oval to almost circular; size $22 \mu-33.5 \mu \times 27.5 \mu-42 \mu$. Aperture: Sulcus slitlike; as seen in distal view of grain sulcus extends approximately three-fourths the total length of grain; in some views of specimens the sulcus is not clearly visible; in some specimens a narrow smooth margo is present adjacent to sulcus. Pollen wall: Endexine thin; ektexine $1 \mu-1.5_{\mu}$ thick, surface sculpture reticulate; lumina of reticulum $1 \mu-3 \mu$ in diameter, lumina smaller on distal surface, very small near sulcus; muri as much as $0.5 \mu$ wide, duplibaculate.

Remarks. - The specimens described above vary considerably in size, shape, and coarseness of surface ornamentation; however, none of my specimens from the Judith River Formation were as large or as coarsely reticulate as one illustrated by Stanley (1965, pl. 36, figs. 13, 14). Some of my specimens are more finely reticulate than Stanley's illustrated specimens, but most of them are very similar to his holotype specimen (Stanley, 1965, pl. 36, figs. 7-9).

\section{Liliacidites spp.}

Plate 8, figures 16-18; table 1, No. 56

Genus OVOIDITES Potonié ex Krutzsch, 1959a emend. Potonié, 1966

Ovoidites Potonié, 1956, ex Krutzsch, 1959a, p. 249.

Ovoidites Potonié, 1951 emend. Potonié, 1966, p. 201-202.

Type species.-Ovoidites ligneolus (Pontonié) 1951 ex Krutzsch, 1959a.

Ovoidites ligneolus (Potonié, 1931b) Potonié, 1951 ex Krutzsch, 1959a

Plate 8 , figure 19 ; table 1, No. 69

Pollenites (?) ligneolus Potonié, 1931b, pl. 2, fig. V25a.

Sporites ligneolus (Potonié) Potonié and Venitz, 1934, p. 15, Ovoidites ligneolus (Potonié) Potonié, 1951, pl. XXI, fig. 185. (Not a valid name, species not new and genus not described.)

Ovoidites ligneolus, Potonié. In Thomson and Pflug, 1953, p. 113.

Ovoidites ligneolus (Potonié) Potonié, 1951 ex Krutzsch, $1959 \mathrm{a}$, p. 249. (Valid name because genus Ovoidites here described.)

Holotype.-In Potonié, 1931b, pl. 2, fig. V25a; Niederrheim-Bucht; Miocene.

\section{TRICOLPATES}

\section{Genus AESCULIIDITES Elsik, 1968b}

Aesculiidites Elsik, 1968b, p. 632.

Type species.-Aesculiidites (Tricolpites) circumstriatus (Fairchild) Elsik, 1968b. In Stover, Elsik, and Fairchild, 1966, p. 5, pl. 2, figs. 3-7 (holotype fig. 3a-c); Milam County, Tex.; Wilcox Group; early Eocene.

\section{Aesculiidites dubius (Jardiné and Magloire, 1965) n. comb.} Plate 8, figures 20, 21; table 1, No. 22

Striopollenites dubius Jardiné and Magloire, 1965, p. 215.

Holotype.-In Jardiné and Magloire, 1965, p. 215, pl. X, fig. 50; Sénégal, northwestern Africa; late Albian.

Remarks.-The genus Striopollenites Rouse (1962, p. 212), as already pointed out by Potonié (1966, p. 164), is synonymous with Striatopollis Krutzsch (1959b, p. 142-143). However, the holotype of Striopollenites dubius as shown in the illustration (Jardiné and Magloire, 1965, pl. X, fig. 50) has striations approximately parallel with the equator of the grain and so pertains to the genus Aesculiidites Elsik (1968b) which has circumstriate ornamentation, rather than to Striatopollis which has longitudinal striations.

Some of my specimens found in samples of the Judith River Formation are slightly smaller (range $16 \mu-21 \mu$ ) than Jardiné and Magloire's specimens (range 18 $\mu-25 \mu$ ) but otherwise they closely resemble their holotype specimen. Their plate $\mathrm{X}$, figures 48 and 49 , illustrate specimens assigned to Striopollenites dubius that appear to have longitudinal striations; these specimens probably are a different species and belong in the genus Striatopollis Krutzsch (1959b).

\section{Genus GREWIPOLLENITES Srivastava, 1969d}

Grewipollenites Srivastava, 1969d, p. 60-61.

Type species.-Grewipollenites canadensis Srivastava, 1969d, p. 61, pl. 2, fig. 27; Alberta, Canada; Edmonton Formation; Maestrichtian.

\section{Grewipollenites radiatus n. sp.}

Plate 8, figures 22-25; table 1, No. 94

Holotype.-USGS paleobotany locality D3726-D, slide $(2)$ at $104.7 \times 18.8$; plate 8 , figure 22 ; center NE1/4, sec. 31, T. 23 N., R. 17 E.; Fergus County, Mont.; Judith River Formation (lower marine part) late Campanian.

Paratype.-USGS paleobotany locality D3726-D, slide (2) at $86.0 \times 15.3$; plate, 8 , figure 23 ; same locality data as for holotype.

Paratype.-USGS paleobotany locality D3726-D, slide (2) at $88.1 \times 4.1$; plate 8 , figure 24 ; same locality data as for holotype.

Description (based on 28 specimens).-Tricolpate pollen grains; outline circular to rounded triangular; diameter $14 \mu-20 \mu$. Apertures: Colpi extending one-half to two-thirds the distance to poles, slitlike 
or gaping slightly, usually visible only in specimens that are oriented in polar view; pores in addition to colpi are suggested in some specimens, but definite pores have not been observed. Pollen wall: Walls less than $0.5 \mu$ thick, ornamented with ridges that diverge from several foci on surface of grain; ridges $1.5 \mu-3 \mu$ long, as much as $1 \mu$ high, less than $1 \mu$ wide at widest part, and tapered to sharp or blunt ends.

Comparison.-Specimens that I have described under the new species name Grewipollenites radiatus are smaller and apparently have slightly coarser surface ornamentation than Grewipollenites canadensis Srivastava; however, G. radiatus may later be found to merge with $G$. canadensis.

\section{Genus PULCHERIPOLLENTES Srivastava, 1969d}

Pulcheripollenites Srivastava, 1969d, p. 61.

Type species.-Pulcheripollenites narcissus Srivastava, 1969d, p. 61-62, pl. 2, figs. 28, 29; Alberta, Canada; Edmonton Formation; Maestrichtian.

Pulcheripollenites krempii Srivastava, 1969d

Plate 8, figures 26-28; table 1, No. 23

Pulcheripollenites krempii Srivastava, 1969 d, p. 62 .

Holotype.-In Srivastava, 1969d, p. 62, pl. 2, figs. 30, 31; Alberta, Canada; Edmonton Formation; Maestrichtian.

Description (based on 26 specimens in polar and oblique views and four in equatorial view).-Tricolpate pollen grains, radially symmetrical, angulaperturate, isopolar; outline in polar view nearly circular, to triangular with rounded corners; outline in equatorial view elliptical to rounded rhomboidal; equatorial diameter $27 \mu-49 \mu$, polar axis $27 \mu-42 \mu$, polar axis $27 \mu-42 \mu$. Apertures (as seen in polar view of grains) : Colpi short, simple, slitlike to gaping, reaching one-fourth to one-third the distance to poles. Pollen wall: Endexine in most specimens less than $0.5 \mu$ thick, in some specimens as much as $0.5 \mu$ thick near colpi where endexine is slightly thicker than on remainder of grain. Ektexine $0.5 \mu-$ $1.5 \mu$ thick, thickening to as much as $2 \mu$ near apertures. Endexinal and ektexinal thickening of wall begins approximately $10 \mu$ from colpi and continues to colpal slits-in this area tops of muri sheathed by a tectum as much as $0.5 \mu$ thick. Ektexinal surface ornamentation striate-reticulate, fingerprintlike, consisting of elongate, somewhat parallel and variously oriented muri which are connected at right angles by short muri that have slightly lower relief; the elongate muri are less than $0.5 \mu$ to $1 \mu$ high, approximately $1 / 4 \mu$ wide, with rounded to pointed tops, and approximately as far apart as their width.
Remarks.-The size range (equatorial diameter $27 \mu-49 \mu$ ) of my specimens of $P$. krempii from the Judith River Formation samples is slightly broader than that of $P$. krempii (equatorial diameter $35 \mu-42 \mu$ ) as described by Srivastava. Pulcheripollenites narcissus Srivastava (1969d, p. 61, pl. 2, figs. 28, 29), except for its larger size, appears to be very similar to $P$. krempii; and possibly, when more specimens are found, these two species will merge.

\section{Genus TRICOLPITES Cookson ex Couper, 1953 emend. Potonié, 1960}

[In part] Tricolpites Cookson ex Couper, 1953 (August), p. 61.

Tricolpites (Erdtman, 1947, Cookson, 1947, Ross, 1949) Couper, 1953 emend. Potonié, 1960, p. 95.

[In part] Tricolpites (Cookson, 1947 ex Couper, 1953) emend. Belsky, Boltenhagen, and Potonié, 1965, p. 75.

[In part] Tricolpites (Couper, 1953) Belsky, Boltenhagen, and Potonié, 1965 emend. Boltenhagen, 1967, p. 344, 346.

Tricolpites Cookson ex Couper emend, Potonié, 1960. In Srivastava, 1969d, p. 55-56.

Type Species._- (designated by Couper, 1953, p. 61) Tricolpites reticulatus Cookson, 1947, p. 134, pl. XV, fig. 45; Kerguelen Archipelago, Indian Ocean; early Tertiary.

Description (not intended as an emendation).Isopolar, tricolpate pollen grains. Shape in polar view three lobed, rounded angular, or nearly circular. Colpi slitlike to broadly gaping, with or without distinct margines. Surface of grains finely reticulate (or finely areolate) ; lumina of reticulum less than $1 \mu$ in diameter. (See Srivastava, 1969d, p. 55-56.)

Remarks.-Tricolpites, though validly published by Couper in August 1953, was virtually synonymous with the broadly circumscribed genus Tricolpopollenites Pflug and Thomson (in Thomson and Pflug, 1953, p. 95) which was validly published in March 1953. The genus Tricolpites was reinstated by Potonié in 1960, when it was restricted to spherical to ovoid isopolar tricolpate forms having bulged (convex) mesocolpia, wide furrows with thickened margins, a more or less three-lobed equator, and finely reticulate exine. Belsky, Boltenhagen, and Potonié (1965, p. 75) reemended and expanded Tricolpites to include strongly reticulate forms without thickened colpal margins and with spheroidal to ball shape. Boltenhagen (1967, p. 346) recommended emending Tricolpites to take in striate grains as well as those of other sculptures. Tricolpites as emended by Belsky, Boltenhagen, and Potonié and as recommended by, Boltenhagen is not clearly defined and would overlap other more exactly defined tricolpate pollen genera. In this report Tricolpites sensu Potonié, 1960 is accepted. 
Tricolpites reticulatus Ciookson, 1947

Plate 8, figures 29-31; table 1, No. 24

Tricolpites reticulata Cookson, 1947, p. 134.

Tricolpites reticulatus Cookson, 1947. In Couper, 1953, p. 61. [not] Retitricolpites microreticulatus (Van der Hammen) Van der Hammen and Wymstra, 1964, p. 234, pl. II, fig. 1.

Tricolpites microreticulatus Belsky, Boltenhagen, and Potonié, 1965, p. 75-76, pl. 12, fig:s. 8, 9; Mandji-Halbinsel, Gabun, Equatorial Africa, Late Cretaceous. (According to a written communication from the publisher, the date of issue of the "Paläontological Zeitschrift" in which this species was published wais July 9, 1965).

Tricolpites interangulus Newman, 1965, p. 10-11, pl. 1, fig. 3 ; Routt County, Colo.; basal part of Williams Fork Formation; Campanian. (According to a written communication from the publisher, the date of release of the publication in which this species was published was July 22, 1965.)

Tricolpites microreticulatus Belsky, Boltenhagen, and Potonié, 1965. In Srivastava, 1966, p. 548, pl. VII, fig. 24, Scollard, Alberta, Canada; Maestrichtian.

[not] Tricolpites reticulatus Cookson, 1947. In Srivastava, 1966 , p. 547, pl. VII, figs. 17-19, 26; Scollard, Alberta, Canada; Maestrichtian.

Retitricolpites microreticulatus (Belsky, Boltenhagen, and Potonié) Brenner, 1968, p. 366, pl. VIII, fig. 5; northeastern Peru; Turonian, middle Cretaceous.

Tricolpites reticulatus Cookson. In Norton and Hall, 1969, p. 43-44, pl. 7, fig. 1; Garfield County, Mont.; Hell Creek Formation; Late Cretaceous.

Tricolpites reticulatus Cookson, 1947. In Oltz, 1969, p. 141; pl. 41, fig. 103; east-central Montana; Fox Hills Sandstone and Hell Creek Formation; Maestrichtian; Tullock Member of Fort Union Formation; Paleocene.

Gunnera microreticulata (Belsky, Boltenhagen, and Potonié, 1965) Leffingwell, 1971, p. 37, pl. 6 figs. 7, 8; eastcentral Wyoming; Lance Formation, Maestrichtian.

Holotype.-In Cookson, 1947, p. 134, pl. XV, fig. 45; Kerguelen Archipelago, Indian Ocean; early Tertiary.

Remarks.-Pollen grains from the Oldman Formation (Upper Cretaceous) of western Canada called Tricolpopollenites liblarensis (Thomson) Thomson and Pflug by Rouse (1957, p. 367, pl. III, figs. 62, 63) are also probably equal to the species $T$. reticulatus.

T. reticulatus Cookson (1947); T. microreticulatus Belsky, Boltenhagen, and Potonié (1965); and $T$. interangulus Newman (1965) are characterized by deeply cut interangular colpi, round to rounded triangular shape (in polar view), and finely reticulate sculpture - the original clescriptions and illustrations of these species indicate that they are not clearly distinguishable from each other. I believe they should be considered synonymous species until or unless they can be shown by electron microscopy, or by other means, to be different from each other.

Leffingwell's (1971, p. 37, pl. 6, figs. 7, 8) speci- mens from the Lance Formation of east-central Wyoming which he assigned to Gunnera microreticulata (Belsky, Boltenhagen, and Potonié, 1965) Leffingwell appear to be extremely fine textured and this appearance in part at least is probably due to the photographic method used. For example, in our laboratory, specimens of $T$. reticulatus that have been photographed under high dry magnification appear to be more finely sculptured and have less distinctly defined texture than the same specimens photographed under high-magnification oil immersion.

Description.-Tricolpate isopolar pollen grains; shape in polar view three lobed, rounded triangular, or nearly circular; outline in equatorial view ellipsoidal to nearly circular; equatorial diameter $21 \mu-$ $32 \mu$, polar axis $23 \mu-28 \mu$. Apertures (as seen in polar view of grains): Colpi extending approximately two-thirds the distance to poles; slitlike, V-shaped, or broadly gaping; bordered by narrow margines (in some specimens margines are indistinct) ; colpi interangular, or (on nearly circular specimens) symmetrically arranged around equator. Pollen wall (as observed under $\times 1000$ oil immersion magnification): Wall $0.5 \mu-1 \mu$ thick, slightly thicker in polar areas (as seen in equatorial view of grains). Wall at equator of most specimens slightly thicker near colpi (as seen in polar view of grains). Ektexine columnar, tectate, two to three times thicker than endexine. Ektexinal sculpture finely reticulate, lumina less than $0.5 \mu$ in diameter. (It would be desirable to examine this species with the aid of a scanning electron microscope. The surface sculpture appears to be finely reticulate at high focal level, but it is possible that this is a negative reticulum.) Surface of grains under high dry magnification appearing smooth to slightly rough. Some specimens (in polar view) having distinct and variously shaped, or indistinct darkened polar areas.

Remarks.-T. reticulatus is a variable species and, on the basis of differences in size, shape of grains, coarseness of ornamentation, and presence or absence of polar thickenings (dark areas), it might conceivably be subdivided into several different species or varieties. However, observations of many specimens from a wide range of localities and ages (Trinidad Sandstone of northeastern New Mexico, Mitten Black Shale Member of Pierre Shale and Lance Formation of east-central Wyoming, Hell Creek Formation of northeastern Montana, Judith River Formation of north-central Montana, and basal part of Williams Fork Formation of northwestern Colorado (Newman's type locality of $T$. interangulus)) have shown that the morphological 
characteristics intergrade to such an extent that a subdivision does not seem to be feasible. I have also been unable to correlate any of the morphological characteristics with geographic locality or geologic age.

\section{Tricolpites hians Stanley, 1965}

Plate 8, figures $32-34$; table 1 , No. 25

Tricolpites hians Stanley, 1965, p. 321-322.

Tricolpites parvus Stanley, 1965, p. 322, pl. 47, figs 28-31.

Holotype.-In Stanley, 1965, p. 321-322, pl. 47, fig. 24; Harding County, S. Dak.; Ludlow Member of Fort Union Formation; Paleocene.

Description.-Tricolpate isopolar pollen grains; outline in polar view nearly circular, with three evenly spaced V-shaped to widely gaping colpi ; outline in equatorial view ellipsoidal; equatorial diameter $15 \mu-22 \mu$, polar axis $18 \mu-24 \mu$. Apertures: Colpi simple, long, without margines; apocolpia small. Pollen wall: Wall $1 \mu-1.5 \mu$ thick. Endexine comparatively thick; in intercolpal areas (as seen in polar views of grains) endexine approximately as thick as ektexine but thins to very thin near colpi. Ektexinal elements visible at $\times 1000$ oil-immersion magnification, consisting of microclavae. Surface sculpture at high focal level microreticulate under oil immersion $(\times 1000)$, surface of grains appearing nearly smooth at $\times 450$ magnification.

Remarks.-The specimens described above appear to be the species Tricolpites hians (and Tricolpites parvus) as illustrated by Stanley (1965, pl. 47, figs. 24-26, 28-31). Many of the specimens illustrated by Elsik (1968b, pl. 23, figs. 13-16, 18 and pl. 24, figs. 1-4, 8-14) under the name Tricolpopollenites hians (Stanley) Elsik do not appear to be equal to Stanley's Tricolpites hians or Tricolpites parvus.

Tricolpites varius Norton in Norton and Hall (1969, p. 45, pl. 6, fig. 15) from the Fort Union Formation of Montana appears to be similar and may be equal to $T$. hians Stanley.

\section{Tricolpites spp.}

Plate 8, figures $35-37$; table 1, No. 26

Genus TRICOLPOPOLLENITES Pflug and Thomson in Thomson Pflug, 1953

Cornaceoipollenites Potonié, 1951, p. 151. (Not a valid name, genus not described until 1960 (in Potonié, 1960, p. 93).)

Tricolpopollenites Pflug and Thomson in Thomson and Pflug, 1953 (March), p. 95.

Tricolpites Cookson, 1947 ex Couper, 1953 (August), p. 61. [not] Tricolpites (Erdtman, 1947, Cookson, 1947, Ross, 1949) Couper, 1953 emend. Potonié, 1960, p. 95.

Tricolpites (Couper, 1953) Belsky, Boltenhagen, and Potonié, 1965 emend. Boltenhagen, 1967, p. 344, 346.

Type species. - Tricolpopollenites (Pollenites) parmularius (Potonié) Thomson and Pflug, 1953, p. 97; holotype in Potonié, 1934, p. 52, pl. 2, fig. 7 and pl. 6, fig. 11; Geiseltals, Germany; Eocene.

Description.-Radially symmetrical, isopolar, tricolpate pollen grains. Colpi comparatively simple, not accompanied by distinctly differentiated pores but geniculi (Thomson and Pflug, 1953, p. 41) may be present. Polar axis equal to or greater than equatorial diameter. Size of grains and sculpture various. A form genus intended to accommodate tricolpate pollen that are not assignable to more precisely circumscribed genera.

Remarks.-The form genera Tricolpopollenites Pflug and Thomson and Tricolpites Cookson ex Couper were published almost simultaneously, and both were apparently intended to embrace a wide range of tricolpate pollen species having uncertain botanical affinity. Pflug and Thomson, in March 1953 (in Thomson and Pflug, 1953, p. 95), diagnosed Tricolpopollenites as follows: (translation) "Three germinals are present. These are symmetrical to each other. Apertures are developed only as meridional colpi. The polar axis is a three numbered symmetrical axis." Pflug and Thomson divided the genus into two sections. These are: section (a) species with smooth, baculate, fossulate, or other sculptures (except echinate), and section (b) species with echinate sculpture. Tricolpopollenites was placed (see Thomson and Pflug, 1953, p. 95) in the division "Longaxones" (polar axis longer than or equal to the equatorial axis). Couper, in August 1953 (p. 61), validated the genus Tricolpites. He described it as follows: "Free, isopolar, tricolpate. Exine variable in thickness and sculpture. Size variable." Tricolpites was indistinguishable from Tricolpopollenites on the basis of shape, inasmuch as Couper included in the genus subprolate, subspheroidal, prolate-spheroidal, prolate, and spheroidal species. The two genera were not distinguishable on the basis of sculpture because both, as described, had a wide variety of surface ornamentations.

Potonié (1960, p. 95) reinstated Tricolpites, limiting it to finely reticulate forms having broad, margined furrows, and three-lobed shape. Subsequently, Belsky, Boltenhagen, and Potonié (1965, p. 75) reemended and expanded Tricolpites to include strongly reticulate forms without colpal margines and with oblate to spherical shape. Boltenhagen (1967, p. 344, 346) recommended further expansion of Tricolpites that would have made it again synonymous with Tricolpopollenites (see "Remarks," this report, p. 22).

Krutzsch (1959b, p. 143) stated that he examined Tricolpopollenites parmularius and it is tri- 
colporate. In view of Krutzsch's statement, Potonié (1966, p. 168) was of the opinion that Tricolpopollenites would not apply to tricolpate forms. Pflug and Thomson (in Thomson and Pflug, 1953, p. 41) already indicated, at the time that they described Tricolpopollenites, that a geniculus was characteristic of some species which they placed in the genus. They believed that the geniculus or equatorial nick in the colpus and in the caverna probably displays a morphological stage in the formation of a pore. I do not believe that pores in the type species of Tricolpopollenites in any way alter the usefulness of Tricolpopollenites as a form genus for tricolpate pollen, as well as for tricolporate pollen which have indistinct, underdeveloped, or uncertain pores. I believe that this was the original intended scope of the genus.

Tricolpopollenites levitas n. sp.

Plate 9, figures 1-6; table 1, No. 29

Holotype.-USGS paleobotany locality D3725-C, slide (2) at $113.2 \times 3.8$; plate 9 , figure 1 ; NW1/4, sec. 26, T. 24 N., R. 17 E.; Blaine County, Mont.; Judith River Formation (upper nonmarine part); late Campanian.

Paratype.-USGS paleobotany locality D3725-C, slide (4) at $80.9 \times 6.8$; plate 9 , figures 2 , 3; same locality data as for holotype.

Paratype.-USGS paleobotany locality D3725-C, slide (4) at $84.4 \times 11.3$, plate 9 , figure 4 ; same locality data as for holotype.

Description (based on more than 100 specimens, of which 35 were measured).-Tricolpate (rarely four-colpate) pollen grains; outline in polar view circular to rounded triangular, in equatorial view circular to broadly elliptical; equatorial diameter $16 \mu-24 \mu$, polar axis $16 \mu-26 \mu$. Apertures: As seen in polar views of grains, colpi reaching approximately two-thirds the distance to poles, bordered by narrow margines $(0.5 \mu$ or less wide) ; in some specimens colpal slits jagged or irregular, appearing eroded. As seen in equatorial views, some specimens appear to have colpi of different lengths (as in Eucommiidites); however, grains in true polar view seem to have colpi of virtually equal lengths. In both polar and equatorial views, a few specimens have been seen which appear to have equatorial pores accompanying the colpi (pl. 9, fig. 5). Pollen wall: Wall (except near colpi $1 \mu-2 \mu$ thick, in some specimens thickened at poles. Ektexine two to four times thicker than endexine, in some specimens wall layers almost indistinguishable; as seen on equator (in polar views of grains), the wall grad- ually thins to $0.5 \mu$ or less near colpi; ektexine not ornamented, surface smooth.

Remarks.-The species name levitas (evenness of surface) was chosen for this taxon because of its smooth surface texture.

Comparison.-In general appearance, some specimens of Tricolpopollenites levitas resemble Eucommiidites troedssonii Erdtman (1948, p. 266, figs. 13-15) and Eucommiidites minor Groot and Penny (1960) as illustrated by Hughes (1961, pl. 37, figs. $17,18)$. Consideration was given to placing this new species in the genus Eucommiidites because it does have some characteristics in common with members of that genus; for example, its jagged edged colpi (jagged slits were mentioned by Couper, 1958 , p. 160 , for E. troedssonii) and the thinning of its equatorial exine near the colpi (mentioned for E. troedssonii by Erdtman, 1948, p. 268 and shown in his diagrams, p. 266, figs. 4, 8). However, $T$. levitas does not conform to the genus Eucommiidites as it was interpreted by Couper (1958, p. $160)$ or by Hughes (1961, p. 292). Couper described Eucommiidites as having one colpus generally better developed than the other two; and Hughes, in his description, referred to one flat face having a long furrow and the opposite more convex face bearing a ring-furrow. On the contrary, $T$. levitas has three symmetrically arranged equal colpi.

Some specimens of T. levitas resemble Hedlund's illustrations of Tricolpites erugatus (Hedlund, 1966, pl. 9, figs. 2a, 2b) ; however, the shorter colpi and distinctive colpal margines of T. levitas distinguish the species from $T$. erugatus.

\footnotetext{
Tricolpopollenites tessellatus n. sp.

Plate 9, figures 7, 8; table 1, No. 30
}

Holotype.-USGS paleobotany locality D3725-E, slide (2) at $107.6 \times 8.9$; plate 9 , figure $8 ; \mathrm{NW}^{1 / 4}$, sec. 26, T. 24 N., R. 17 E.; Blaine County, Mont.; Judith River Formation (upper nonmarine part); late Campanian.

Description (based on many specimens, 28 of which were measured).--Isopolar, tricolpate pollen grains; outline in polar view circular, with three evenly spaced colpal incisions; outline in equatorial view narrowly to broadly ellipsoidal; equatorial diameter $8 \mu-21 \mu$, polar axis $13.5 \mu-21 \mu$. Apertures: Colpi siltlike to gaping, reaching two-thirds to threefourths the distance to poles (as seen in polar view of grains). Pollen wall: Wall approximately $0.5 \mu$ thick, ektexine two to three times thicker than endexine, in many specimens wall layers not discernible. Ektexinal ornamentation consisting of helter-skelter groups of parallel muri; muri typi- 
cally $1.5 \mu-3 \mu$ long, less than $0.5 \mu$ wide, and less than $0.5 \mu$ high; muri in groups of three or four, individual muri parallel to each other and spaced approximately as far apart as their width; groups of parallel muri oriented in various directions over surface of grains to form a mosaiclike pattern.

Remarks.-This taxon was given the species name tessellatus because of its tessellated, checkered, or mosaic surface ornamentation. It was assigned to the heterogeneous form genus Tricolpopollenites because I do not believe that this single species warrants the erection of a new genus. Perhaps at a later date a more appropriate niche will be found for this new species. It does not pertain to the striate genera Striatopollis Krutzsch (1959b, p. 142-143) which has longitudinal striations (parallel to polar axis or to Aesculiidites Elsik (1968b, p. 632) which has circumstriate ornamentation.

Comparison with other species.-I have not seen any fossil grains or found in the literature any pollen with ornamentation comparable to that of $T$. tessellatus. This species with its variously oriented groups of parallel muri is distinctly different from Aesculiidites (Tricolpites) circumstriatus (Fairchild in Stover, Elsik, and Fairchild) Elsik $(1968 \mathrm{~b}$, p. 632,634$)$ which has circumstriate ornamentation, from Striatopollis sarstedtensis Krutzsch (1959b, p. 143-144) which has striations parallel to its polar axis, and from Grewipollenites canadensis Srivastava (1969d, p. 61) which has striae dispersed radially from centers.

Genus CRANWELLIA Srivastava, 1966

Cranwellia Srivastava, 1966, p. 537.

Type species.-Cranwellia (Elytranthe) striata (Couper, 1953) Srivastava, 1966, p. 537-538; holotype illustrated in Couper, (1960, pl. 8, fig. 15; Mataura Valley, New Zealand; Waitakian Stage; middle Oligocene.

Remarks.-Srivastava proposed the genus Cranwellia to accommodate fossil pollen grains which show a similarity or affinity with the pollen of the extant genus Elytranthe. He assigned the genus to the family Loranthaceae. Cranwellia is used here as a form genus because, even though the species assignable to it show some resemblance to members of the genus Elytranthe, I am not sure that they are assignable to the family Loranthaceae.

Cranwellia rumseyensis Srivastava, 1966

Plate 9, figure 9; table 1, No. 57

Cranwellia mumseyensis Srivastava, 1966, p. 538.

Holotype.-In Srivastava, 1966, p. 538, pl. XI, figs. 3, 7; Scollard area, Alberta, Canada; upper part of Edmonton Formation; Maestrichtian.

\section{Cranwellia bacata Srivastava, 1969d}

Plate 9, figures 10-12; table 1, No. 31

Cranwellia bacata Srivastava, 1969d, p. 51.

Holotype.-In Srivastava, 1969d, p. 51, pl. 1, fig. 2; Drumheller locality, Alberta, Canada; lower member of Edmonton Formation; Maestrichtian.

cf. Cranwellia

Plate 9, figure 13; table 1, No. 58

Genus FIBULAPOLLIS Chlonova, 1961

Fibulapollis Chlonova, 1961, p. 87.

Fibulapollis Chlonova, 1961. In Tschudy, 1969, p. A13.

Type species.-Fibulapollis (Triporina) mirificus (Chlonova, 1957) Chlonova, 1961, p. 87.

\footnotetext{
Fibulapollis scabratus Tschudy, 1969

Plate 9, figures 14-16; table 1, No. 75
}

Fibulapollis scabratus Tschudy, 1969, p. A13-A14, pl. 16, figs. 11-20.

Holotype.-In Tschudy, 1969, p. A13, pl. 16, fig. 11; Colville River, Alaska; Colville Group; Late Cretaceous.

\section{Genus AQUILAPOLLENITES Rouse, 1957}

Aquilapollenites Rouse, 1957, p. 370.

Type species.-A quilapollenites quadrilobus Rouse, 1957, p. 371; holotype in Radforth and Rouse, 1954, pl. I, fig. 14 ; Alberta, Canada; Brazeau Formation; Late Cretaceous.

Remarks.-Aquilapollenites as used here encompasses only those species having gross morphological characteristics (three equatorial protrusions; and two unequal polar protrusions such as those of $A$. quadrilobus, or two more or less equal polar protrusions such as those of $A$. trialatus) which correspond to those of the two original species which were assigned to the genus by Rouse. Subsequent to its inception Aquilapollenites has been emended, subdivided, and variously interpreted by many authors, including Funkhouser (1961, p. 193-194), Stanley (1961, p. 338, 340), Chlonova (1961, p. 8283), Mtchedlishvili (in Samoilovitch and others, 1961, p. 209), Belsky, Boltenhagen, and Potonié (1965, p. 80-81), Srivastava (1968a, p. 668-670), Krutzsch (1970, p. 104, 109), Srivastava and Rouse (1970, p. 1592-1593), and Tschudy and Leopold (1971, p. 120-124). The emendations and subdivisions in part have merit but I do not believe any of them are entirely satisfactory.

In this report, Mancicorpus, as restricted by Krutzsch (1970, p. 104-106), is recognized as a useful genus because it is distinct from Aquilapollenites Rouse; however, Mancicorpus, as introduced by Mtchedlishvili (in Samoilovitch and others, 1961, p. 218-219) or as emended by Srivastava (1968a, 
p. 695-697), is not acceptable because some of the species included in it are extremely similar to the type species of Aquilapollenites. As discussed earlier (Tschudy and Leopold, 1971, p. 120-121), several genera proposed by Mtchedlishvili that included species earlier described under Aquilapollenites are not acceptable because they are not clearly distinct from each other or from Aquilapollenites. Krutzsch's new genus, Hemicorpus Krutzsch (1970, p. 104, 107 ), is not acceptable because it is not distinct from Aquilapollenites; in fact, I believe its type species, Hemicorpus (Aquilapollenites) pulcher (Funkhouser) Krutzsch (1970, p. 107), is synonymous with $A$. quadrilobus, the type species of $A q u i$ lapollenites. Krutzsch's limitation of Aquilapollenites to isopolar and subisopolar species is probably based on his misunderstanding of the type species of the genus-Krutzsch (1970, p. 109) cited Rouse (1957, pl. II, fig. 9) as the type of A. quadrilobus but that figured specimen is not the holotype specimen designated by Rouse.

\section{Aquilapollenites quadrilobus Rouse, 1957}

Plate 9, figures 17, 18; table 1, No. 32

Aquilapollenites quadrilobus Rouse, 1957, p. 371.

Aquilapollenites quadrilobus Rouse, 1957. In Srivastava and Rouse, 1970, p. 1597-1598, pl. I, figs. 3-7.

Aquilapollenites quadrilobus Rouse, 1957. In Tschudy and Leopold, 1971, p. 125-127, 130-131, pl. I, figs. 5A, B and pl. 2, figs. 1A, B (holotype, two levels), 2-6.

Holotype.-In Radforth and Rouse, 1954, pl. I, fig. 14; Alberta, Canada; Brazeau Formation; Late Cretaceous.

\section{Aquilapollenites senonicus (Mtchedlishvili) Tschudy and Leopold, 1971}

Plate 9, figure 19 ; table 1, No. 65

Mancicorpus senonicum Mtchedlishvili in Samoilovitch and others, 1961, p. 224-225.

Aquilapollenites senonicus (Mtchedlishvili) Tschudy and Leopold, 1971, p. 131-132, pl. 1, fig. 2.

Holotype.-In Samoilovitch and others, 1961, p. 224-225, pl. 72, figs. 2a-c; western Siberian lowlands; lower Symian subsuite; Senonian.

Aquilapollenites trialatus Rouse var. uniformis Tschudy and Leopold, 1971 Plate 9, figure 20 ; table 1, No. 33

Aquilapollenites trialatus Rouse var. uniformis Tschudy and Leopold, 1971, p. 145, 148.

Holotype.-In Tschudy and Leopold, 1971, p. 145, pl. 4, figs. 8A, B; Niobrara County, Wyo.; Mitten Black Shale Member of Pierre Shale; middle or early Campanian.

Aquilapollenites clarireticulatus (Samoilovitch) Tschudy, 1969

Plate 9, figure 21; table 1, No. 71

Integricorpus clarireticulatus Samo:lovitch, 1965, p. 123-124.
Aquilapollenites clarireticulatus (Samoilovitch) Tschudy, 1969 , p. A6, A7.

Holotype.-In Samoilovitch, 1965, p. 123-124, figs. 2a, b; Linde River, Yakutia, U.S.S.R.; top of Chirimyian suite; Maestrichtian-Danian.

Aquilapollenites trialatus Rouse, 1957

Plate 9, figures 22-24; table 1, No. 76

Aquilapollenites trialatus Rouse, 1957, p. 371.

Aquilapollenites trialatus Rouse, 1957. In Tschudy, 1969, p. A7, pl. 4, figs. 1-5; northern Alaska; Colville Group; Late Cretaceous.

Aquilapollenites trialatus Rouse, 1957. In Srivastava and Rouse, 1970, p. 1598-1599, figs. 8-17 (specimens from type locality).

Aquilapollenites trialatus Rouse var. trialatus. In Tschudy and Leopold, 1971, p. 144.

Holotype.-In Rouse, 1957, p. 371, pl. II, fig. 14; south-central Alberta, Canada; Oldman Formation; Santonian, Late Cretaceous.

\section{Aquilapollenites reticulatus (Mtchedlishvili) Tschudy and Leopold, 1971}

Plate 9, figure 25; table 1, No. 77

Parviprojectus reticulatus Mtchedlishvili in Samoilovitch and others, 1961, p. 226-227.

Aquilapollenites reticulatus (Mtchedlishvili) Tschudy and Leopold, 1971, p. 149-151.

Holotype.-In Samoilovitch and others, 1961, p. 226-227, pl. 73, figs. 2a-c; Sym River, western Siberian lowlands; upper Symian subsuite; Maestrichtian-Danian.

\section{Aquilapollenites sp. \\ Plate 9, figures 26; table No. 34 \\ Aquilapollenites turbidus Tschudy and Leopold, 1971 \\ Plate 10, figures 1, 2; table 1, No. 59}

Aquilapollenites turbidus Tschudy and Leopold, 1971, p. 157159, pl. 1, fig. 6 , and pl. 2, figs. 7A-10.

Holotype.-In Tschudy and Leopold, 1971, p. 157159, pl. 2, figs. 7A, B; Black Hills area, Niobrara County, Wyo.; Red Bird Silty Member of Pierre Shale; middle Campanian.

\section{Aquilapollenites attenuatus Funkhouser, 1961 \\ Plate 10, figures $3-6$; table 1 , No. 35}

Aquilapollenites attenuatus Funkhouser, 1961, p. 194, 196.

Triprojectus dispositus Mtchedlishvili in Samoilovitch and others, 1961, p. 205-206, pl. 65, figs. la-c; Sym River, western Siberian lowlands; Maestrichtian-Danian.

Aquilapollenites asper Mtchedlishvili in Samoilovitch and others, 1961, p. 213, pl. 68, figs. 2a-c; Sym River, western Siberian lowlands; Maestrichtian-Danian.

Aquilapollenites granulatus Mtchedlishvili in Samoilovitch and others, 1961, p. 212, pl. 68, figs. 1a-c; Vakh River, western Siberian lowlands; early Maestrichtian.

Aquilapollenites amplus Stanley, 1961, p. 342, 344, 346, pl. 1, figs. 1-6; Harding County, S. Dak.; Hell Creek Formation; Maestrichtian. 
Aquilapollenites matsumotoi Takahashi, 1964, p. 252-253, pl. 38, figs. 1a, b; Hokkaido, Japan; lower Hokobuchi Formation; Campanian.

Aquilapollenites accipiteris Srivastava, 1969a, p. 133-134, pl. I, figs. 3-5; Alberta, Canada; Edmonton Formation; Maestrichtian.

Aquilapollenites ascriptivus Srivastava, $1969 \mathrm{a}$, p. 136, pl. II, figs. 12-15; Alberta, Canada; Edmonton Formation; Maestrichtian.

Aquilapollenites augustus Srivastava, $1969 \mathrm{a}$, p. 137, pl. III, figs. 18-20; Alberta, Canada; Edmonton Formation; Maestrichtian.

Aquilapollenites hispidus Srivastava, 1969a, p. 139-140, pl. V, figs. 31, 32; Alberta, Canada; Edmonton Formation; Maestrichtian.

Aquilapollenites regalis Srivastava, 1969a, p. 142, pl. VI, figs. 42, 43; Alberta, Canada; Edmonton Formation; Maestrichtian.

Holotype.-In Funkhouser, 1961, p. 194, 196, pl. 2, figs. 1a-c; west flank of Rawlins uplift, Rawlins, Wyo.; Lance Formation; Maestrichtian.

Description (based on Funkhouser's holotype specimen and on more than 100 specimens from Judith River Formation samples and from many additional USGS paleobotany locality samples).Tricolpate, isopolar to subisopolar pollen grains with three equatorial protrusions. In equatorial view: Polar axis $40 \mu-84 \mu$ (commonly $50 \mu-55 \mu$ ), equatorial diameter (including equatorial protrusions) $43 \mu-93 \mu$ (commonly $55 \mu-63 \mu$ ), diameter of body $11 \mu-42 \mu$ (commonly $17 \mu-23 \mu$ ), diameter of equatorial protrusions $11 \mu-22 \mu$ (commonly $14 \mu-$ $18 \mu)$, length of equatorial protrusions $15 \mu-34 \mu$ (commonly $20 \mu-25 \mu$ ). Shape of body oval; diameter of polar protrusions usually greater than, or in some specimens equal to or less than, the diameter of equatorial protrusions; length of polar protrusions usually approximately equal to, or in some specimens slightly greater or less than length of equatorial protrusions; polar protrusions and equatorial protrusions broadly rounded at their ends. In polar view: Shape of grains triangular, with extended rounded corners and slightly concave sides; free ends of equatorial protrusions paddle shaped, flattened in plane parallel to polar axis of grain. Apertures: Colpi dissecting equatorial protrusions, extending a short distance onto body, sometimes gaping at free ends of equatorial protrusions. Pollen wall: Exine two layered; endexine (except for endexinal costae) usually less than $0.5 \mu$ thick. Axillary endexinal costae bow shaped to lens shaped, extending one-half to twothirds the length of equatorial protrusions and extending onto base of polar protrusions, costae as much as $3 \mu$ thick in thickest part; in some specimens costae very distinct, in others faintly visible or absent (where absent probably were removed by chemical treatment during removal of grains from rock matrix). Ektexine approximately $1 \mu$ thick; ektexinal elements columnar, their diameter approximately equal to the distance between them, fused at tips in partial tectum resulting in a foveolate to reticulate appearance of surface of grains. Conical spines extending $1.5 \mu-2.5 \mu$ above surface of tectum, ornamenting surface of grain; spines mainly restricted to polar domes, tips of equatorial protrusions, equatorial areas, and colpal margins (along edges of equatorial protrusions in equatorial view of grains). Spines on polar protrusions oriented perpendicular to surface, on equatorial protrusions usually oriented toward polar axis of grain, at colpal margins spines retroflexed (pointing toward polar axis of grain). Spines at ends of equatorial protrusions not conspicuously larger than those on rest of grain.

Remarks.-Funkhouser described A. attenuatus as a tridemicolpate pollen species. I have examined the holotype specimen and believe that the demicolpi referred to by Funkhouser are thin areas from which endexinal costae have partially dissolved. Colpi are clearly visible in many of the specimens that I have seen; they are, as a rule, most apparent in polar and oblique views of grains.

The new description of $A$. attenuatus presented above is not considered an emendation but is merely meant to clarify and expand the species in the light of present knowledge and greater abundance of specimens. A. attenuatus as here amplified consists of grains of a wide but gradational size range and grains with much variation in proportional length and width of polar and equatorial protrusions. In one USGS paleobotany locality sample (D3012 from the Bearpaw Shale of Montana) about 40 specimens were examined. In this sample there were grains closely resembling the holotype specimen of $A$. attenuatus and also large to small grains with proportionally larger bodies and smaller equatorial protrusions than the holotype. Some specimens in this sample had unequal polar protrusions (subisopolar). Sculpture also varied. Another USGS paleobotany sample (D1331 from the Fox Hills Sandstone from Wyoming), though containing a smaller number of specimens, also provided grains having widely variable form. I have attempted to separate our large number of specimens into varieties of $A$. attenuatus but have concluded that variants intergrade and cannot be distinctly or reliably separated from each other.

Similar species._-Triprojectus" unicus (Chlonova) Mtchedlishvili (in Samoilovitch and others, 1961, p. 206-207, pl. 66, figs. 1a-c) and "Tripro- 
jectus" crassus Mtchedlishvili (in Samoilovitch and others, 1961, p. 207-208, pl. 66, figs. 2a-c, 3) are similar to $A$. attenuatus but differ by having more slender equatorial protrusions.

Aquilapollenites insignis Mtchedlishvili (in Samoilovitch and others, 1961, p. 215-216, pl. 69, figs. $1 \mathrm{a}-\mathrm{c}, 2,3$ ) closely resembles $A$. attenuatus but possibly it can be distinguished because in the illustrations (drawings) A. insignis appears to have knoblike projections instead of spines on the ends of the equatorial protrusions.

Aquilapollenites subtilis Mtchedlishvili (in Samoilovitch and others, 1961, p. 214, pl. 68, figs. 3a-c, 4) differs from $A$. attenuatus in its uniform distribution of spines over the entire surface of the pollen grain.

Aquilapollenites latilobus Mtchedlishvili (in Samoilovitch and others, 1961, p. 216, pl. 69, figs. 4ac) differs from $A$. attenuatus in its distinctly coarser reticulum on the polar areas.

Aquilapollenites aucellatus Srivastava (1969a, p. 136-137,, pl. III, figs. 16, 17) and Aquilapollenites drumhellerensis Srivastava (1969a, p. 138, pl. IV, fig. 28) appear to be similar to $A$. attenuatus but can be differentiated from it because of their more abundant and smaller spines in the equatorial areas.

Genus MANCICORPUS Mtchedlishvili, pro parte, Krutzsch, 1970

[in part] Mancicorpus Mtchedlishvili in Samoilovitch and others, 1961, p. 218-219.

Mtchedlishvilia Srivastava, 1969c, p. 615-616.

Mancicorpus Mtchedlishvili, pro parte Krutzsch, 1970, p. 103, 105-106.

Type species.-Mancicorpus anchoriforme Mtchedlishvili in Samoilovitch and others, 1961, p. 219-220, pl. 70, figs. 3a-c; Sym River, western Siberian lowland; upper Symian subsuite; Maestrichtian-Danian.

New combination. - Mancicorpus (Mtchedlishvilia) canadianus (Srivastava, 1969c, p. 616, 618, pl. I, figs. 1-8; Alberta, Canada; Edmonton Formation; Maestrichtian) n. comb.

Remarks.-Mancicorpus as restricted by Krutzsch is distinct from Aquilapollenites and is therefore a useful form genus. Krutzsch included in Mancicorpus only forms that have a tripodal shape-forms having one concave or flat pole and one convex but not prominent pole. The remaining four species that Mtchedlishvili originally described and included in Mancicorpus-species that have one major polar protrusion and one much smaller or nodelike protrusion-were placed by Krutzsch in his new genus Hemicorpus. Hemicorpus Krutzsch (1970, p. 104), however, is here considered to be a synonym of Aquilapollenites because the type species of Hemi- corpus (Hemicorpus (Aquilapollenites) pulcher (Funkhouser) Krutzsch) is extremely similar to, and I believe synonymous with, A. quadrilobus, the type species of Aquilapollenites.

The genus Mtchedlishvilia Srivastava as circumscribed by its author is not distinguishable from Mancicorpus as it is represented by its type species, Mancicorpus anchoriforme.

Mancicorpus calvus (Tschudy and Leopold, 1971) n. comb.

Plate 10, figures 7-9; table 1, No. 37

Aquilapollenites calvus Tchudy and Leopold, 1971, p. 138140, pl. 1, fig. 4 and pl. 3, figs. 1-5.

Holotype.-In Tschudy and Leopold, 1971, p. 138140, pl. 3, fig. 1; Black Hills area, Niobrara County, Wyo. ; lower unnamed shale member of Pierre Shale; late Campanian.

Mancicorpus tripodiformis (Tschudy and Leopold, 1971) n. comb.

Plate 10, figures 10, 11; table 1, No. 60

Aquilapollenites tripodiformis Tschudy and Leopold, 1971, p. 140-143, pl. 3, figs. 9A-10.

Holotype.-In Tschudy and Leopold, 1971, p. 140141, pl. 3, figs. 9A, B; Black Hills area, Niobrara County, Wyo.; Pierre Shale; late Campanian.

Remarks.-M. tripodiformis n. comb. is similar to Mancicorpus (Mtchedlishvilia) canadianus (Srivastava, 1969c) n. comb. but apparently is distinguishable because of the striated sculpture on its major pole and equatorial protrusions. It is possible that these two species will be found to merge and that $M$. tripodiformis will become a synonym of Mancicorpus canadianus.

\section{POLYCOLPATES}

Genus SINDORAPOLLIS Krutzsch, 1969

Sindorapollis Krutzsch, 1969, p. 413.

Type species. - Sindorapollis (Loranthacites) pilatus (Mtchedlishvili) Krutzsch, 1969, p. 413; holotype in Samoilovitch and others, 1961, p. 195, pl. 63, figs. 1a-c; western Siberian plains; Senonian.

Description._Radially symmetrical, angulaperturate pollen grains having three pairs of demicolpi which are separated at equator by equatorial bridges and at poles by polar areas (not syncolpate); demicolpi either accompanied by or not accompanied by pores. Size of grains and exine sculpture various.

New combination.-Sindorapollis (Loranthacites) catteralli (Srivastava, 1969b, p. 980, pl. II, figs. 21, 22; Alberta, Canada; Edmonton Formation; Maestrichtian) n. comb. Loranthacites Mtchedlishvili, to which the species catteralli was originally assigned, is a later homonym of Loranthacites Conwentz, (1886). 
Sindorapollis granulatus n. sp.

Plate 10, figures 12-16; table 1, No. 78

Holotype.-USGS paleobotany locality D4069, slide (1) at $106.5 \times 10.5$; plate 10 , figure 12 ; SW $1 / 4, S_{1} 1 / 4$ SW $1 / 4$ sec. 15, T. 23 N., R. 22 E.; Phillips County, Mont.; Judith River Formation; late Campanian.

Paratype.-USGS paleobotany locality D4069, slide $(2)$ at $104.3 \times 3.6$; plate 10 , figure 13 ; same locality data as for holotype.

Paratype.-USGS paleobotany locality D4069, slide (1) at $105.7 \times 18.7$; plate 10 , figure 14 ; same locality data as for holotype.

Description (based on 38 specimens in polar view and six in equatorial view).--Radially symmetrical, isopolar, angulaperturate pollen grains having three pairs of demicolpi; outline of grain in polar view rounded triangular, in equatorial view oval to rounded rhomboidal; equatorial diameter $16.5 \mu-$ $28 \mu$ (commonly $20 \mu-26 \mu$ ), polar axis $19 \mu-24 \mu$. Apertures: Demicolpi slitlike, in some specimens gaping slightly, without margines, $5 \mu-8 \mu$ long, not joining at poles, reaching to within $0.5 \mu-1.5 \mu$ of equator; occasionally the narrow bridge between demicolpi at equator is apparently torn and demicolpal slits are joined (forming a colpus). Pollen wall: Wall $0.5 \mu-1 \mu$ thick; endexine thin, ektexine two to three times thicker than endexine; in most specimens wall at equator slightly thicker on corners than on sides of grain; ektexinal columellae very fine, not always visible even under $\times 1000$ oil-immersion magnification, tectate; at $\times 430$ high dry magnification, surface of grains appearing almost smooth; at $\times 1,000$ oil-immersion magnification, surface appearing granular.

Comparison with similar species.-Sindorapollis granulatus n. sp. differs from Sindorapollis catteralli (Srivastava) n. comb. in its smaller size, more rounded outline, shorter demicolpi, and finer sculpture.

S. granulatus differs from Sindorapollis pilatus (Mtchedlishvili) Krutzsch (1969, p. 413) in its smaller size, much finer surface sculpture, and lack of pores.

S. granulatus is smaller than Sindorapollis triangulus Kruztsch (1969, p. 413) and has siltlike simple demicolpi, whereas $S$. triangulus has demicolpi with thickened margins.

\section{TRICOLPORATES}

\section{Genus CUPANIEIDITES Cookson and Pike, 1954}

Cupanieidites Cookson and Pike, 1954, p. 210.

Cupanieidites Cookson and Pike, 1954. In Krutzsch, 1959b, p. 144-145.
Duplopollis Krutzsch, 1959b, p. 144.

Cupanieidites Cookson and Pike, 1954. In Potonié, 1960, p. 106.

Cupanieidites Cookson and Pike, 1954. In Belsky, Boltenhagen, and Potonié, 1965, p. 77.

Type species.- (selected by Krutzsch, 1959b, p. 144) Cupanieidites major Cookson and Pike, 1954, p. 213-214, pl. 2, figs. 83-85; lectotype (here selected) in Cookson and Pike, 1954, pl. 2, fig. 83; Anglesea, Victoria, Australia; Eocene.

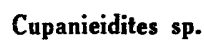

Plate 10, figure 17; table 1, No. 91

Genus TRICOLPORITES Cookson, 1947

Tricolporites Cookson, 1947, p. 134.

Type species.-Tricolporites prolata Cookson, 1947, p. 134, pl. XV, fig. 46; Waterfall Gorge (near Port Jeanne d'Arc), Kerguelen Archipelago, Indian Ocean; Tertiary.

Description.-Isopolar, tricolporate pollen grains. Polar axis greater than, or equal to, equatorial diameter. Colpi meridional, arranged symmetrically, each provided with an equatorially located well-differentiated pore. Size of grains variable. Surface smooth or nearly so-dimensions of sculptural elements less than $1 \mu$.

Remarks.-Erdtman (1947, p. 110) used the term "Tricolporites" in his system of classification of fossil and recent pollen and spores but did not use it as a genus name. Cookson (1947, p. 134) introduced Tricolporites in the generic sense when she described and illustrated the binomial Tricolporites prolata. Tricolporites Cookson was a monotypic new genus and was a valid name (see article 42 of the "International Code of Botanical Nomenclature" (Lanjouw, chm., and others, 1966).

\footnotetext{
Tricolporites rhomboides Anderson, 1960

Plate 10, figures 18-21; table 1, No. 38
}

Tricolparites rhomboides Anderson, 1960, p. 26.

Holotype.-In Anderson, 1960, p. 26, pl. 7, fig. 15; eastern side of San Juan Basin, New Mexico; Nacimiento Formation; Cretaceous-Tertiary.

Description (based on many specimens, of which 30 were measured.)-Tricolporate pollen grains; outline in polar view rounded triangular to nearly circular; outline in equatorial view rhomboidal, elliptical, or nearly circular. Equatorial diameter $16 \mu-22 \mu$, polar axis $16.5 \mu-24 \mu$. Most specimens in polar view have a triradiate compression fold on polar area (see pl. 10, fig. 18). Apertures: Colpi long, extending two-thirds to three-fourth the distance to poles, bordered by narrow (approximately $0.5 \mu$ wide) margines; pores as seen in equatorial view of grains $0.5 \mu-1 \mu$ (rarely as much as $1.5 \mu$ ) in 
diameter. Pollen wall: Wall approximately 1.5 $\mu$ thick; ektexine two to three times thicker than endexine; ektexinal columellae fused at tips in a partial tectum. Surface sculpture scabrate.

Remarks.-The grains described above, except for their slightly larger size, correspond to T. rhomboides as described and illustrated by Anderson.

\section{Tricolporites sp.}

Plate 10, figure 22; table 1, No. 96

Genus MONTANAPOLLIS Tschudy, 1971

Montanapollis Tschudy, 1971, p. B58.

Type species.-Montanapollis endannulatus Tschudy, 1971, p. B58, figs. 3, 4; Phillips County, Mont.; Bearpaw Shale (basal part) or Judith River Formation (uppermost part); late Campanian.

\section{Montanapollis endannulatus Tschudy, 1971}

Plate 11, figure 1; table 1, No. 39

Montanapollis endannulatus Tschudy, 1971, p. B58.

Holotype.-In Tschudy, 1971, p. B58, fig. 3; Phillips County, Mont.; Bearpaw Shale (basal part) or Judith River Formation (uppermost part); late Campanian.

\section{Genus SIBERIAPOLLIS Tschudy, 1971}

Siberiapollis Tschudy, 1971, p. B54.

Type species.-Siberiapollis montanensis Tschudy, 1971, p. B55, 57-58, fig. 1, 2; Fergus County, Mont.; lower marine part of Judith River Formation; late Campanian.

\section{Siberiapollis montanensis Tschudy, 1971}

Plate 11, figures 2, 3; table 1, No. 72

Siberiapollis montanensis Tschudy, 1971, p. B55.

Holotype.-In Tschudy, 1971, p. B55, a of fig. 2; Fergus County, Mont.; lower marine part, Judith River Formation; late Campanian.

\section{TRIPORATES}

Genus TRIATRIOPOLLENITES Pflug in Thomson and Pflug, 1953

Triatriopollenites Pflug in Thomson and Pflug, 1953, p. 76-77.

Type species.-Triatriopollenites rurensis Pflug and Thomson in Thomson and Pflug, 1953, p. 79, pl. 7, fig. 95 ; Eschweiler, Germany ; Miocene.

Triatriopollenites costatus Norton in Norton and Hall, 1969

Plate 11, figures 4, 5; table 1, No. 61

Triatriopollenites costatus Norton in Norton and Hall, 1969, p. 40-41.

Holotype.-In Norton and Hall, 1969, p. 40-41, pl. 5, fig. 19; Garfield County, Mont.; Hell Creek Formation; Late Cretaceous.
Genus SUBTRIPOROPOLLENITES Pflug and Thomson in Thomson ant Pflug, 1953

Subtriporopollenites Pflug and Thomson in Thomson and Pflug, 1953, p. 85.

Subtriporopollenites Pflug and Thomson 1953. In Krutzsch, 1960, p. 307-308.

Type species. - Subtriporopollenites anulatus subsp. anulatus (not subsp. notus) Pflug and Thomson in Thomson and Pflug, 1953, p. 85-86, pl. 9, fig. 49 ; middle Europe; Tertiary.

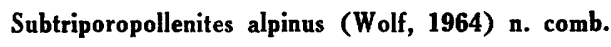

Plate 11, figures 6-8; table 1, No. 41

Triporopollenites alpinus Wolf, 1964, p. 114-115, pl. 1, figs. 8-19.

Holotype.-In Wolf, 1964, p. 114-115, pl. 1, figs. 8-10; Breitenbach on the Tegern Sea, Bavaria; Zementmergel Series; Campanian.

Description (based on 20 specimens from Judith River Formation samples).-Triporate pollen, shape in polar view convex triangular to circular, diameter $16 \mu-24 \mu$. Apertures: Pores slightly subequatorial, circular or nearly so, $1.5 \mu-2 \mu$ in diameter (or rarely as much as $3 \mu$ ), not protruding or in some specimens very slightly protruding; pore margines approximately $2 \mu$ wide, in most specimens inconspicuous, in some specimens not discernible. Pollen wall: Exine two layered, about $1 \mu$ thick, as much as $1.5 \mu$ thick in margo areas surrounding pores; endexine thin, approximately one-third as thick as ektexine; in many specimens wall layers not discernible. Surface sculpture microverrucate; verrucae $0.5 \mu-1 \mu$ in diameter, circular in outline or nearly so, $0.5 \mu$ or less in height; distance between verrucae about equal to, or less than, their diameter.

Remarks.-My specimens from the Judith River Formation appear to be very similar to $S$. alpinus (Wolf) n. comb. as it was described and illustrated by Wolf. One specimen that probably is the same species, but is slightly larger $(24 \mu \times 29 \mu)$ and has four pores, was found in the Judith River sample USGS paleobotany locality D3726-A.

Comparison with similar species.-In shape of grain and size of pores $S$. alpinus resembles Triporopollenites rugatus Newman (1965, p. 12, pl. 1, fig. 7) ; however, the two species differ in that $S$. alpinus is slightly smaller, and it has a microverrucate surface ornamentation whereas T. rugatus has a smooth to scabrate sculpture.

The sculpture of $S$. alpinus resembles that of Ulmoideipites krempii Anderson (1960, p. 20, pl. 6, fig. 2) and Ulmoideipites tricostatus Anderson (1960, p. 20-21, pl. 4, fig. 9), but S. alpinus lacks the arci which characterize those species. 
Genus PROTEACIDITES Cookson ex Couper, 1953

Proteacidites Cookson, 1950, p. 170-175. (No description of genus and no type species designated.)

Proteacidites Cookson ex Couper, 1953, p. 42.

Type species.- (designated by Couper, 1953, p. 42) Proteacidites adenanthoides Cookson, 1950, p. 172-173, pl. 2, fig. 21; Wensleydale, Australia; Tertiary.

\section{Proteacidites spp.}

Plate 11, figures 9-12; table 1, No. 42

\section{POLYPORATES}

Genus PERIPOROPOLLENITES Pfug and Thomson emend. Krutzsch, 1966

Liquidambar-pollenites Raatz, 1937, p. 17. (Not valid, no genus description.)

Periporopollenites Pflug and Thomson in Thomson and Pflug, 1953, p. 111.

Liquidambarpollenites Raatz, 1937 ex Potonié, 1960, p. 134. (Name was here validated by Potonié; however, it was a synonym of Periporopollenites which was valid in 1953-both genera had the same type species.)

Periporopollenites Pflug and Thomson emend. Krutzsch, 1966 , p. 39-40.

Type species.-Periporopollenites (Pollenites) stigmosus (Potonié) Thomson and Pflug, 1953, p. 111; holotype in Potonié, 1931a, p. 332, pl. II, fig. 1; Muskauer Braunkohle, Germany; Miocene.

Periporopollenites sp.

Plate 11, figure 13; table 1, No. 92

Genus ERDTMANIPOLLIS Krutzsch, 1962

Erdtmanipollis Krutzsch, 1962, p. 281.

Type species.-Erdtmanipollis pachysandroides Krutzsch, 1962, p. 281, pl. VIII, figs. 1-8.

\section{Erdtmanipollis pachysandroides Krutzsch, 1962 \\ Plate 11, figure 14; table 1, No. 43}

Erdtmanipollis pachysandroides Krutzsch, 1962, p. 281.

Holotype.-In Krutzsch, 1962, p. 281, pl. VIII, figs. 1-4; Spremberg, Germany; upper Chatt; late Oligocene.

Remarks.-The diameter of the specimens found in the samples from the Judith River Formation ranges from $29 \mu$ to $37 \mu$. These grains closely resemble specimens of $E$. pachysandroides as illustrated by Krutzsch (1962, pl. VIII, figs. 1-8).

\section{DYADS}

\section{Genus DYADONAPITES Erdtman, 1947 ex Tschudy (this report)}

Dyado-napites Erdtman, 1947. p. 111. (Term proposed in system of classification but not used as a genus name.)

Dyadites Pant, 1954, p. 54. (Name proposed but no species assigned.)

Dyadites van der Hammen, 1956, p. 79. (Not a valid nametype specimen designated was a recent pollen grain.)

Type species.-Dyadonapites reticulatus n. sp.
Description.-Inaperturate palynomorphs united in dyads, greatest dimension of dyad less than $60 \mu$; individual cells of dyad alike or very similar, their shape spherical, oval, or irregular; surface ornamentation various.

Comparison with similar genera.-Dyadonapites is smaller than the Liassic genus Circularesporites Danzé and Laveine $(1963$, p. 86 ; diameter $60 \mu-$ $500 \mu$ ), and its individual cells do not have circular dehiscence areas as do those of Circularesporites.

$$
\text { Dyadonapites reticulatus n. sp. }
$$

Plate 11, figures 15-17; table 1, No. 66

Holotype.-USGS paleobotany locality D3725-C, slide (4) at $85.0 \times 6.0$; plate 11 , figure $15 ; \mathrm{NW} 1 / 4$ sec. 26, T. 24 N., R. 17 E.; Blaine County, Mont.; Judith River Formation (upper nonmarine part) ; late Campanian.

Paratype.-USGS paleobotany locality D3725-C, slide (5) at $91.0 \times 17.1$; plate 11 , figure 16 ; same locality data as for holotype.

Description (based on many specimens, of which 30 were measured).--Inaperturate palynomorphs united in dyads; diameter of individual cells $14 \mu-$ $22 \mu$, shape spherical, oval, rounded angular, or irregular owing to folding. Length of dyad $23 \mu-$ $41 \mu$. Individual cells of dyad similar but in some specimens one cell slightly larger than the other one. Wall: Exine probably two layered, apparent thin endexine visible as a component of the wall in a few specimens. Ektexinal sculpture reticulate; lumina irregular in shape and variable in size, less than $0.5 \mu$ to as much as $2 \mu$ in diameter; muri delicate, less than $0.5 \mu$ wide and less than $0.5 \mu$ high; in some specimens muri appearing rough and on some well-preserved specimens this roughness can be seen to consist of microbaculae or microverrucae on the muri peaks.

Remarks.-In some preparations containing Dyadonapites reticulatus n. sp., many palynomorphs are present which appear to be individual cells of this species (see taxon 44) ; whereas, in other preparations very few free cells are present.

\section{TETRADS}

\section{Genus INAPERTUROTETRADITES van Hoeken-Klinkenberg, 1964}

Inaperturotetradites van Hoeken-Klinkenberg, 1964, p. 226.

Type species.-Inaperturotetradites lacunosus van Hoeken-Klinkenberg, 1964, p. 226, pl. VI, figs. 17a, b ; Inyi, Nigeria; Maestrichtian.

Inaperturotetradites scabratus n. sp.

Plate 11, figures 18, 19; table 1, No. 63

Holotype.-USGS paleobotany locality D3725-A, 
slide (2) at $96.3 \times 4.1$; plate 11 , figure 18 ; NW1/4 sec. 26, T. 24 N., R. 17 E.; Blaine County, Mont.; Judith River Formation (upper nonmarine part); late Campanian.

Description (based on 20 specimens).--Inaperturate pollen grains, arranged in tetrahedral tetrads. Shape of individual grains spherical or nearly so. Diameter of tetrads $29 \mu-45 \mu$, diameter of individual grains $18 \mu-27 \mu$. Exine thin, or as much as $0.75 \mu$ thick; endexine very thin, in many specimens not clearly visible. Sculptural elements consisting of small projections less than, or slightly greater than, $0.5 \mu$ high, and less than $0.5 \mu$ in diameter, spaced at intervals almost equal to their diameter; height of surface projections (scabrae) varies on individual tetrads and also on different grains of a single tetrad.

Comparison with similar species and remarks.Because 1. scabratus $n$. sp. is inaperturate, it is easily distinguishable from Dicotetradites granulatus Norton, in Norton and Hall $(1969, \mathrm{p} .53$, pl. 5, fig. 4) whose individual grains are monoporate.

I. scabratus n. sp. appears similar to Ericaceoipollenites rallus Stanley (1965, p. 296-297, pl, 44, figs. 15-18) from the Paleocene of South Dakota, except that the grains of the tetrad do not have colpi. Stanley described the grains of $E$. rallus as inaperturate to weakly tricolpate, but I have not observed colpi in any of the specimens of $I$. scabratus that I have examined. Compression folds sometimes resemble colpi but I do not interpret them as colpi. It is possible that $I$. scabratus, which I have found in the Campanian and Maestrichtian of Montana and Wyoming, will be found to be synonymous with Stanley's $E$. rallus from the Paleocene of South Dakota. Because I do not believe that my specimens have colpi, I have placed this new species in the genus Inaperturotetradites.

Stanley (1965, p. 296) interpreted the genus Ericaceoipollenites to include inaperturate to weakly tricolpate pollen grains that are arranged in a tetrahedral tetrad, and consequently he placed his new species (rallus) in that genus. He either ignored or did not agree to (but did not mention) Manum's (1962, p. 29) earlier synonymy of Ericaceoipollenites under Ericipites. I believe, as did Stanley, that Ericaceoipollenites and Ericipites were separable. Stanley (1965, p. 296) pointed out that Ericaceoipollenites is separable from Ericipites by the absence of well-defined colpi. It seems to me that the two genera were easily distinguishable on the basis that Ericaceoipollenites Potonié (1951 ex Potonié, 1960, p. 138) was described as having furrows relatively short and at times indistinct, whereas Ericip- ites Wodehouse (1933, p. 516-517) was described as having pores in addition to colpi. Manum did not emend Ericipites to include tricolpate as well as tricolporate forms. I tentatively accept Manum's synonymy because it was agreed to by Potonié (1966, p. 192), the author of Ericaceoipollenites, but I believe that Ericipites should be emended to include tricolpate in addition to tricolporate pollen.

Genus DROSERIDITES Cookson, 1947 ex Potonié, 1960

Tetradites (Droseridites) Cookson, 1947, p. 137.

Droseridites Cookson, 1947 ex Potonié, 1960, p. 139.

Type species.-Droseridites (Tetradites (Droseridites)) spinosa (Cookson, 1947) Potonié, 1960; lectotype (selected by Potonié, 1960, p. 139) in Cookson, 1947, p. 137, pl. XVI, fig. 70; Waterfall Gorge, Kerguelen Archipelago; Tertiary.

Droseridites spinulosus Manum, 1962

Droseridites spinulosus Manum, 1962, p. 30-31, pl. V, figs. 1-5.

Holotype.-In Manum, 1962, p. 30-31, pl. V, fig. 1; Spitsbergen; Tertiary.

Droseridites cf. D. spinulosus

Plate 11, figure 20; table 1, No. 93

\section{REFERENCES CITED}

Anderson, R. Y., 1960, Cretaceous-Tertiary palynology, eastern side of the San Juan Basin, New Mexico: New Mexico Bur. Mines and Mineral Resources Mem. 6, 58 p., pls. 1-11.

Balme, B. E., 1957, Spores and pollen grains from the Mesozoic of Western Australia: Commonwealth Sci. Indus. Research Organization, Coal Research Sec., no. 25, 48 p., pls. 1-11.

- 1963, Plant microfossils from the Lower Triassic of Western Australia: Palaeontology, v. 6, pt. 1, p. 12-40, pls. 4-6.

Belsky, C. Y., Boltenhagen, E., and Potonié, Robert, 1965, Sporae dispersae der Oberen Kreide von Gabun, äquatoriales Afrika: Paläont. Zeitschr., v. 39, no. 1/2, p. 72-83, pls. 12-13.

Bharadwaj, D. C., and Singh, H. P., 1964, An Upper Triassic miospore assemblage from the coals of Lunz, Austria: Palaeobotanist, v. 12 , no. 1 , p. 28-44, pls. 1-5.

Bolkhovitina, N. A., 1953, Sporovo-pyltsevoya kharakteristika melovykh otlozhenii tsentral'nykh oblastei SSSR [Sporepollen characteristics of Cretaceous deposits of the central provinces of the USSR]: Akad. Nauk SSSR Geol. Inst. Trudy, v. 145, Geol. ser. no. 61, 184 p., pls. IXVI.

- 1956, Atlas spor i ply'tsy ie iurskikh i nizhnemelovykh otlozhenii Viliuiskoi vpadiny [Atlas of spores and pollen from Jurassic and lower Cretaceous deposits of Vilyui basin]: Akad. Nauk SSSR Geol. Inst. Trudy, no. 2, p. 1-132, pls. I-XXV.

Boltenhagen, E., 1967, Spores et pollén du Crétacé Supérieur du Gabon: Pollen et Spores, V. 9, no. 2, p. 335-355, pls. I-V. 
Brenner, G. J., 1963, The spores and pollen of the Potomac Group of Maryland: Maryland Dept. Geology, Mines, and Water Resources Bull. 27, 215 p., pls. 1-43.

1968, Middle Cretaceous spores and pollen from northeastern Peru; Pollen et Spores, v. 10, no. 2, p. 341-383, pls. I-X.

Burger, D., 1966, Palynology of uppermost Jurassic and lowermost Cretaceous strata in the eastern Netherlands: Leidse Geol. Meded., v. 35, p. 209-276, pls. 1-39.

Chlonova, A. F., 1957, O vydekenii rukovodiashchikh vidov pri opredelenii vozrasta otlozhenii po sporovo-pyt'tsevomv analizu [On identification of the index species in the determination of the age of deposits by spore-pollen analysis]: Akad. Nauk SSSR Vostoch. Fil. Izv., no. 2, p. $43-46$, pl. I.

1960, Vidovi sostav pyl'tsy i spor $v$ otlozheniiakh verghego mela Tchulymo-Eniseiskoi vpadiny [Species composition of pollen and spores from Upper Cretaceous deposits of the Chulimo-Yenisei depression]: Akad. Nauk SSSR Sibirsk. Otdeleniye Inst. Geologii i Geofiziki Trudy, v. 3, 104 p., pls. I-X.

- 1961, Spory i ply'tsa verkhnei poloviny verkhnego mela vostochnoi chasti Zapadno-Sibirskoi nizmennosti [Spores and pollen from the upper half of the Upper Cretaceous of the eastern part of the western Siberian depression]: Akad. Nauk SSSR Sibirsk. Otdeleniye Inst. Geologii i Geofiziki Trudy, v. 7, 140 p., pls. I-XVII.

- 1962, Some morphological types of spores and pollen grains from Upper Cretaceous of eastern part of the west Siberian lowland: Pollen et Spores, v. 4, no. 2, p. 297-309, pls. I-IV.

Cookson, I. C., 1947, Plant microfossils from the lignites of Kerguelen archipelago: British, Australia, and New Zealand Antarctic Research Exped. Rept., ser. A., v. 2, p. 127-142, pls. XIII-XVII.

1950, Fossil pollen grains of proteaceous type from Tertiary deposits in Australia: Australian Jour. Sci. Research, ser. B-Biol. Sci., v. 3, no. 2, p. 166-177, pls. 1-3.

1953a, The identification of the sporomorph Phyllocladidites with Dacrydium and its distribution in southern Tertiary deposits: Australian Jour. Botany, v. 1, no. 1, p. 64-70, pl. 1 .

- 1953b, Difference in microspore composition of some samples from a bore at Comaum, South Australia: Australian Jour. Botany, v. 1, no. 3, p. 462-473, pls. $1,2$.

Cookson, I. C., and Dettmann, M. E., 1958, Some trilete spores from upper Mesozoic deposits in the eastern Australian region: Royal Soc. Victoria Proc., v. 70, pt. 2, p. 95-128, pls. XIV-XIX.

Cookson, I. C., and Pike, K. M., 1954, Some dicotyledonous pollen types from Cainozoic deposits in the Australian region: Australian Jour. Botany, v. 2, no. 2, p. 197219 , pls. $1,2$.

Couper, R. A., 1953, Upper Mesozoic and Cainozoic spores and pollen grains from New Zealand: New Zealand Geol. Survey Paleont. Bull, 22, 77 p., pls. 1-9.

- 1958, British Mesozoic microspores and pollen grains -A systematic and stratigraphic study: Palaeontographica, ser. B, v. 103, nos. 4-6, p. 75-179, pls. 15-31.

1960, New Zealand Mesozoic and Cainozoic plant microfossils: New Zealand Geol. Survey Paleont. Bull 32 , p. $1-87$, pls. $1-12$.
Danzé, J., and Laveine, J. P., 1963, Étude palynologique d'une argile provenant de la limite Lias-Dogger, dans un sondage à Boulogne-sur-Mer: Soc. Géol. Nord Annales, v. 83, p. 79-90, pls. XIII-XVI.

Daugherty, L. H., 1941, The Upper Triassic flora of Arizona: Carnegie Inst. Washington Pub. 526, 108 p., pls. 1-34.

Delcourt. A. F., Dettmann, M. E., and Hughes, N. F., 1963, Revision of some Lower Cretaceous microspores from Belgium: Palaeontology, v. 6, pt. 2, p. 282-292, pls. $42-45$.

Delcourt, A. F., and Sprumont, G., 1955, Les spores et grains de pollen du Wealdien du Hainaut: Soc. Belge Géologie, Paléontologie et Hydrologie Mém., new ser., no. 5, 73 p., pls. I-IV.

- 1957, Quelques microfossiles du Wealdien de FeronGlageon: Soc. Belge Geologie, Paleontologie et Hydrologie Bull., v. 66, no. 1, p. 57-67, pls. I-III.

- 1959, Spores, grains de pollen, Hystrichosphères et Péridiniens dans le Wealdien de Féron-Glageon: Soc. Geol. Nord Annales, v. 79, p. 29-64, pls. III-VII.

Dettmann, M. E., 1963, Upper Mesozoic microfloras from south-eastern Australia: Royal Soc. Victoria Proc., new ser. v. 77 , pt. 1 , p. 1-148, pls. I-XXVII.

Döring, Harry, 1966, Sporenstratigraphischer Vergleich zwischen dem Wealden Norddeutschlands und südenglands: Geologie, v. 15, no. 55, p. 102-129, pls. I-VII.

Drugg, W. S., 1967, Palynology of the upper Moreno Formation (Late Cretaceous-Paleocene), Escarpado Canyon, California: Palaeontographica, ser. B, v. 120, nos. 1-4, p. 1-71, pls. 1-9.

Elsik, W. C., 1968a, Palynology of a Paleocene Rockdale lignite, Milam County, Texas-[Part] I, Morophology and taxonomy: Pollen et Spores, v. 10, no. 2, p. 263314, pls. I-XV.

1968b, Palynology of a Paleocene Rockdale lignite, Milam County, Texas-[Part] II, Morphology and taxonomy (end) : Pollen et Spores, v. 10, no. 3, p. 599664 , pls. XVI-XLIV.

Erdtman, Gunnar, 1947, Suggestions for the classification of fossil and recent pollen grains and spores: Svensk Bot. Tidskr., v. 41 , no. 1 , p. 104-114.

- 1948, Did dictyledonous plants exist in early Jurassic times?: Geol Fören. Stockholm Förh., v. 70, pt. 2, no. 453 , p. $265-271$.

Funkhouser, J. W., 1961, Pollen of the genus Aquilapollenites: Micropaleontology, v. 7, no. 2, p. 193-198, pls. 1, 2.

Groot, J. J., and Penny, J. S., 1960, Plant microfossils and age of nonmarine Cretaceous sediments of Maryland and Delaware: Micropaleontology, v. 6, no. 2, p. 225236, pls. 1, 2.

Habib, Daniel, 1969, Middle Cretaceous palynomorphs in a deep-sea core from the Seismic Reflector Horizon A outcrop area: Micropaleontology, v. 15, no. 1, p. 85-101, pls. $1-4$.

Hammen, Thomas van der, 1956, A palynological systematic nomenclature: Bol. Geologico, v. 4, no. $2-3$, p. 63-101, pls. I-XII.

Hammen, Thomas van der, and Wymstra, T. A., 1964, A palynological study on the Tertiary and Upper Cretaceous of British Guiana: Leidse Geol. Meded., v. 30, p. 183-241, pls. I-III.

Hayden, F. V., 1859, Geological sketch of the estuary and fresh water deposits of the Bad lands of the Judith, with some remarks upon the surrounding formations: 
Am. Philos. Soc., Trans., v. 11, new ser., pt. II, art. XII, p. 123-138, 1 map.

- 1871, Preliminary report of the United States Geological Survey of Wyoming and portions of contiguous Territories (being a second annual report of progress): U.S. Geol. and Geog. Survey Territories 4th Ann. Rep., $511 \mathrm{p}$.

Hedlund, R. W., 1966, Palynology of the Red Branch Member of the Woodbine Formation (Cenomanian), Bryan County, Oklahoma: Oklahoma Geol. Survey Bull. 112, 69 p., pls. 1-10.

Hoeken-Klinkenberg, P. M. J., van, 1964, A palynological investigation of some Upper-Cretaceous sediments in Nigeria: Pollen et Spores, v. 6, no. 1, p. 209-231, pls. I-VII.

Hughes, N. F., 1961, Further interpretation of Eucommiidites Erdtman 1948: Palaeontology, v. 4, pt. 2, p. 292 299 , pls. 37,38 .

Ibrahim, Achmed, 1932, Beschreibung von Sporenformen aus Flöz Ägir, in Potonié, Robert, Sporenformen aus den Flözen Ägir und Bismarck des Ruhrgebietes: Neues Jahrb. Mineralogie, Geologie, u. Paläontologie, Beil.Band, Abt. B, v. 67 p. $447-449$, pls. XIV-XVII.

Ibrahim, Ahmet Can, 1933, Sporenformen des Aegirhorizonts des Ruhr-Reviers: Würburg, Buchdruckerei Konrad Triltsch, 46 p., pls. I-VIII.

Jansonius, Jan, 1962, Palynology of Permian and Triassic sediments, Peace River area, western Canada: Palaeontographica, ser. B, v. 110, nos. 1-4, p. 35-98, pls. 11-16.

Jardiné, Serge, and Magloire, Lili, 1965, Palynologie et stratigraphie du Crétacé des bassins du Sénégal et de Côte d'Ivoire, in Colloq Internat. de Micropaléontologie, Dakar 1963, Bur. Recherches Géol. et Minières Mem. 32, p. 187-245, pls. I-XI.

Jersey, N. J. de 1964, Triassic spores and pollen grains from the Bundama Group: Queensland Geol. Survey Pub. 321, 21 p., pls. 1, 2.

Klaus, Wilhelm, 1960, Sporen der Karnischen Stufe der ostalpinen Trias: Geol. Jahrb. Bundesanst.-Wien, v. 5, p. 107-182 pls. 28-38.

Kremp, G. O. W., 1949, Pollenanalytische Untersuchung des Miozänen Braunkohlenlagers von Konin an der Warthe: Palaeontographica, ser. B., v. 90, nos. 1-3, p. 53-93, pls. III-IX.

Kremp, G. O. W., and Gerhard, J. E., 1961, Pollen and spores from the lower Tertiary of North and South Dakota, and some taxonomic problems concerning their designation, in Origin and construction of coal, 3d Conf., Crystal Cliffs, Nova Scotia, 1956: Halifax, p. 257-269, pls. I, II.

Krutzsch, Wilfried, 1957, Sporen-und Pollengruppen aus der Oberkreide und dem Tertiär Mitteleuropas und ihre stratigraphische Verteilung: Zeitsch. Angew. Geologie, v. 3 , no. $11 / 12$, p. $509-548$, pls. I-XVI.

1959a, Mikropaläontologische (sporenpaläontologische) Untersuchungen in der Braunkohle des Geiseltales-[Part] I, Die Sporen und die Sporenartigen sowie ehemals im Geiseltal zu Sporites gestellten Formeinheiten der Sporae dispersae der mitteleozänen Braunkohle des mittleren Geiseltales (Tagebau Neumark-West i.w.S.) unter Berücksichtigung und Revision weiterer Sporenformen aus der bisherigen Literatur: Geologie, v. 8, no. 21/22, pls. I-XLIX.

1959b, Einige neue Formgattungen-und arten von
Sporen und Pollen aus der mitteleuropäischen Oberkreide und dem Tertiär: Palaeontographica, ser. B, v. 105, nos. 5-6, p. 125-157, pls. 31-35.

- 1960, Beitrag zur Sporenpaläontologie der präoberoligozänen kontinentalen und marinen Tertiärablagerungen Brandenburgs: Geol. Gesell. DDR Ber., v. 5, no. 4, p. $290-343$, pls. I-V.

1962, Stratigraphisch bzw. botanisch wichtige neue Sporen- und Pollenformen aus dem deutschen Tertiär: Geologie, v. 11, no. 3, p. 265-307, pls. I-X.

- 1963a, Atlas der mittel- und jungtertiären dispersen Sporen- und Pollen- sowie der Mikroplanktonformen des nördlichen Mitteleuropas-Lieferung II, Die Sporen der Anthocerotaceae und der Lycopodiaceae: Berlin, VEB Deutscher Verlag der Wisserschaften, 141, p., pls. 1-50.

1963b, Atlas der mittel- und jungtertiären dispersen Sporen- und Pollen- sowie der Mikroplanktonformen des nördlichen Mitteleuropas-Lieferung III, Sphagnaceoide und selaginellaceoide Sporenformen: Berlin, VEB Deutscher Verlag der Wissensschaften, 128 p., pls. $1-43$.

1966, Zur kenntnis der präquartären periporaten Pollenformen: Geologie, v. 15, no. 55, p. 16-71, pls. IIX.

1969, Taxonomie syncolp(or) ater und morphologisch benachbarter Pollengattungen und -arten (sporae dispersae) aus der Oberkreide und dem Tertiaer-Teil I, Syncolp(or)ate und syncolp(or) atoide Pollenformen: Pollen et Spores, v. 11, no. 2, p. 397-424, pls. 1, 2.

- 1970, Taxonomie syncolp(or)ater und morphologish benachbarter Pollengattungen und -arten (sporae dispersae) aus der Oberkreide und dem Tertiar-Teil II, Aquilapolles (=Triprojectacites): Pollen et Spores, v. 12 , no. 1 , p. 103-122, pl. 3.

Kuyl, O. S., Muller, J., and Waterbolk, H. Th., 1955, The application of palynology to oil geology with special reference to western Venezuela: Geologie en Mijnbouw, no. 3 , new ser., v. 17 , p. $49-76$, pls. $1-8$.

Lanjouw, Joseph, chm., and others, 1952, International code of botanical nomenclature: Utrecht, Netherlands, Internat. Bur. Plant Taxonomy and Nomenclature, $228 \mathrm{p}$. 1966, International code of botanical nomenclature: Utrecht, Netherlands, Internat. Bur. Plant Taxonomy and Nomenclature, $402 \mathrm{p}$.

Lantz, Josette, 1958, Étude palynologique de quelques échantillons Mésozoiques du Dorset (Grande-Bretagne) : Inst. Français Pétrole Rev. et Annales Combustibles Liquides, v. 13, no. 6, p. 917-942, pls. I-VII.

Leffingwell, H. A., 1971, Palynology of the Lance (Late Cretaceous) and Fort Union (Paleocene) Formations of the Type Lance Area, Wyoming, in Kosanke, R. M., and Cross, A. T., eds., Symposium on Palynology of the Late Cretaceous and Early Tertiary: Geol. Soc. America Spec. Paper 127, p. 1-64, pls. 2-10

Leopold, E. B., and Pakiser, H. M., 1964, A preliminary report on the pollen and spores of the pre-Selma Upper Cretaceous strata of western Alabama: U.S. Geol. Survey Bull. 1160-E, p. 71-95, pls. 3-9.

Leschik, Georg, 1955, Die Keuperflora von Neuewelt bei Base -[Part] II, Die Iso- und Mikrosporen: Schweizer. Paläont. Abh.,-Mem. Suisses Paleont., v. 72, no. 1, p. 1-70, pls. $1-10$.

- 1956, Sporen aus dem Salzton des Zechsteins von 
Neuhof (bei Fulda): Palaeontographica, ser. B, v. 100 nos. 4-6, p. 122-142, pls. 20-22.

Maliavkina, V. A., 1949, Opredelitel' spor i ply'tsy Iura-Mel [Determination of spores and pollen, Jurassic-Cretaceous] : Vses. Neft. Nauchno-Issled. Geol.-Razved. Inst. Trudy, new ser., v. 33, 137 p., 51 pls.

Manum Svein, 1960, On the genus Pityosporites Seward 1914, with a new description of Pityosporites antarcticus Seward: Reprint from Nytt Mag. Botanikk, v. 8, p. 1115, pl. 1 .

__ 1962, Studies in the Tertiary flora of SpitsbergenA palynological investigation: Norsk Polarinst. Skr., no. 125,127 p., pls. I-XX.

Miner, E. L., 1935, Paleobotanical examinations of Cretaceous and Tertiary coals-[Part] I, Cretaceous Coals from Greenland [and Part] II, Cretaceous and Tertiary coals from Montana. Am. Midland Naturalist, v. 16, no. 4, p. 585-625, pls. 18-24.

Newman, K. R., 1965, Upper Cretaceous-Paleocene guide palynomorphs from northwestern Colorado: Colorado Univ. Studies Ser. Earth Sci., no. 2, 21 p., pl. 1.

Nilsson, Tage, 1958, Über das vorkommen eines mesozoischen Sapropelgesteins in Schonen: Lunds Univ. Arsskr., new ser., pt. 2, v. 54, no. 10,111 p., pls. 1-8.

Norris, G., 1967, Spores and pollen from the lower Colorado Group (Albian-? Cenomanian) of central Alberta: Palaeontographica, ser. B, v. 120 , nos. $1-4$, p. $72-115$, pls. $10-18$.

Norton, N. J., and Hall, J. W., 1967, Guide sporomorphae in the Upper Cretaceous-Lower Tertiary of eastern Montana (U.S.A.) : Rev. Palaeobotany and Palynology, v. 2, nos. 1-4, p. 99-110, pl. I.

- 1969, Palynology of the Upper Cretaceous and Lower Tertiary in the type locality of the Hell Creek Formation, Montana, U.S.A.: Palaeontographica, ser. B, v. 125, nos. 1-3, 64 p., pls. $1-8$.

Oltz, D. F., Jr., 1969, Numerical analyses of palynological data from Cretaceous and Early Tertiary sediments in east central Montana: Palaeontographica, ser. B, v. 128, nos. 3-6, p. $90-166$, pls. 39-42.

Pacltova, Blanka, 1961. On some plant microfossils from fresh-water sediments of the Upper Cretaceous (Senonian) in the South Bohemian Basins, Part I: [Czechoslovakia] Ustřed. Ustav. Geol. Sbornik, v. 26, section paleontology, p. 84-102, pls. I-XXIV.

Pant, D. D., 1954, Suggestion for the classification and nomenclature of fossil spores and pollen grains: Bot. Rev., v. 20, no. 1, p. 33-60.

Pautsch, M. E., 1958, Keuper sporomorphs form Swierczyna, Poland: Micropaleontology, v. 4, no. 3, p. 321-325, pl. 1.

Pflug, H. D., 1953, Zur Entstehung und Entwicklung des Angiospermiden pollens in der Erdgeschichte. Palaeontographica, ser. B, v. 95, nos. 4-6, p. 60-171, pls. 15-25.

Pierce, R. L., 1961, Lower Upper Cretaceous plant microfossils from Minnesota: Minnesota Geol. Survey Bull. 42,86 p., pls. I-III.

Playford, Geoffrey, and Dettmann, M. E., 1965, RhaetoLiassic plant microfossils from the Leigh Creek Coal Measures, South Australia: Senckenbergiana Lethaea, v. 46, p. $127-181$, pls. $12-17$.

Pocock, S. A. J., 1962, Microfloral analysis and age determination of strata at the Jurassic-Cretaceous boundary in the western Canada plains: Palaeontographica, ser. B, v. 111, nos. 1-3, p. 1-95, pls. 1-15.
1964, Pollen and spores of the Chlamydospermidae and Schizaeaceae from Upper Mannville strata of the Saskatoon area of Saskatchewan: Grana Palynologica, v. 5, no. 2, 129-209, pls. 1-7.

1968, Zonalapollenites Pflug 1953 and related genera: Taxon, v. 17, no. 6. p. 639-641.

Pocock, S. J., and Jansonius, Jan, 1961 The pollen genus Classopollis Pflug, 1953: Micropaleontology, v. 7, no. 4, p. $439-449$, pl. 1 .

Potonié, Robert, 1931a, Zur Mikroskopie der BraunkohlenTertiäre Blütenstaubformen: Braunkohle v. 30 , no. 16 , p. 325-333, pls. I, II.

1931b, Pollenformen der miocänen Braunkohle (2. Mitteilung): Sitzungber. Gesell Naturf. Freunde Berlin, (1931), no. 1-3, p. 24-27, pls. 1-2.

1931c Pollenformen aus tertiären Braunkohlen: Jahrb. Preussische Geol. Landesanst. Jahrb., v. 52, p. 1-7.

- 1931d, Zur Mikroskopie der Braunkohlen-[Part] IV, Tertiäre Sporen-und Blütenstaubformen. Braunkohle, v. 30 , no. 27, p. $554-556$.

- 1934, Zur Mikrobotanik der Kohlen und ihrer Verwandten-[Part] II, Zur Mikrobotanik des eocänen Humodils des Geiseltals: Inst. Paläobotanik u. Petrographie Brennsteine Arb., v. 4, p. 25-125, pls. 1-6.

— 1951, Revision stratigraphisch wichtiger Sporomorphen des mitteleuropäischen Tertiärs: Palaeontographica, ser, B, v. 91, nos. 5-6, p. 131-151, pls. XX-XXI. - 1956, Synopsis der Gattungen der Sporae dispersae --Teil I, Sporites: Beihefte Geol. Jahrb., Hannover, no. 23, 103 p., pls. $1-11$.

—_ 1958, Synopsis der Gattungen der Sporae dispersae -Teil II, Sporites (Nachträge), Saccites, Aletes, Praecolpates, Polyplicates, Monocolpates: Beihefte Geol. Jahrb., Hannover, no. 31, 114 p., pls. 1-11.

- 1960, Synopsis der Gattungen der Sporae dispersae -Teil III, Nachträge Sporites, Fortsetzung Pollentites mit Generalregister zu Teil I-III : Beihefte Geol. Jahrb., Hannover no. 39,189 , p., pls. 1-9.

1966, Synopsis der Gattungen der sporae dispersae -Teil IV, Nachträge zu allen Gruppen (Turmae) : Beihefte Geol. Jahrb., Hannover, no. 72, 244 p., pls. 1-15.

1970, Synopsis der Gattungen der sporae dispersaeTeil V, Nachträge $\mathrm{zu}$ allen Gruppen (Turmae) : Beihefte Geol. Jahrb., Hannover, no. 87, 222 p., pls. 1-24.

Potonié, Robert, and Gelletich, Johann, 1953, Über Pteridophyten-Sporen einer eocänen Braunkohle aus Dorog in Ungarn: Sitzungber. Gesell. Naturf. Freunde Berlin (1932), v. 33, p. 517-528, pls. 1, 2.

Potonié, Robert, and Klaus, Wilhelm, 1954, Einige Sporengattungen des alpinen Salzgebirges: Geol. Jahrb., v. 68 , p. $517-546$, pl. 10.

Potonié, Robert, and Kremp, G. O. W., 1954 Die Gattungen der paläozoischen Sporae dispersae und ihre Statigraphie: Geol. Jahrb., v. 69, p. 111-194, pls. 4-20.

- 1956, Die Sporae dispersae des Ruhrkarbons, ihre Morphographie und Stratigraphie mit ausblicken auf arten anderer Gebiete und Zeitabschnitte, Teil II : Palaeontographica, ser. B, v. 99, nos. 4-6, p. 85-191, pls. 17-22.

Potonié, Robert, Thomson, P. W., and Thiergart, Friedrich, 1950, Zur Geologie der rheinischen Braunkohle-_[Part] 1, Zur Nomenklatur und Klassifikation der neogenen 
Sporomorphae (Pollen und Sporen): Geol. Jahrb., v. 65 , p. 35-69, 141-144, pls. A-C.

Potonié, Robert, and Venitz, Herbert, 1934, Zur Mikrobotanik der Kohlen und ihrer Verwandten-[Part] I, Zur Mikrobotanik des miocänen Humodils der niederrheinischen Bucht: Inst. Palaobotanik u. Petrographie Brennsteine Arb., v. 5, p. 5-54, pls. 1-4.

Raatz, G. V., 1937, Mikrobotanisch-stratigraphische Untersuchung der Braunkohle des muskauer Bogens: Preussische Geol. Landesans Abh., new ser., no. 183, p. 5-48, pl. 1.

Radforth, N. W., and Rouse, G. E., 1954, The classification of recently discovered Cretaceous plant microfossils of potential importance to the stratigraphy of western Canadian coals [Alberta]: Canadian Jour. Botany, v. 32 , no. 1 , p. $187-201$, pl. I.

Reissinger, Adolph, 1939, Die "Pollenanalyse" ausgedehnt auf alle Sedimentgesteine der geologischen Vergangenheit: Paleontographica, ser. B, v. 84, p. 1-20.

- 1950, Die "Pollenanalyse" ausgedehnt auf alle Sedimentgesteine der geologischen vergangenheit, zweiter Teil. Palaeontographica, ser, B, v. 90, nos. 4-6, p. 99126, pls. XI-XIX.

Ross, Nils-Erik, 1949, Investigations of the Senonian of the Kristianstad District, S. Sweden-[Part], I, On a Cretaceous pollen and spore bearing clay deposit of Scania: Uppsala Univ. Geol. Inst. Bull., v. 34, p. 2543 , pls. I-III.

Rouse, G. E., 1957, The application of a new nomenclatural approach to Upper Cretaceous plant microfossils from western Canada: Canadian Jour. Botany, v. 35, no. 3, p. $349-375$, pls. I-III.

- 1959, Plant microfossils from Kootenay coal-measures strata of British Columbia: Micropaleontology, v. 5, no. 3 , p. 303-324, pls. $1,2$.

1962, Plant microfossils from the Burrard Formation of western British Columbia: Micropaleontology, v. 8 , no. 2 , p. $187-218$, pls. $1-5$.

Samoilovitch, S. R., 1965, Pyl'tsa novykh vidov verkhnemelovykh pokrytosemennykh rastenii Iakutii [Pollen of new species of Upper Cretaceous angiosperm plants of Yakutia], in Samoilvitch, S. R., ed., Paleofitologicheskii sbornik: Vses. Neft. Nauchno-Issled. Geol.-Razved. Inst. Trudy, v. 239 , p. $121-141,402-411$, pls. I-V.

Samoilovitch, S. R., and others, 1961, Ply'tsa i spory zapadnoi Sibiri, Iura-Paleotsen [Pollen and spores of western Siberia, Jurassic-Paleocene]: Vses. Neft. NauchnoIssled. Geol.-Razved. Inst. Trudy, v. 177, 352 p., pls. 1-84 and I-LXV.

Sato, Seiji, 1961, Pollen analysis of carbonaceous matter from the Hakobuchi group in the Enbetsu district, Nor:hern Hokkaido, Japan-[Part] I, Palynological study on Cretaceous sediments: Hokkaido Univ. Fac. Sci. Jour., ser. 4, Geology and Mineralogy, v. 11, no. 1, p. 7793 , pls. I-II.

Schopf, J. M., Wilson, L. R., and Bentall, Ray, 1944, An annotated synopsis of Paleozoic fossil spores and the definition of generic groups: Illinois Geol. Survey Rept. Inv. 91, 73p., pls. 1-3.

Seward, A. C., 1914, Antarctic fossil plants: British Mus. (Nat. History), Terra Nova Exped. 1910 Rept., Geology, v. 1, p. $1-49$, pls. $1-8$.

Simones cs, P.; and Kedves, M., 1961, Paleobotanical examinations on manganese series in Urkut (Hungary, Trans- danubia): Acta Mineralogica Petrographica, v. 14, p. 27-57, pls. I-X.

Singh, Chaitanya, 1964, Microflora of the Lower Cretaceous Mannville Group, east-central Alberta: Research Council Alberta Bull. 15, 239 p., pls. 1-29.

Skarby, Annie, 1964, Revision of Gleicheniidites senonicus Ross: Stockholm Contr. Geology, v. 11, p. 59-77, pls. I-III.

Skuratenko, A. V., 1966, Turonskie sporovo-ply'tsevye kompleksy nekotorykh raionov zapadnoi Sibiri [Turonian spore and pollen assemblages of some regions of west Siberia], in 2d International Conference on Palynology, Utrecht, 1966: Akad. Nauk SSSR Palinologiia Sibiri, p. $84-89$, pls. I, II.

Srivastava, S. K., 1966, Upper Cretaceous microflora (Maestrichtian) from Scollard, Alberta, Canada: Pollen et Spores, v. 8, no. 3, p. 497-552, pls. I-XI.

1968a, Reticulate species of Aquilapollenites and emendation of genus Mancicorpus Mtchedlishvili: Pollen et Spores, v. 10 , no. 3 , p. $665-699$, pls. I-VII.

1968b, Ephedralean pollen from the Upper Cretaceous Edmonton Formation of Alberta (Canada) and their paleoecological significance. Canadian Jour. Earth Sci., v. 5, no. 2, p. 211-221, pl. I.

1969a, New spinulose Aquilapollenites spp. from the Edmonton Formation (Maestrichtian), Alberta, Canada: Canadian Jour. Earth Sci., v. 6, no. 1, p. 133-144, pls. I-VIII.

1969b, Assorted angiosperm pollen from the Edmonton Formation (Maestrichtian), Alberta, Canada: Canadian Jour. Botany, v. 47 , no. 6, p. 975-989, pls. IIII.

1969c, Mtchedlishvilia canadiana gen. et sp. nov. from the Edmonton Formation (Maestrichtian), Alberta, Canada: Pollen et Spores, v. 11, no. 3, p. 615-618, pl. I. - 1969d, Some angiosperm pollen from the Edmonton Formation (Maestrichtian), Alberta, Canada, J. Sen Memorial Volume in: J. Sen Memorial Comm., Bot. Soc. Bengal, p. 47-67, pls. 1, 2.

Srivastava, S. K., and Rouse, G. E., 1970, Systematic revision of Aquilapollenites Rouse 1957: Canadian Jour. Botany, v. 48, no. 9, p. 1591-1601, pls. I, II.

Stanley, E. A., 1961, The fossil pollen Genus Aquilapollenites: Pollen et Spores, v. 3, no. 2, p. 329-352, pls. 1-8. (Includes French and German summ.)

- 1965, Upper Cretaceous and Paleocene plant microfossils and Paleocene dinoflagellates and hystrichosphaerids from northwestern South Dakota: Bull. Am. Paleontology, v. 49 , no. 222 , p. $175-384$, pls. $19-49$.

Stanton, T. W., and Hatcher, J. B., 1905, Geology and paleontology of the Judith River Beds: U.S. Geol. Survey Bull. 257, $174 \mathrm{p}$.

Stover, L. E., 1962, Taurocusporites, a new trilete spore genus from the Lower Cretaceous of Maryland: Micropaleontology, v. 8 , no. 1 , p. 55-59, pl. 1.

Stover, L. E., Elsik, W. C., and Fairchild, W. W., 1966, New genera and species of early Tertiary palynomorphs from Gulf Coast: Kansas Univ. Paleont. Contr., Paper 5, 11 p., pls. 1-5.

Takahashi, Kiyoshi, 1964, Sporen und Pollen der oberkretazeischen Hakobuchi-Schichtengruppe, Hokkaido: Kyushu Univ. Fac. Sci. Mem., ser. D, Geology, v. 14, no. $3,159-271$, pls. 23-44.

Thiergart, Friedrich, 1937, Die Pollenflora der Nieder- 
lausitzer Braunkohle, besonders im Profil der Grube Marga bei Senftenberg: Preussische Geol. Landesanst. Jahrb. 1937 , v. 58 , p. 282-351, pls. 22-30. [1938]

1940, Die Mikropaläontologie als Pollenanalyse im Dienst der Braunkohlenforschung: Brennstoff-Geologie Schr., Stuttgart, no. 13, p. 1-82, pls. I-XIV.

Thomson P. W., and Pflug, Hans, 1953, Pollen und Sporen des mitteleuropäischen Tertiärs: Palaeontographica, ser. B, v. 94, nos. 1-4, p. 1-138, pls. 1-15.

Traverse, Alfred, 1955, Pollen analysis of the Brandon lignite of Vermont: U.S. Bur. Mines Rept. Inv. 5151, $107 \mathrm{p}$.

Tschudy, B. D., 1969, Species of Aquilapollenites and Fibulapollis from two Upper Cretaceous localities in Alaska: U.S. Geol. Survey Prof. Paper 643-A, 17 p., pls. 1-16.

- 1971, Two new fossil pollen genera from upper Campanian (Creteaceous) rocks of Montana, in Geological Survey research 1971: U.S. Geol. Survey Prof. Paper 750-B, p. B53-B61, figs. 1-4.

Tschudy, B. D., and Leopold, E. B., 1971 Aquilapollenites (Rouse) Funkhouser-selected Rocky Mountain taxa and their stratigraphic ranges, in Kosanke, R. M., and Cross, A. T., eds., Symposium on palynology of the Late Cretaceous and Early Tertiary; Geol. Soc. America Spec.
Paper 127, p. 113-167, pls. 1-4.

Tschudy, R. H., 1970, Two new pollen genera (Late Cretaceous and Paleocene) with possible affinity to the Illiciaceae: U.S. Geol. Survey Prof. Paper 643-F, 13 p., pls. 1-9.

Weyland, Hermann, and Krieger, Wilhelm, 1953, Die Sporen und Pollen der Aachener Kreide und ihre Bedeutung für die charakterisierung des Mittleren Senons: Palaeontographica, ser. B, v. 95, nos. 1-3, p. 6-29, pls. 1-5.

Wilson, L. R., and Coe, E. A., 1940, Descriptions of some unassigned plant microfossils from the Des Moines Series of Iowa: Am. Midland Naturalist, v. 23, no. 1, p. 182-186, pl. 1.

Wodehouse, R. P., 1933, Tertiary pollen-[Part] II, The oil shales of the Eocene Green River formation: Torrey Bot. Club Bull., v. 60, no. 7, p. 479-524.

Wolf, Monika, 1964, Sporomorphen aus dem bayerischen Flysch: Fortschr. Geologie Rheinland u. Westfalen, v. 12, p. 113-116, pl. 1.

Wolff, Herbert, 1934, [Part] II, Mikrofossilien des pliocänen Humodils der Grube Freigericht bei Dettingen a. M. und Vergleich mit älteren Schichten des Tertiärs sowie posttertiären Ablagerungen: Preussische Geol. Landesanst. Abh., v. 5, p. 55-86, pl. 5. 


\section{INDEX}

[Italic page numbers indicate major references and descriptions]

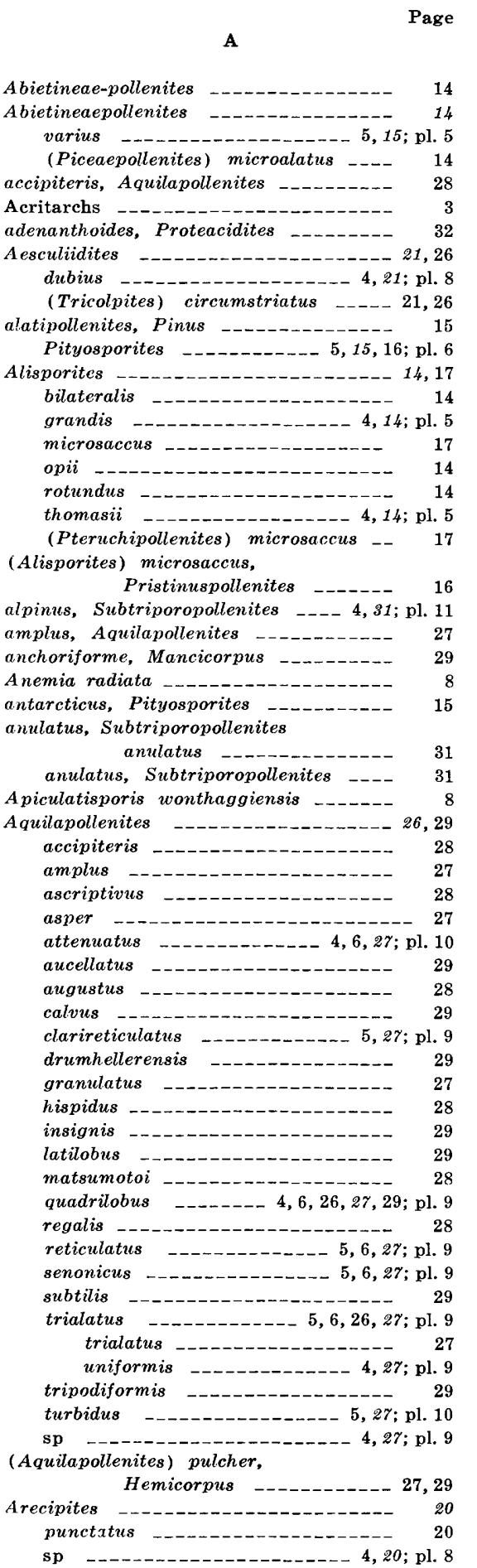

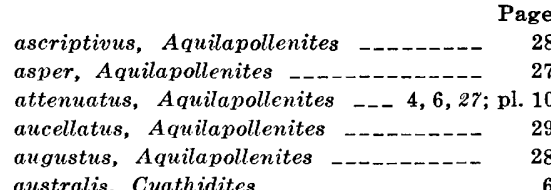

\section{B}

bacata, Cranwellia _-_._._._. 4, 6, 26; pl. 9 (Bacubivesiculites) inchoatus, Pristinuspollenites _-_-- 16; p1. 7

Bzculatisporites _._.

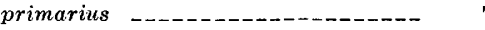
sp barbatus, Seductisporites --_ 5, 6, 12, 13; pl. 4 biformis, Podocarpidites -_. 16 bilateralis, Alisporites --_-_-_-_-_-_ 14

Bisaccates -_..-_-_-_-_-_-_-_-_-_ 4,14 blanensis, Zlivisporis - 13

\section{C}

callosus, Umbosporites

lvus, Aquilapollenites Mancicorpus _-_Camarozonosporites _-_-_-_-_-_-_--- 11 (Rotaspora) cretaceus --_._----- 11 spp canadensis, Grewipollenites _-_._-_ 21, 22, 26 canadianus, Mancicorpus _-_..-_-_-_ 29 Mancicorpus (Mtchedlishvilia) ---- 29 canaliculatus, Microfoveolatosporis_ 4, 11; pl. 3 catteralli, Sindorapollis -_-_-_--_-_--- 30 Sindorapollis (Loranthacites) ---- 29 Caytoniales-Pollenites --Caytonipollenites _-_-_-_-_-_-_-_-_-- 18

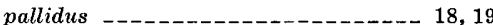
Cedripites - - cretaceus -_-_-_-_-_-_-- 5, 15; pl. 5 eocenicus -------------_------ 15 parvus -_-_-_-_-_-_-_ 4, 15 ; pl. 5 chinleana, Equisetosporites ----_---- 20 chlonovae, Taurocusporites --------- 9 Trisolissporites _...___ 5, 6, 10; pl. 2 Cicatricosi-sporites --_-_-_-_-_--- 8 Cicatricosisporites -_-_-_-_-_-_--_-_-- 8

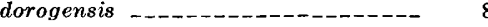
radiatus --_-_-__..-- 4, 8; pl. 1 stoveri _-_-_-_-_-_-_-_--- 5,8 ; pl. 1 sp _Circularesporites -circulus, Polycingulatisporites _-..-...- 8 circumstriatus, Aesculiidites

(Tricolpites) _-_._- 21, 26

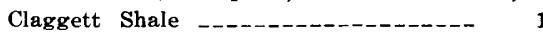
clarireticulatus, Aquilapollenites_-- 5, 27; pl. 9

Integricorpus _._-_-_-_-_-_ 27 classoides, Classopollis ---------- 20 Classopollis

classoides - spp _-_._Clavabivesiculites inchoatus _....... pl. 7
(Clavabivesiculites) pannosus, Pristinuspollenites _---- 17; pl. 7 (Clavabivesiculites inchoatus) crassus, Pristinuspollenites -------- pl. 7 chlonovae, Trisolissporites

(Taurocusporites) -_....- 9 complexus, Liliacidites -------- 4, 6, 20; pl. 8 Schizosporis -_- 20 Conosmundasporites _-.-_-_-_-_.-. 7 constrictus, Pityosporites _-_-_._- 5, 15; pl. 5 convolutus, Rugubivesiculites ------- 18 Cornaccoipollenites _-_-_-_-_-_---- 24 costatus, Triatriopollenites _-_._- 5, 31; pl. 11 Cranwellia _-_______-__-_ 5, 26 ; pl. 9 bacata --_-_-_-_ 4, 6,26 ; pl. 9 rumseyensis -_-_-_-_-_- 5, 6, 26; pl. 9 (Elytranthe) striata --.....--_-_- 26 crassus, Pristinuspollenites $\begin{array}{lr}\text { (Clavabivesiculites } & \\ \text { inchoatus) - } & \\ & \end{array}$

\begin{tabular}{rr} 
Triprojectus - & 29 \\
\hline
\end{tabular} crateris, Ischyosporites - Camarozonosporites (Rotaspora) Cedripites Cupanieidites -_-_- 30 major sp - Cyathidites --_-_-_-_- 6 australis -_minor _-_-_-_-_ 4, 6 ; pl. 1 sp -

Dacrydium transiens _-_-_-_-_-_-_ 17

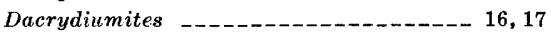
Deltoidospora hallii _..._. 6

$\mathrm{sp}$ Depository of types and other illustrated specimens ----- 3

Dicotetradites granulatus _._._._. 33 Dinoflagellates _-_-_-_-_. 2 Disaccites grandis (Podocarpidites) -..-- 16 dispositus, Triprojectus _-_-_-_-_-_ $\quad 27$ dorogensis, Cicatricosisporites -.--- 8 Droseridites _._. spinulosus _-_.___-____- 5,33; pl. 11 (Tetradites (Droseridites)) spinosa_ 33 (Droseridites), Tetradites _-_-_._- 33 drumhellerensis, Aquilapollenites _-__- 29 dubius, Aesculiidites _..._._._. 4, 21; pl. 8 Striopollenites _-_-_-_-_-_-_-_ 21 dulhuntyi, Dulhuntyispora _-_-____- 9; pl. 2 Dulhuntyispora _.._- 3, 9 dulhuntyi _-_._-_-_-_-_- 9 (Dulhuntyispora minuta) minutus, Trisolissporites _-_._-_ 9

Duplopollis -_-_Dyadites --_-_- 32 Dyadonapites _-_-_-_- 32 reticulatus _-_._-_- 4, 5, 6, 32; pl. 11 Dyads 


\section{Page}

$\mathbf{E}$

ellipticus, Podocarpidites

elongatus, Pinuspollenites - 15

Pityosporites _. Pityosporites elongatus _._-_._. 5 elongatus elongatus, Pityosporites --- 5 grandis, Pityosporites _-___- 5, 15; pl. 6 Elytranthe (Elytranthe) striata, Cranwellia --.- 26 eminens, Seductisporites _-__- 5,6,12; pl. 4 endannulatus, Montanapollis _-- 4, 6, 31 ; pl. 11 cocenicus, Cedripites _._-_-_._-_._ 15 Equisetosporites _._._-_._- 20 chinleana _. spp _-_-_-_-_-_-_-_-_- 4, 20; pl. 8 Erdtmanipollis _._-_._._. pachysandroides _._._. 4,$32 ; \mathrm{pl} .11$

Ericaceoipollenites _-_-_-_-_-_-_-_-_ 33 rallus

Ericipites

crugatus, Tricolpites _-_-_-_-_-_- 25

Eucommiidites

troedssonii

$\mathbf{F}$

Fasciatisporites --_--_-_-_- 10

Fibulapollis -- - 26 scabratus _(Triporina) mirificus _-_---_--- 26 foraminis, Foraminisporis _-_..-Foraminisporis

foraminis -...- 8 wonthaggiensis

G

gemmiferus, Seductisporites - 5,6,11, 13; pl. 3

Ghoshispora _-_._-_._-_.............. 8 scollardiana - sp _-

Gleicheniidites _..._- 10

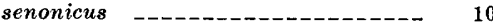
spp _... Granabivesiculites inchoatus _...- 17; pl. 7 (Granabivesiculites) inchoatus, Pristinuspollenites _-__- 17; pl. 7 grandis, Alisporites _-_-_-_-_.- 4, 14; pl. 5 Disaccites -.-_- 14

Pityosporites elongatus --

granisaccus, Pristinuspollenites (Parvisaccites) granospeciosus, Rouseisporites _._-_._- 12 granulatus, Aquilapollenites _-_.-- 27 Dicotetradites _..._. 33 Sindorapollis __._._._- 5,6,30; pl. 10 Grewipollenites -_-_-_-_-_._- 21 canadensis _..._-_-_-_-_- 21, 22, 26 radiatus _......._. $5,6,21 ; \mathrm{pl} .8$ Guninera microreticulata _.......- 23

\section{$\mathrm{H}$}

hallii, Deltoidospora _-_-_-_- 6 Hamulatisporis --_-_-_-_-_-_-- 11 Hemicorpus _......._. 27, 29 (Aquilapollenites) pulcher _-..--- 27, 29 hians, Tricolpites _-__-_ 3, 4, 7, 24; pl. 8 Tricolpopollenites _..._.....- 24 hiatipites, Taxodium _..._-___- 19 hiatus, Inaperturopollenites Pollenites Taxodiaceaepollenites _._._._ 4, 19; pl. 8 (Pollenites) -

hiatus, Taxodiaceae-Poll. hiatus, Taxodiaceae-Poll.

hiatus, Taxodiaceae-pollenites _....--

hiatus, Taxodieaepollenites _-_.------

Taxodieae-Poll. _.__________ 19, 20

hiatus, Taxodieae-pollenites _-_._._-_ 20

Taxodioipoll. _-_____._- 19

Taxodoidites _._- 19

Thuja _-_-_ 19

hiatus paleocaenicus, Pollenites _--_-- 19

hispidus, Aquilapollenites -

igniculus, Sporonites

Tsugaepollenites (Sporonites)

Zonalapollenites

(Sporonites)

Inaperturates

Inaperturopollenites _._._._._._-_ 19, 20

hiatus

Inaperturotetradites _._.

lacunosus _._-_._-_-_._-_-_- 32

scabratus _._._-____ 5, s2, 33; pl. 11

inchoatus, Clavabivesiculties ______._ pl. 7

Granabivesiculites _-_-_-_-_-- 17; pl. 7 Pristinuspollenites

(Bacubivesiculites) _-_- 16; pl. 7 (Granabivesiculites) _-_-- 17; pl. 7

Indusiisporites

insignis, Aquilapollenites

Integricorpus clarireticulatus _-_.--_

interangulus, Tricolpites

Ischyosporites

crateris

punctatus

J

Judith River Formation _-_._-_.-- 1, 6 Juniperus

\section{$\mathbf{K}$}

kaitangataensis, Liliacidites rempii, Pulcheripollenites __.._-_ 4, 22; pl. 8 Ulmoideipites - 31

Kuylisporites _._. 8 waterbolki _..._-_._- 8 spp

\section{$\mathbf{L}$}

lacunosus, Inaperturotetradites _-_-_ $\quad 32$

Laevigato-sporites _... 11

Laevigatosporites vulgaris spp _._._.

laevigatus, Rouseisporites _._-_-_-_ 13

latilobus, Aquilapollenites -

Leptolepidites _...- 7 major _..._._._._._. 4, 7 ; pl. 1 verrucatus levitas, Tricolpopollenites liblarensis, Tricolpopollenites _._._. 23 Libocedrus _-_-_-_-_-_-_- 19 ligneolus, Ovoidites _Pollenites _Sporites Liliacidites _-_-_-_-_-_-_-_-_-_-_-- 20 complexus _-_._-_._-_ 4, 6, 20; pl. 8 kaitangataensis _..._. morrinensis _._variegatus _._._. spp _-_._-

Liquidambarpollenites _._._-_._-__-_ 32

Liquidambar-pollenites _...... 32 Loranthacites _._- 29
(Loranthacites) catteralli,

pilatus, Sindorapollis _-__-_-_- 29

Lycopodium novomexicanum

Lycopodiumsporites novomexicanum --- 12

major, Cupanieidites _Leptolepidites _.

Mancicorpus _._._._. 26, 29 anchoriforme _._. 29 calvus canadianus _._._._._._._._. 29 senonicum _._._._._-_._- 27 tripodiformis -_-_-_-_-- 5, 29; pl. 10 (Mtchedlishvilla) canadianus _..._ 29

matsumotoi, Aquilapollenites _-_._._. 28

maximus, Podocarpidites _-_-_-_-- 16

microalatus, Abietineaepollenites

(Piceaepollenites) -

Microfoveolatosporis _._- 11 canaliculatus _. pseudodentatus _..._._. 11

microreticulata, Gunnera _..-_-_-_ 23

microreticulatus, Pristinuspollenites (Phyllocladidites) _._...-.- 17

Retitricolpites

Tricolpites

Alisporites (Pteruchipollenites)

Pristinuspollenites _.__- $5,6,17$; pl. 7

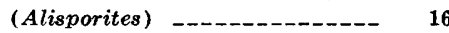
(Pteruchipollenites) _...-.-.- 16

Pteruchipollenites _.________ 17

minimus, Rugubivesiculites _.....-. 18 minor, Cyathidites _._._. 4,$6 ; \mathrm{pl} .1$ Eucommiidites minutus, Trisolissporites _-___-_- 10 Trisolissporites (Dulhuntyispora minuta)

mirificus, Fibulapollis (Triporina) --- 26 Miscellany Monoletes _._._-_._-_._- 11

Monosulcates _. Montanapollis _. endannulatus _..._._._- 4,6,31; pl. 11 montanensis, Siberiapollis _.. 5, 6, $31 ; \mathrm{pl} .11$ Trisolissporites __.____ $5,6,8,9 ; \mathrm{pl} .2$ morrinensis, Liliacidites Mtchedlishvilia (Mtchedlishvilia) canadianus, Mancicorpus _-_-_-_-_- 29 multesimus, Podocarpidites _-_._- 5, 16; pl. 7 Podocarpus _._. 16

\section{$\mathbf{N}$}

narcissus, Pulcheripollenites novomexicanum, Lycopodium Lycopodiumsporites

\section{$\mathbf{0}$}

opii, Alisporites - 14 ornatus, Podocarpidites ___ 5,16 ; pl. 7 Osmundacidites wellmanii -..-_- 8 sp Ovoidites -_ligneolus

pachysandroides, Erdtmanipollis_- 4,32; pl. 11 paleocaenicus, Pollenites hiatus _._._. 19 pallidus, Caytonipollenites _-_._- 18, 19 Pityopollenites -_-_-_-_-_-_-- 18 Pityosporites _Vitreisporites _-_- 
$\begin{array}{rr}\text { pannosus, Pristinuspollenties } & \text { Pag } \\ \text { (Clavabivesiculites) } & \ldots-17 ; \mathrm{pl} .7\end{array}$

Parcisporites _-_-_-_-_-_- 17

parmularius, Tricolpopollenites _.. 24

Tricolpopollenites (Pollenites) _.-- 24

Parviprojectus reticulatus _......- 27

(Parvisaccites) granisaccus, Pristinuspollenites _.._._. 17

parvus, Cedripites _._. Tricolpites _._. 24

Periporopollenites _._. (Pollenites) stigmosus _...- 32 sp

Peroaletes - 11

Phaseolites _..-_._-_-_-_-_-_-_-_- 11

Phyllocladidites - 17

(Phyllocladidites) microreticulatus, Pristinuspollenites _...-.. 17

(Piceaepollenites) microalatus, Abietineaepollenites _.....- 14

pilatus, Sindorapollis 30 Sindorapollis (Loranthacites)

Pinus alatipollenites _-_._-_._- 15 ruginosa 18

Pinuspollenites _-_-_-_-_-_- 15 elongatus _...- 15

Pityopollenites _...... 18 pallidus _-_._- 18

Pityosporites alatipollenites _._._._._. $5,15,16$; pl. 6 antarcticus _.. 15 constrictus _._-_-___-_ 5,$15 ; \mathrm{pl} .5$ elongatus _._._._._._. 15, 16; pl. 6 elongatus _grandis _..._. grandis -_pallidus --_-_- 18

Podocarpidites -- 16

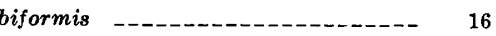
ellipticus -...- 16 maximus _... 16 multesimus ornatus _-_. 5,$16 ; \mathrm{pl} .7$

(Podocarpidites), Disaccites -

Podocarpus multesimus __________-_ 16

Poll. hiatus paleocaenicus _-_-___-_ 19

Pollen-spore zones -

Pollenites - 20

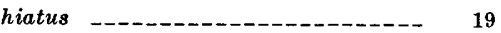
paleocaenicus _.._-_._- 19

ligneolus -21

(Pollenites) hiatus,

Taxodiaceaepollenites _-__ 19, 20

parmularius, Tricolpopollenites _- 24

stigmosus, Periporopollenites _... 32

Polycingulatisporites

circulus _-

spp _...

Polycolpates --

polyformosus, Sequoiapollenites _.... 20

Polypodiaceae-sporites

Polypodium-sporites _to 11

Polyporates _-

primarius, Baculatisporites _-__.._ 7

Pristinuspollenites _-_-_-_-_-_-_- 16 microsaccus __.______- 5, 6, 17; pl. 7 sulcatus _._._._._._._. 17, 18 (Alisporites) microsaccus _-_- 16 (Bacubivesiculites) inchoatus _-- 16; pl. 7 (Clavabivesiculites) pannosus _- 17; pl. 7 (Clavabivesiculites inchoatus) crassus _-_.-_ 7 (Granabivesiculites) inchoatus_-- 17; pl. 7 (Granabivesiculites inchoatus) sulcatus -_(Parvisaccites) granisaccus - 17 (Phyllocladidites) microreticulatus_ 17 (Pteruchipollenites) microsaccus _- 16
Procedure of study

Processing of samples and photography prolata, Tricolporites

Proteacidites

adenanthoides -.. 32

spp

pseudodentatus, Microfoveolatosporis _- 11

Pteruchipollenites microsaccus _-_.- 17

thomasii _._-_._-_._- 14

(Pteruchipollenites) microsaccus, Alisporites _-_._._... 17 microsaccus, Pristinuspollenites --- 16 pulcher, Hemicorpus (Aquilapollenites) 27, 29 Pulcheripollenites _- 22 krempii _... 4, 22; pl. 8 narcissus punctatus, Arecipites Ischyosporites _._._._. 5,$8 ; \mathrm{pl} .1$

quadrilobus, Aquilapollenites __- 4, 6, 26,27, 29; pl. 9

radiata, Anemia - 8 radiatus, Cicatricosisporites _._. 4, 8 ; pl. 1 Grewipollenites _._._._._ 5, 6, 21; pl. 8 Rouseisporites Stenozonotriletes _________-_ 9,10 Trisolissporites _-_._-_._. 10 (Stenozonotriletes) _-_-_-_- 9 (Taurocusporites) _-..-_-_-_ 9 rallus, Ericaceoipollenites --_---_-- 33 regalis, Aquilapollenties _._._..... 28 reticulata, Tricolpites - 23 reticulatus, Aquilapollenites Cyadonapites _._.__ 4,5, 6, 32; pl. 11

Rouseisporites Tricolpites _-_._- 3, 4, 7, 22, 23; pl. 8 Retimonocolpites Retitricolpites microreticulatus _-_._-_ 23 retriculatus, Parviprojectus ___._-_ 27 rhomboides, Tricolporites _(Rotaspora) cretaceus,

Camarozonosporites _-..-. 11

rotundus, Alisporites

Rouseisporites _-_._-_._- 11

granospeciosus _...-. 12

laevigatus _- 13

radiatus _._.

reticulatus - 13

rugatus, Triporopollenites _-_-_-_-_ 31

ruginosa, Pinus _.

Rugubivesiculites _..._._._._- 18

convolutus _________- 18 minimus -_sp rumseyensis, Cranwellia _..._- 5, 6,26; pl. 9 rurensis, Triatriopollenites _._._-_-_ 31

$\mathbf{S}$

Sample localities sarstedtensis, Striatopollis _. scabratus, Fibulapollis _. Inaperturotetradites _-_-- 5, 32,33; pl. 11 Schizosporis complexus --_- 20 scollardiana, Ghoshispora _-_-_--- 8 Seductisporites -_-_-_-_-_-_-_._. 11 barbatus _._._._- 5, 6,12,13; pl. 4 eminens _-_._._._._._. $5,6,12 ; \mathrm{pl} .4$ gemmiferus _..- $5,6,11,13 ; \mathrm{pl} .3$ signifer _segmentatus, Taurocusporites _-..-_ 9 senonicum, Mancicorpus _- 27 senonicus, Aquilapollenites _-_.- 5,6,27; pl. 9 Gleicheniidites _._._. 10
Sequoia-pollenites Page

Sequoiapollenites -_. polyformosus _..- 20 spp Siberiapollis _._. 31 montanensis signatus, Vitreisporites __. signifer, Seductisporites _________- 11, 12 Sindorapollis _-

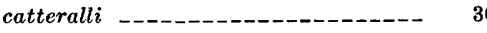
granulatus _._._._. $5,6,30 ; \mathrm{pl} .10$

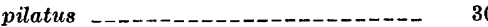
triangulus -.-- 30

(Loranthacites) catteralli _._._... 29 pilatus --_-_- 29

Sphagnites - - -

Sphagnumsporites - 7

spinosa, Droseridites (Tetradites

(Droseridites)) _...... 33

spinulosus, Droseridites

Sporites ligneolus _-_-_-_-_-_-_-- 21

(Sporites) stereoides, Stereisporites --- 7

Sporonites -..-_-_-_-_ 14

igniculus _.

(Sporonites) igniculus, Tsugaepollenites _-..-_-_ 14

(Spronites) igniculus, Zonalapollenites_ stellatus, Stenozonotriletes _-_-_----- 9

Trisolissporites -._-_-_-_-_.-- 10

(Stenozonotriletes) -

(Taurocusporites) _- 9

Stenozonotriletes --_-_- 9

radiatus _-_-_._-_._-_._. 9,10

stellatus _- 9

(Stenozonotriletes) radiatus,

Trisolissporites -_-_-_-_-_ 9

stellatus, Trisolissporites

Stereisporites _-

(Sporites) stereoides _-_._-_._. 7

spp _... stereoides, Stereisporites (Sporites) _._- 7 stigmosus, Periporopollenites

(Pollenites)

stoveri, Cicatricosisporites _._-___ 5, 8; pl. 1

striata, Cranwellia (Elytranthe) ---.- 26

Striatopollis _-_._-___-_ 21, 26 sarstedtensis _....... 26

Striopollenites --_-_- 21

dubius _........... 21

Styx _-_-

subtilis, Aquilapollenites

Subtriporopollenites _-_-_-_-_-_-_ $\$ 1$ alpinus _._._. anulatus anulatus -_-_-_-_-_-_-- 31 sulcatus, Pristinuspollenites - 17, 18 Systematics

$\mathbf{T}$

Taurocusporites _._.

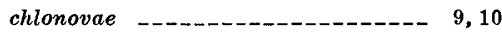
segmentatus

(Taurocusporites) chlonovae, Trisolissporites -...---_-- 9

radiatus, Trisolissporites _..... 9

stellatus, Trisolissporites

Taxodiaceae -.-._. 19, 20

Taxodiaceaepollenites _........... 19

hiatus _._._._._._. 4,$19 ; \mathrm{pl} .8$

(Pollenites) hiatus -_-

Taxodiaceae-Pollenites

Taxodiaceae-Poll. hiatus _-_._-_- 19

Taxodiaceae-Poll. hiatus _._._._. 19

Taxodiaceae-pollenites hiatus _-_-_-- 20

Taxodieae -................

Taxodieacpolenites hiatus _._._... 19

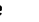

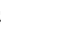

4 
Page

Taxodieae-Poll.

hiatus _.._._.

Taxodieae-pollenites hiatus _....----- 20

Taxodioidites

Taxodioipoll. hiatus _---_-_-_- 19

Taxodium - 19

hiatipites -

Taxodoidites _-_. 19

hiatus _._._-_._- 19

tessellatus, Tricolpopollenites_- $3,4,7,25 ; \mathrm{pl}$. 9

Tetradites (Droseridites) _...-...--_ 33

(Tetradites (Droseridites)) spinosa. Droseridites _-_-_-_-_- 33

Tetrads

thomasii, Alisporites _._._._._. 4,14; pl. 5 Pteurchipollenites -_-_-_-_-_ 14

Thuja _-_._- 19,20

hiatus -_-_-_-_._- 19, 20

transiens, Dacrydium _-...... 17

trialatus, Aquilapollenites___- 5, 6, 26, 27; pl. 9 Aquilapollenites trialatus _._._. 27 trialatus, Aquilapollenites _-..- 27 uniformis, Aquilapollenites _...4,27; pl, 9

triangulus, Sindorapollis _._.

Triatriopollenites _-_-_-_-_- 31 costatus _._.

rurensis -

Tricolpates _- 4,21

Tricolpites - -

erugatus -...- 25

hians _._._._._._._._. $3,4,7,24 ; \mathrm{pl} .8$

interangulus _...-. 23

microreticulatus _.._._.

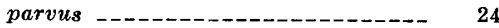

reticulata -..-- 23

reticulatus _...... $3,4,7,22,23 ; \mathrm{pl} .8$

varius _...

spp -

(Tricolpites) circumstriatus,

Aesculiidites _-. 21, 26

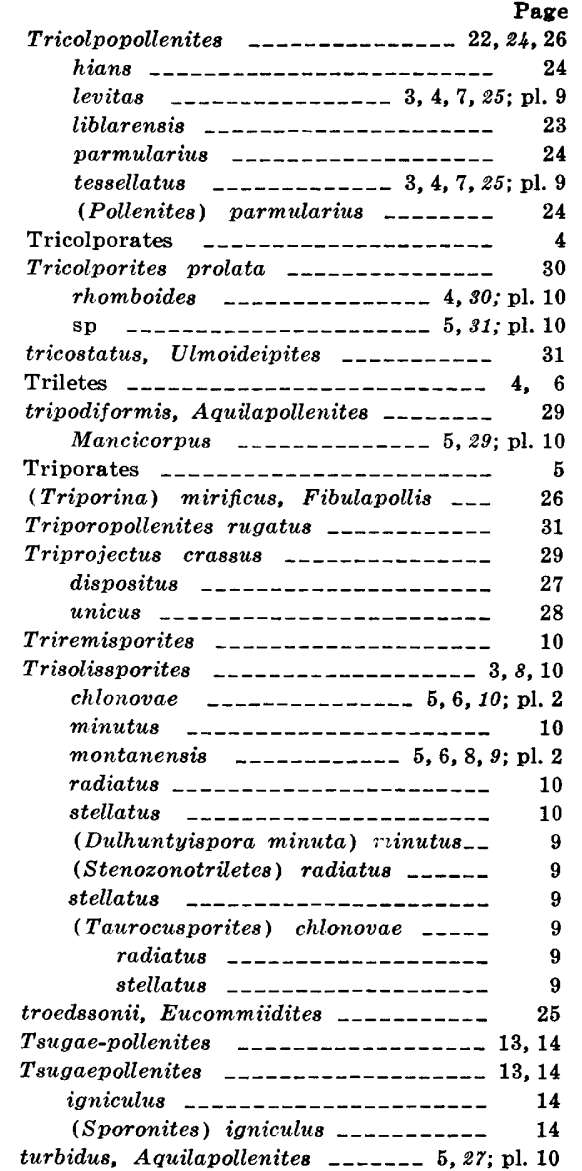

U

Page

Ulmoideipites krempii _-__-_-_-_- 31 tricostatus

Umbosporites callosus

Unclassified bisaccates _-_-_-_._-_-_ 4

Unclassified inaperturates _...... 4

Unclassified monosulcates -

Unclassified triletes --

unicus, Triprojectus _- 28

uniformis, Aquilapollenites trialatus _._.

V

variegatus, Litiacidites varius, Abietineaepollenites

Tricolpites
Trius, Abietineaepollenites

rrucatus, Leptolepidites

Vitreisporites _. 18

pallidus _-

signatus _- 18,19

vulgaris, Laevigatosporites ___._-_. 11

W

, Kyulisporites

wellmani, Osmundacidites _-_-_-_-_- 8

wonthaggiensis, Apiculatisporis _-_-- 8

Foraminisporis _-

$\mathbf{Z}$

Zamia

Zlivisporis

blanensis

Zonalapollenites _-_._-_._. 13

igniculus _._._. 14

(Sporonites) igniculus _..._... 13

sp

Zonates

11 


\section{PLATES 1-11}

Contact photographs of the plates in this report are available, at cost, from U.S. Geological Survey Library, Federal Center, Denver, Colorado 80225. 


\section{PLATE 1}

[All figures $\times 1,000$ except as otherwise indicated]

Figure 1. Cyathidites minor Couper (p. 6).

USGS paleobotany loc. D4067, slide $(3)$ at $78.3 \times 12.0$.

2. Cyathidites sp. (p. 6).

USGS paleobotany loc. D3726-E, slide $(6)$ at $104.8 \times 17.0$.

3. Deltoidospora sp. (p. 6).

USGS paleobotany loc. D4067, slide (10) at $111.1 \times 4.1$.

4,5. Stereisporites spp. (p. 7).

4. USGS paleobotany loc. D3726-D, slide (2) at $99.0 \times 20.2$.

5. USGS paleobotany loc. D3726-D, slide (2) at $109.5 \times 7.9$.

6. Leptolepidites major Couper (p. 7).

USGS paleobotany loc. D3726-E, slide $(6)$ at $88.1 \times 20.3$.

7. Leptolepidites cf. L. major (p. 7).

USGS paleobotany loc. D4067, slide (4) at $96.9 \times 12.2$.

8. Baculatisporites sp. (p. 7).

USGS paleobotany loc. D3725-B, slide (2) at $75.9 \times 13.5$.

9. Osmundacidites sp. (p. 8).

USGS paleobotany loc. D3726-E, slide (2) at $110.8 \times 4.4$.

10, 11. Kuylisporites spp. (p. 8).

10. USGS paleobotany loc. D4067, slide (1) at $94.3 \times 3.4$.

11. USGS paleobotany loc. D4067, slide (4) at $86.6 \times 2.3$.

12. Ischyosporites cf. I. punctatus (p. 8).

USGS paleobotany loc. D3725-E, slide $(2)$ at $100.4 \times 15.6$.

13. Cicatricosisporites stoveri Pocock (p. 8).

USGS paleobotany loc. D3726-E, slide $(5)$ at $105.1 \times 19.9$.

14. Cicatricosisporites sp. (p. 8).

USGS paleobotany loc. D3726-A, slide (5) $93.2 \times 17.1$.

15, 16. Cicatricosisporites radiatus Krutzsch (p. 8).

Two levels. USGS paleobotany loc. D4067, slide (4) at $97.7 \times 10.2$.

17. Ghoshispora sp. (p. 8).

USGS paleobotany loc. D4067, slide $(11)$ at $92.3 \times 18.0 .(\times 500)$. 

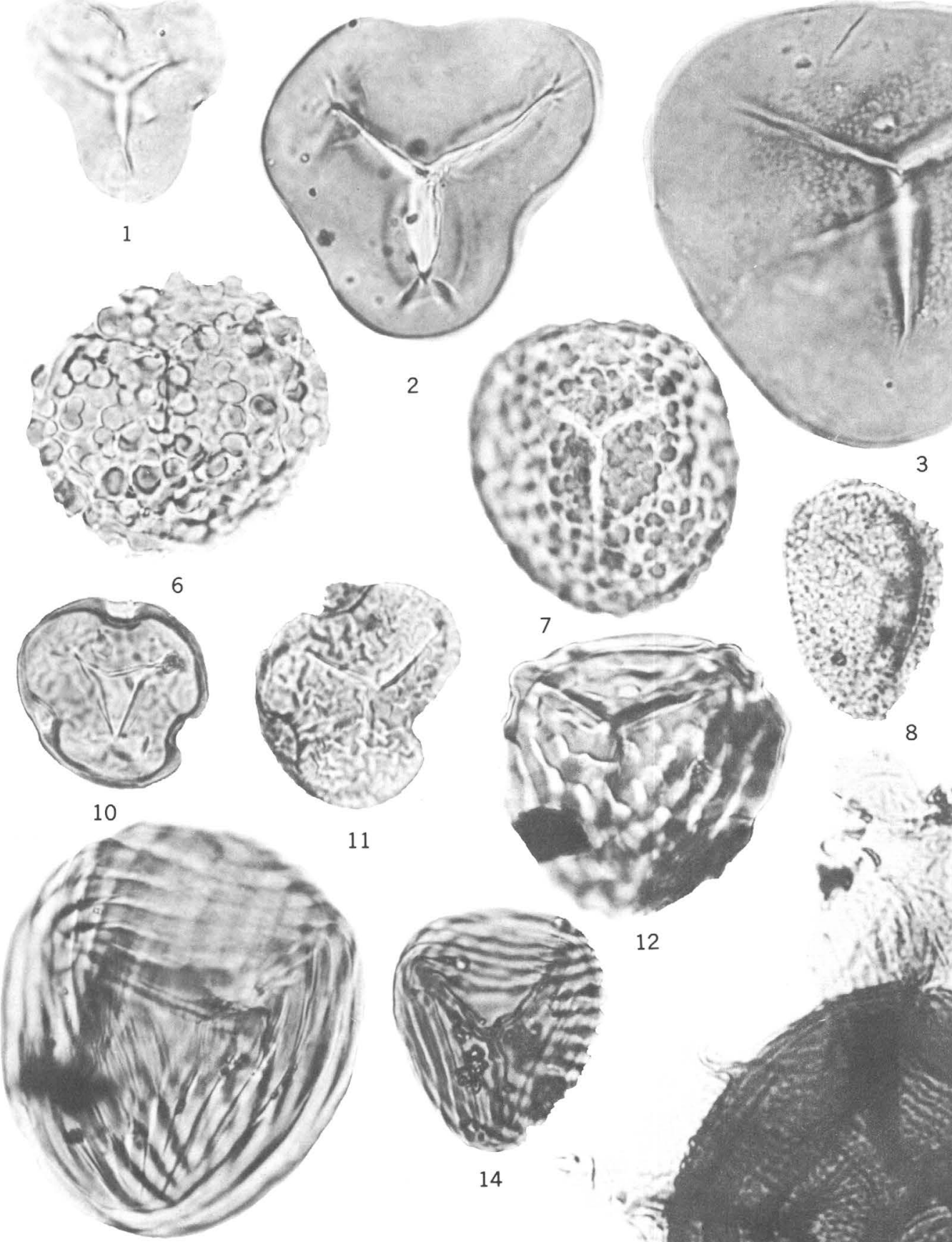

11
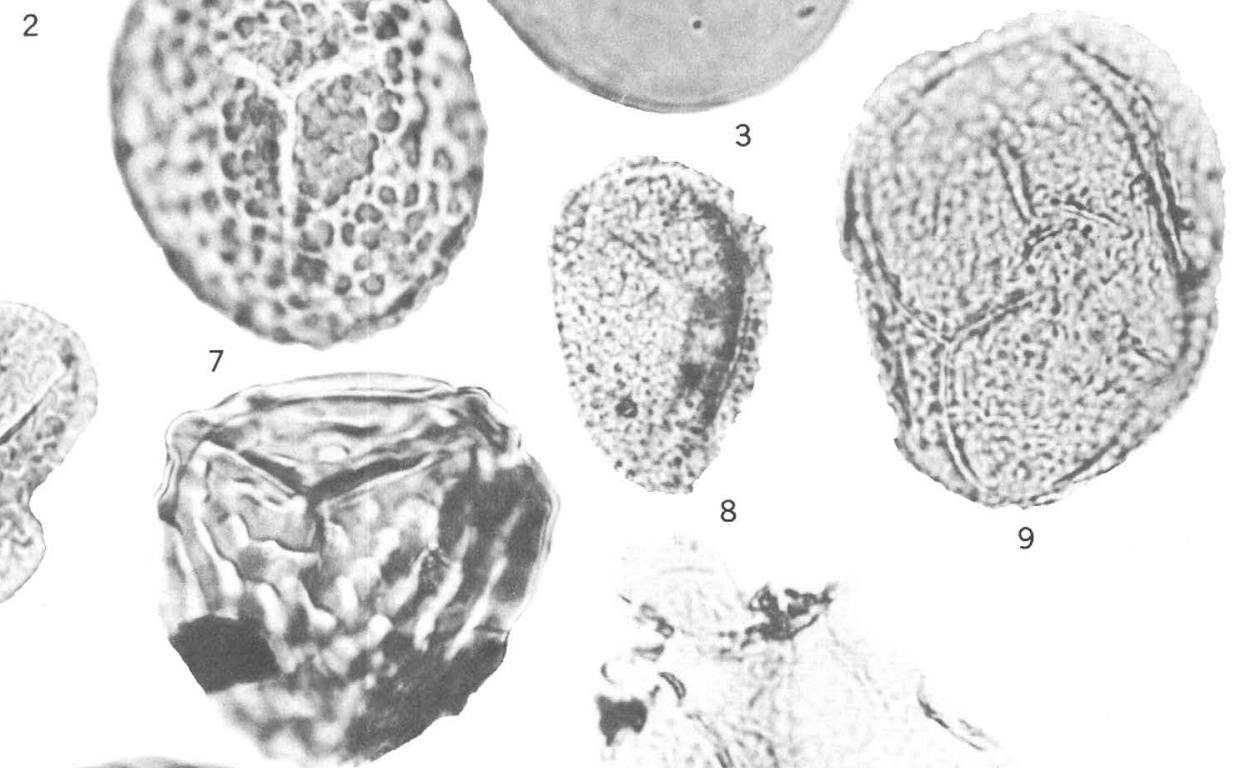

13

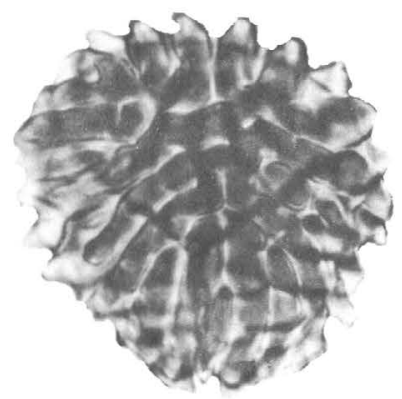

15

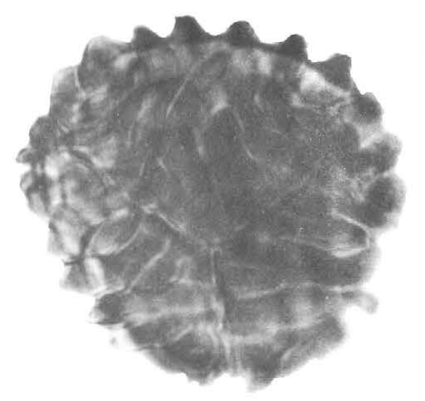

16

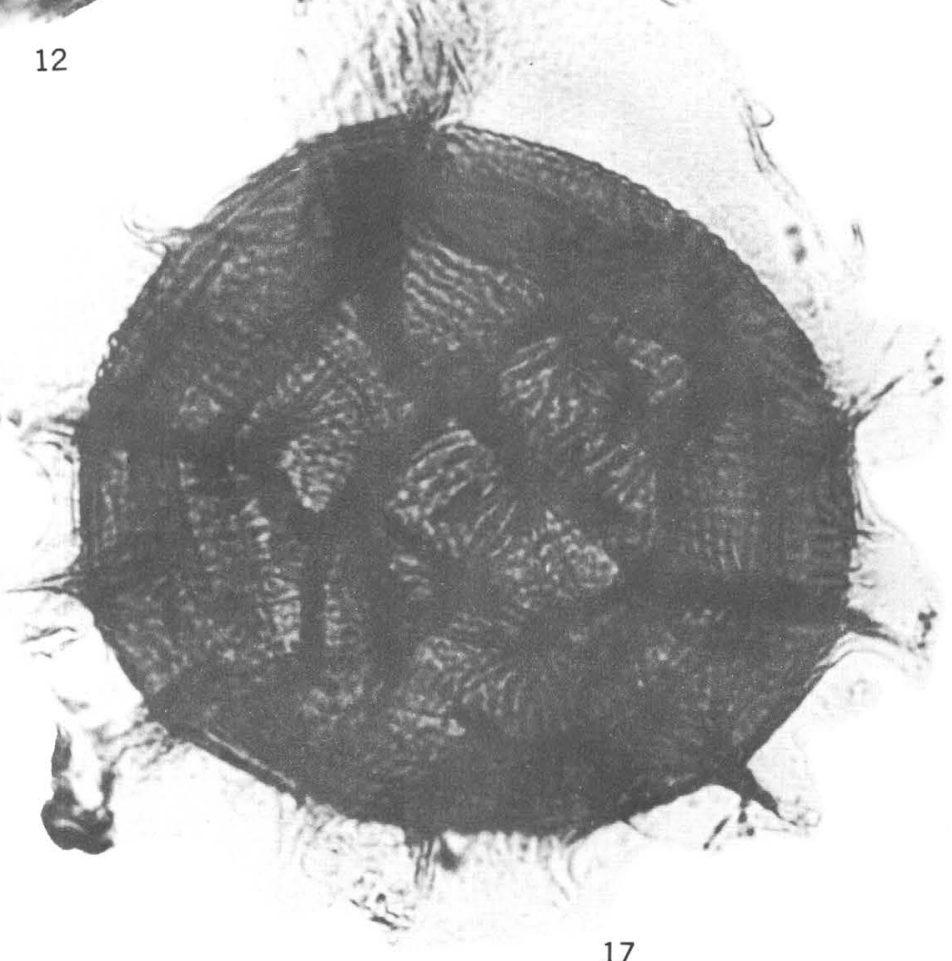

CYATHIDITES, DELTOIDOSPORA, STEREISPORITES, LEPTOLEPIDITES, BACULATISPORITES, OSMUNDACIDITES, KUYLISPORITES, ISCHYOSPORITES. CICATRICOSISPORITES, AND GHOSHISPORA 


\section{PLATE 2}

[All figures $\times 1,000$ ]

Figures 1,2. Foraminisporis wonthaggiensis (Cookson and Dettmann) Dettmann

(p. 8).

1. USGS paleobotany loc. D3726-D, slide $(2)$ at $78.8 \times 5.6$.

2. USGS paleobotany loc. D3725-A, slide (2) at $92.6 \times 21.3$.

3-5. Polycingulatisporites spp. (p. 8).

3. USGS paleobotany loc. D3726-E, slide (4) at $99.8 \times 3.7$.

4. USGS paleobotany loc. D3726-E, slide (9) at $99.4 \times 8.8$.

5. USGS paleobotany loc. D3726-C, slide $(2)$ at $83.1 \times 21.7$.

6-10. Trisolissporites montanensis n. sp. (p. 9).

6, 7. Holotype, two focal levels. USGS paleobotany loc. D3726-E, slide (3) at $99.9 \times 11.3$.

8. Paratype. USGS paleobotany loc. D3726-E, slide (2) at 81.8 $\times 11.2$.

9, 10. Two focal levels. USGS paleobotany loc. D3726-E, slide, (1) at $118.8 \times 1.8$.

11. Dulhuntyispora dulhuntyi Potonié (p. 9).

Specimen from Upper Permian from Western Australia, furnished by Dr. B. E. Balme.

12-14. Trisolissporites chlonovae (Döring) n. comb. (p. 10).

12. USGS paleobotany loc. D3726-E, slide (2) at $93.0 \times 8.9$.

13. USGS paleobotany loc. D3726-E, slide (8) at $77.8 \times 14.1$.

14. USGS paleobotany loc. D3726-E, slide $(2)$ at $117.3 \times 5.6$. 
GEOLOGICAL SURVEY
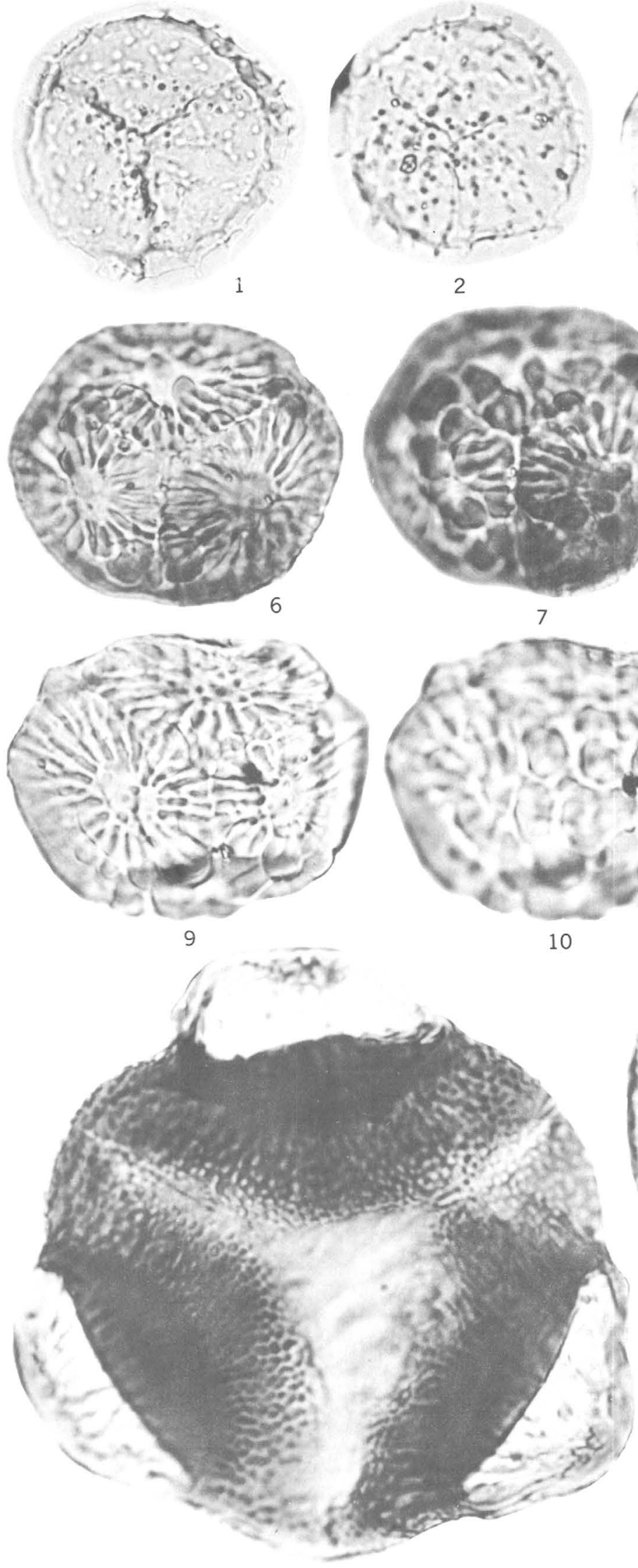

11
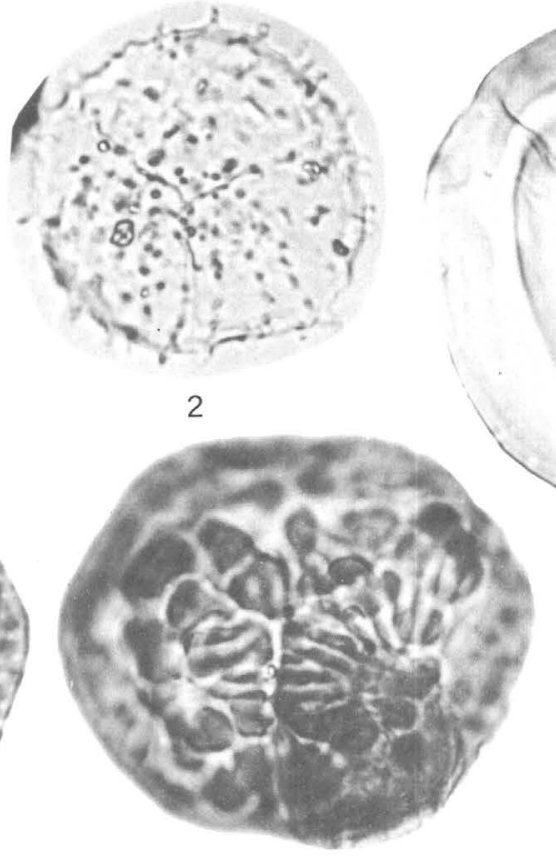

7
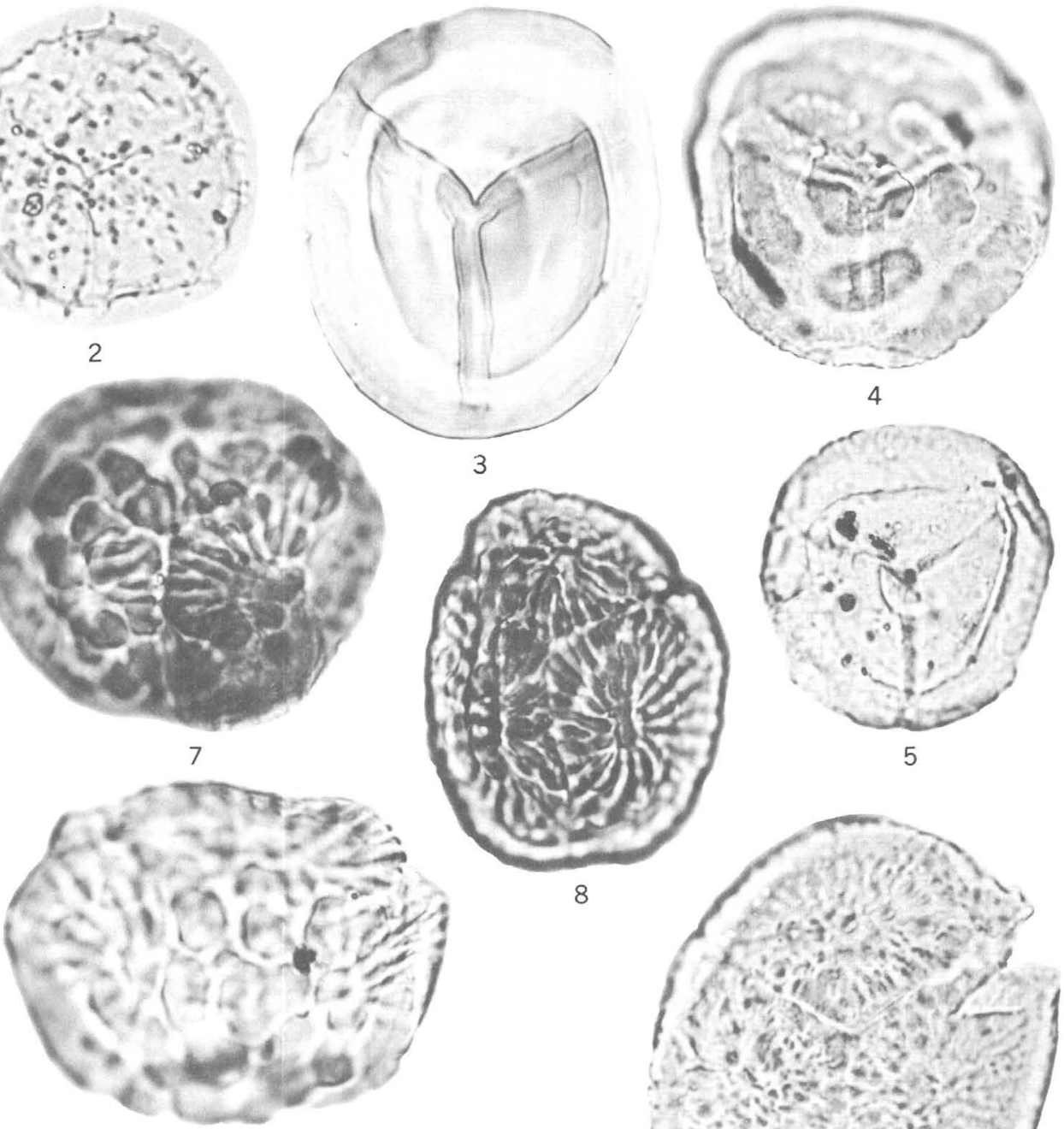

5

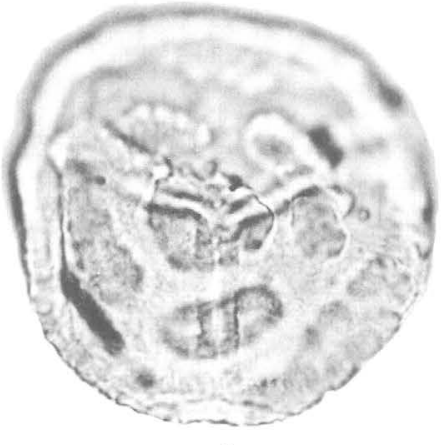

4 


\section{PLATE 3}

[All figures $\times 1,000]$

FIgURES 1-4. Gleicheniidites spp. (p. 11).

1. USGS paleobotany loc. D3726-E, slide (4) at $87.4 \times 19.8$.

2. USGS paleobotany loc. D4067, slide (4) at $92.6 \times 12.2$.

3. USGS paleobotany loc. D4067, slide (4) at $100.9 \times 21.1$.

4. USGS paleobotany loc. D4067, slide (4) at $112.0 \times 16.4$.

5,6. Camarozonosporites spp. (p. 11).

5. USGS paleobotany loc. D3726-D, slide (1) at $80.9 \times 8.0$.

6. USGS paleobotany loc. D4067, slide $(10)$ at $111.1 \times 4.1$.

7,8. Laevigatosporites spp. (p. 11).

7. USGS paleobotany loc. D3726-A, slide (2) at $109.7 \times 7.3$

8. USGS paleobotany loc. D3726-A, slide (2) at $100.8 \times 4.3$.

9,10. Umbosporites callosus Newman (p. 11).

9. USGS paleobotany loc. D4069, slide (1) at $91.9 \times 5.0$.

10. USGS paleobotany loc. D3726-C, slide (1) at $82.7 \times 3.7$.

11. Microfoveolatosporis canaliculatus Dettemann (p. 11).

USGS paleobotany loc. D3726-E, slide (4) at $104.7 \times 5.3$.

12-17. Seductisporites gemmiferus n. sp. (p. 11).

12, 13. Holotype, two focal levels. USGS paleobotany loc. D3726A, slide (2) at $96.7 \times 19.8$.

14, 15. Paratype, two focal levels, USGS paleobotany loc. D3726-A, slide (1) at $91.4 \times 14.1$.

16, 17. Paratype, two focal levels. USGS paleobotany loc. D3726A, slide (2) at $92.4 \times 18.3$. 


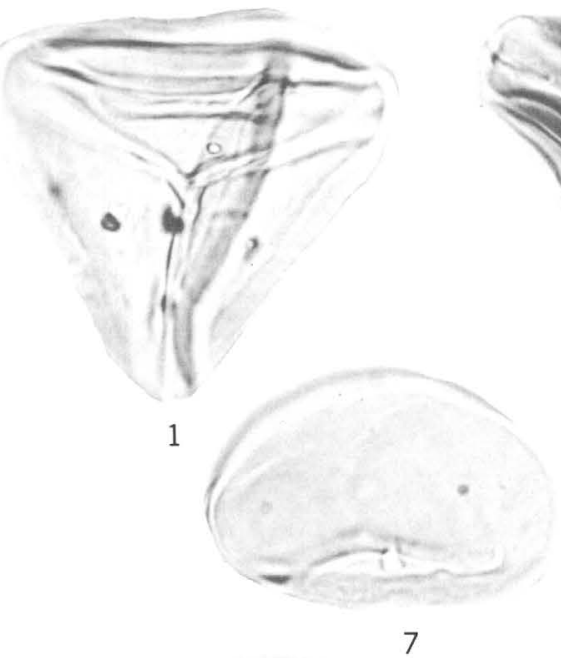

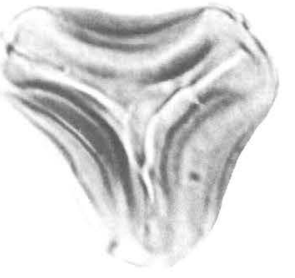

2

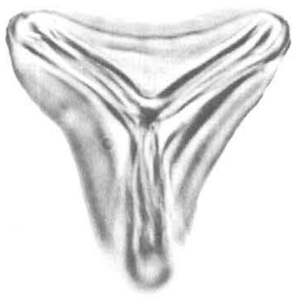

3

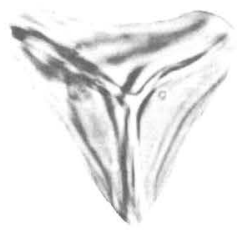

4
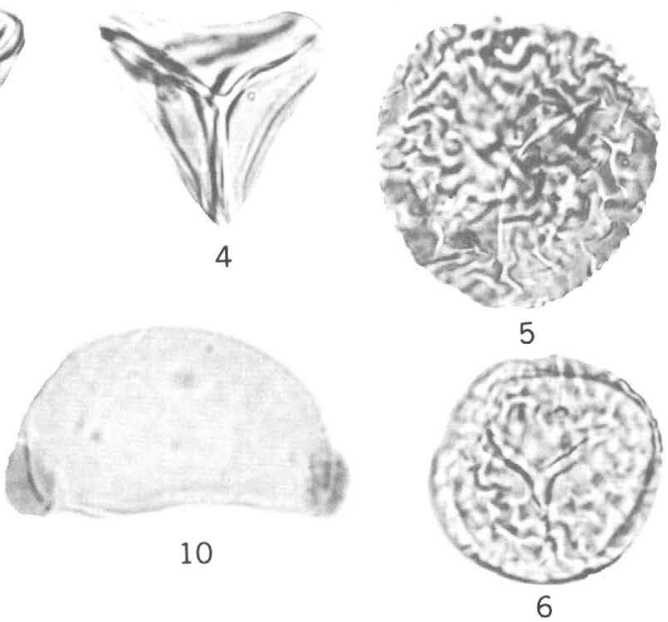

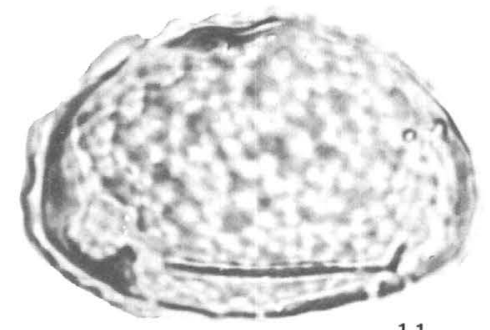

11
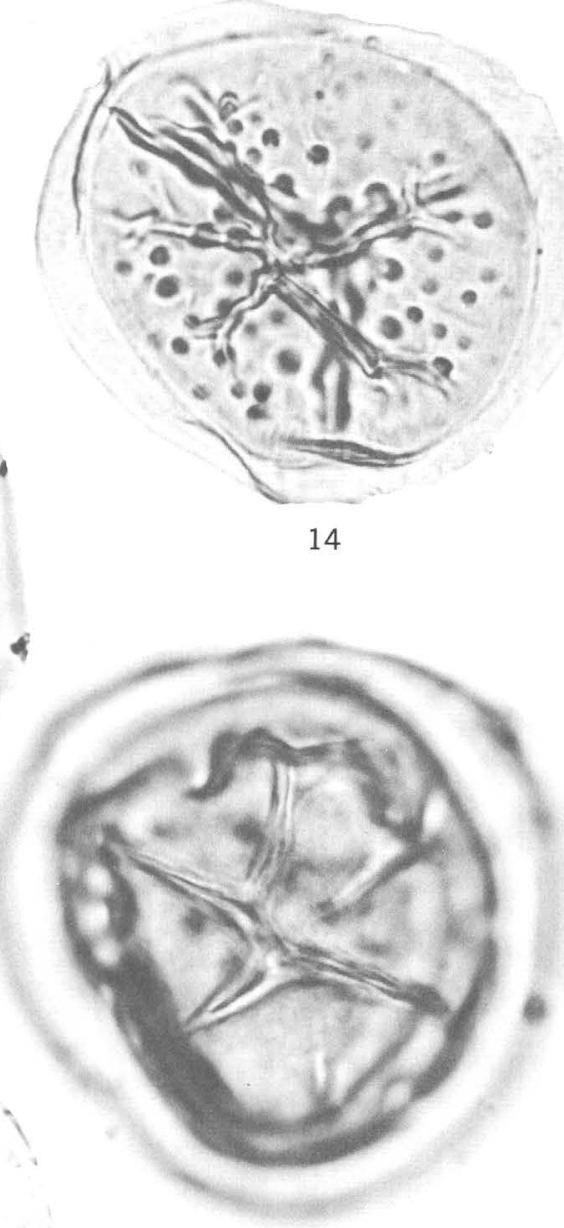

17

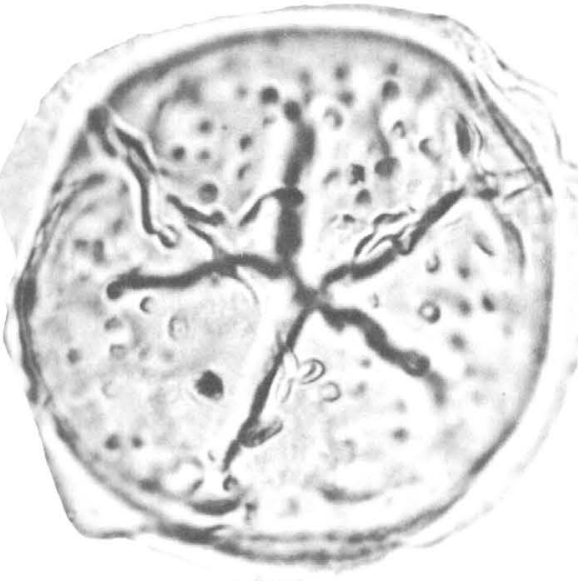

15
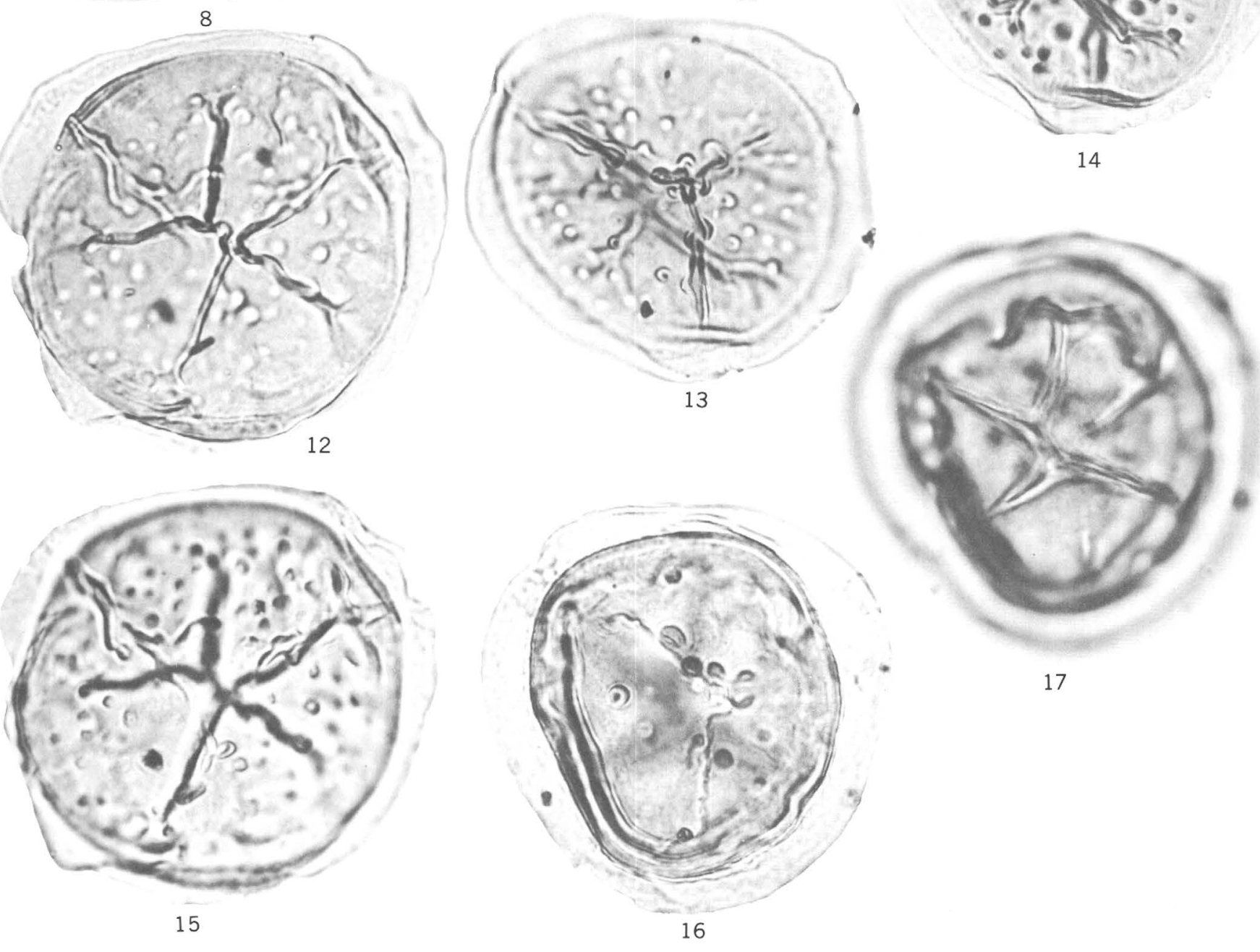

12

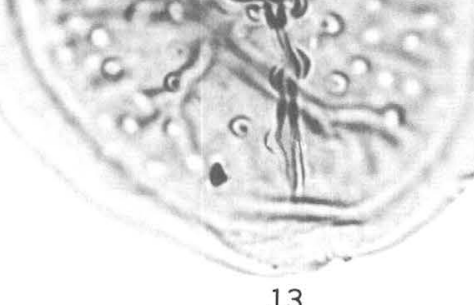

GLEICHENIIDITES, CAMAROZONOSPORITES, LAEVIGATOSPORITES, UNBOSPORITES, MICROFOVEOLATOSPORIS, AND SEDUCTISPORITES 


\section{PLATE 4}

[All figures $\times 1,000$ ]

Figures 1-3. Seductisporites eminens n. sp. (p. 12).

1. Holotype, USGS paleobotany loc. D3726-E, slide (5) at $99.0 \times$ 10.3 .

2. Paratype, USGS paleobotany loc. D3726-E, slide (9) at $84.8 \times$ 16.1.

3. Paratype. USGS paleobotany loc. D3726-E, slide (8) at 109.2 $\times 19.7$.

4-7. Seductisporites barbatus n. sp. (p. 13).

4. Holotype. USGS paleobotany loc. D3726-E, slide (9) at $111.3 \times$ 3.2 .

5. Paratype. USGS paleobotany loc. D3726-E, slide (7) at 82.0 $\times 12.5$.

6, 7. Paratype, two focal levels. USGS paleobotany loc. D3726-E, slide (10) at $94.5 \times 7.7$. 

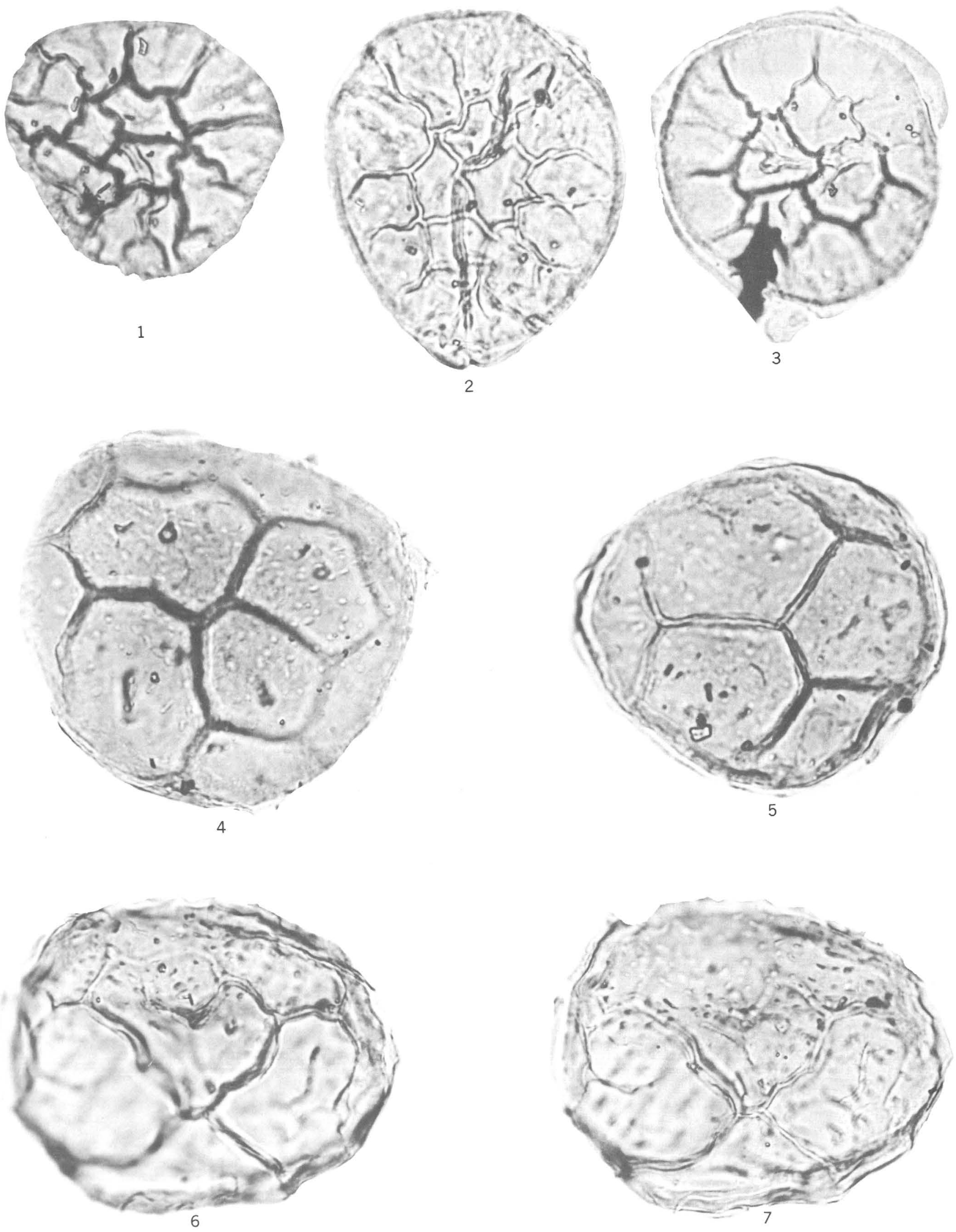

SEDUCTISPORITES 


\section{PLATE 5}

[All figures $\times 1,000$ ]

Figure 1. Zonalapollenites sp. (p. 14).

USGS paleobotany loc. D3726-E, slide (4) at $100.8 \times 21.6$.

2,3. Alisporites grandis (Cookson) Dettmann (p. 14).

2. USGS paleobotany loc. D3726-E, slide (5) at $117.5 \times 2.5$.

3. USGS paleobotany loc. D3726-E, slide (6) at $102.2 \times 8.8$.

4,5. Alisporites thomasii (Couper) Nilsson (p. 14).

4. USGS paleobotany loc. D3726-E, slide (6) at $106.9 \times 15.1$.

5. USGS paleobotany loc. D3726-E, slide (6) at $97.3 \times 10.5$.

6. Abietineaepollenites varius Norton (p. 15).

USGS paleobotany loc. D3726-A, slide (2) at $90.1 \times 12.0$.

7. Cedripites parvus Norton (p. 15).

USGS paleobotany loc. D3726-E, slide $(8)$ at $107.8 \times 9.9$.

8. Cedripites cretaceus Pocock (p. 15).

USGS paleobotany loc. D3726-C, slide (2) at $110.3 \times 7.2$.

9. Pityosporites cf. P. constrictus (p. 15).

USGS paleobotany loc. D3726-E, slide (6) at $113.2 \times 6.7$. 

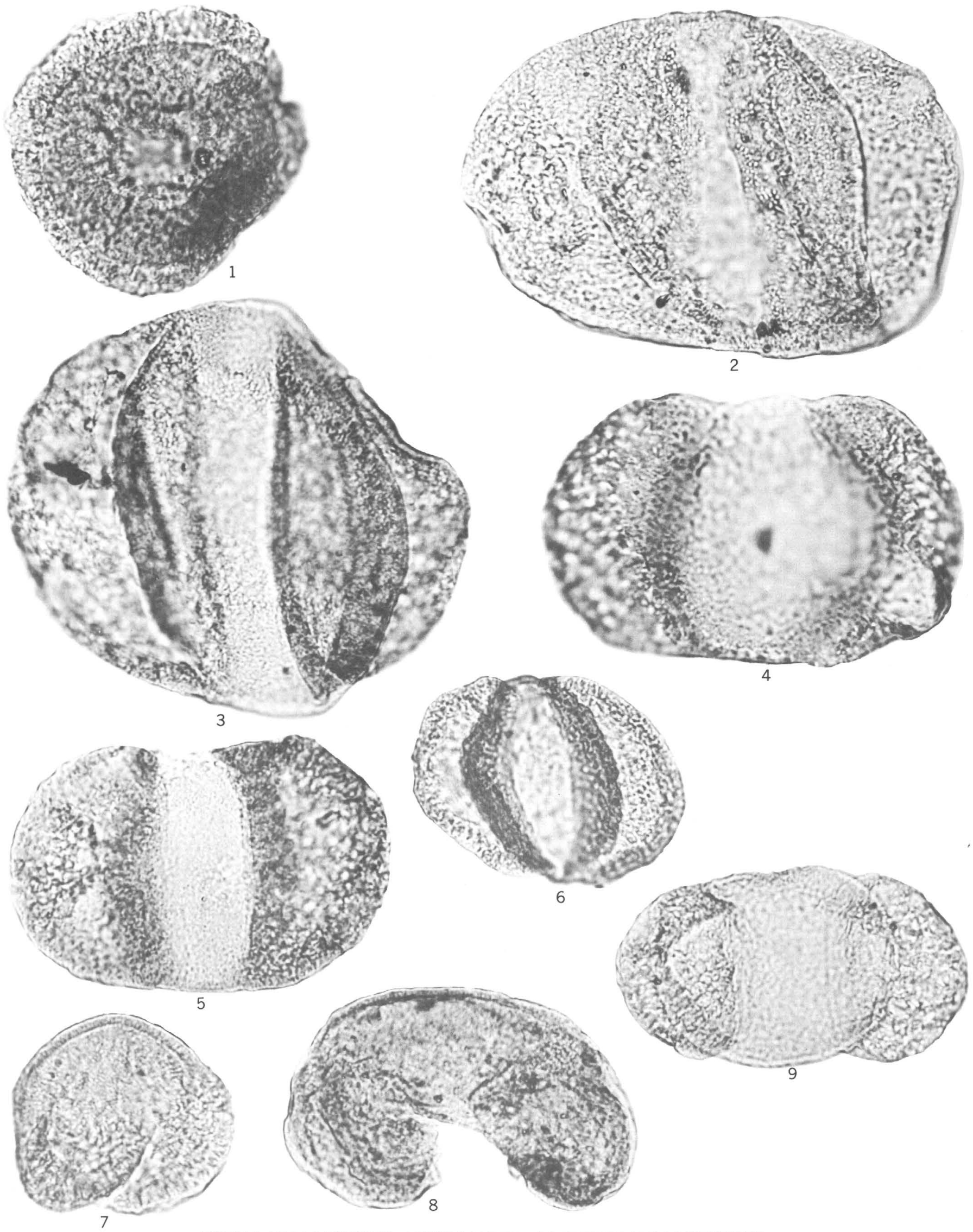

ZONALAPOLLENITES, ALISPORITES, ABIETINEAEPOLLENITES,

CEDRIPITES, AND PITYOSPORITES 


\section{PLATE 6}

[All figures $\times 1,000$ ]

FIGURE 1. Pityosporites alatipollenites (Rouse) Singh (p. 15).

USGS paleobotany loc. D3726-A, slide (2) at $86.0 \times 8.3$.

2-4. Pityosporites elongatus (Norton) Tschudy var. elongatus ( $p .15)$.

2,3. Two focal levels. USGS paleobotany loc. D3726-E, slide (6) at $107.7 \times 8.6$.

4. USGS paleobotany loc. D3726-E, slide (6) at $104.1 \times 2.7$.

5,6. Pityosporites elongatus var. grandis n. var. (p. 15).

5. Paratype. USGS paleobotany loc. D3726-E, slide (6) at $96.9 \times$ 13.2.

6. Holotype. USGS paleobotany loc. D3726-E, slide (5) at $116.0 \times$ 4.9. 

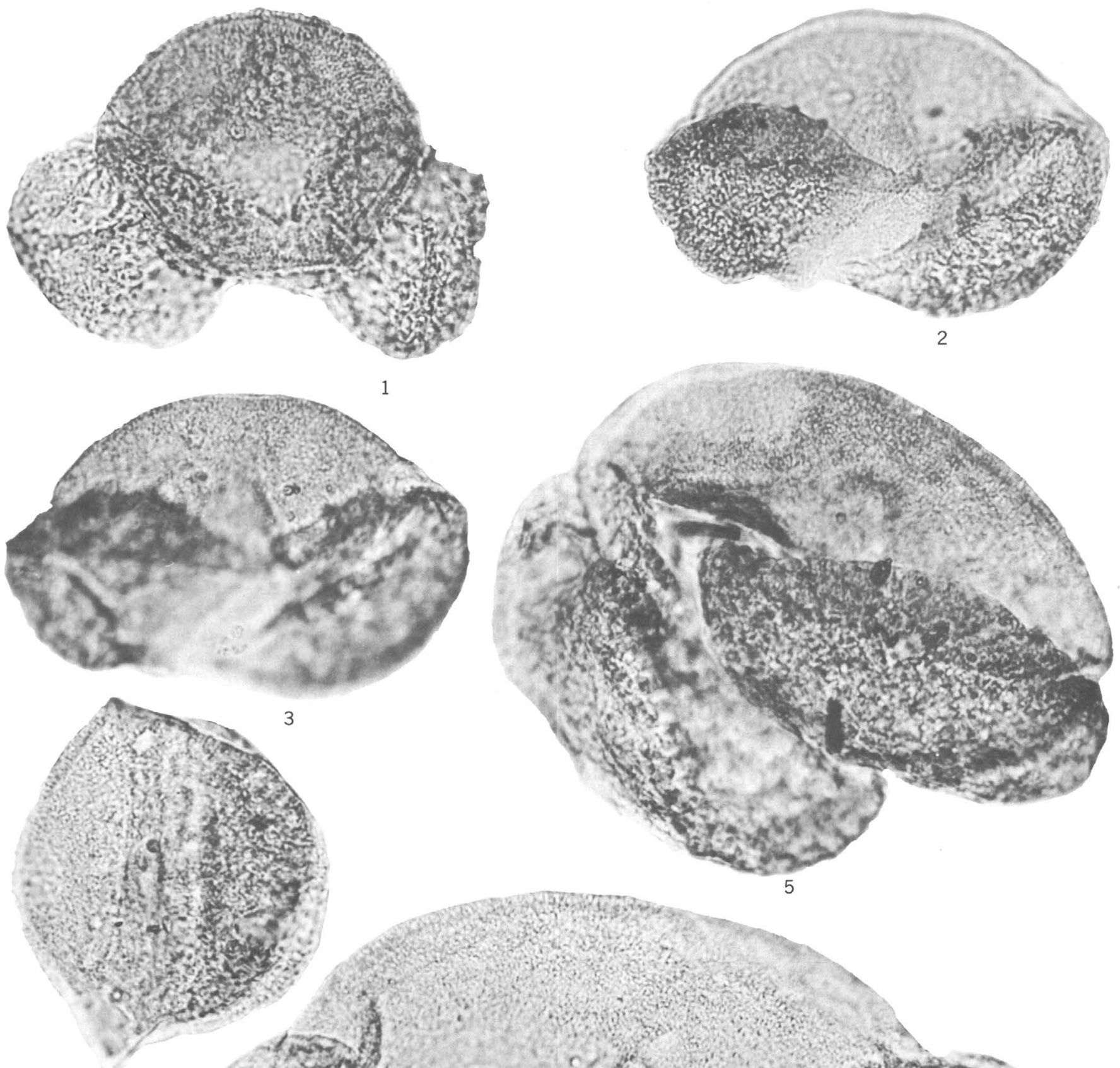

4

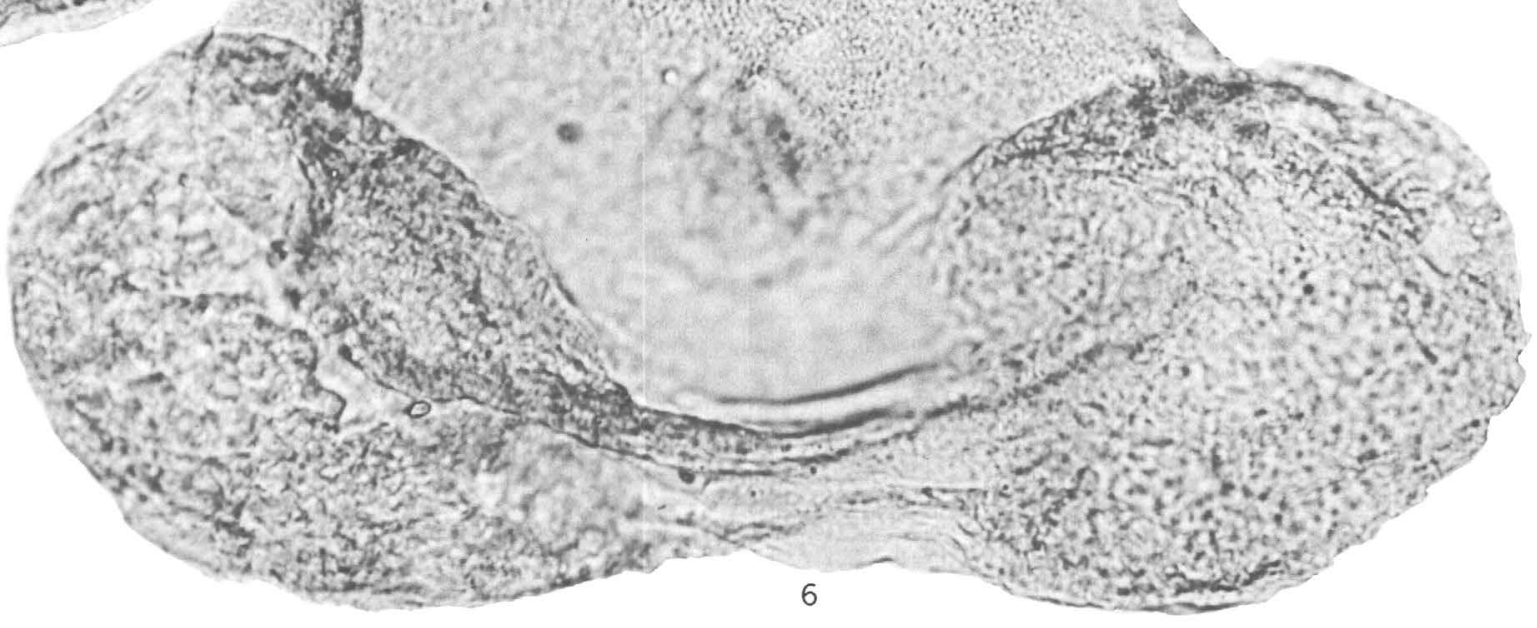

PITYOSPORITES 


\section{PLATE 7}

[All figures $\times 1,000$ ]

Figures 1, 2. Podocarpidites multesimus (Bolkhovitina) Pocock (p. 16).

1. USGS paleobotany loc. D3726-E, slide (6) at $99.0 \times 22.2$.

2. USGS paleobotany loc. D3726-E, slide (8) at $95.2 \times 11.2$.

3. Podocarpidites cf. P. ornatus (p. 16).

USGS paleobotany loc. D3725-A, slide $(2)$ at $82.0 \times 19.1$.

4-6. Pristinuspollenites microsaccus (Couper) n. comb. (p. 16, 17).

4. USGS paleobotany loc. D3726-E, slide (6) at $108.8 \times 21.2$.

5. USGS paleobotany loc. D3726-E, slide (4) at $87.2 \times 8.0$.

6. USGS paleobotany loc. D3726-A, slide $(2)$ at $99.4 \times 19.2$.

7. Pristinuspollenites (Bacubivesiculites) inchoatus (Pierce) n. comb. (p. 16).

Holotype. (Also see Pierce 1961, pl. II, fig. 35).

8,9. Pristinuspollenites (Clavabivesiculites inchoatus Pierce) crassus n. name (p. 16).

Holotype, two focal levels. (See Clavabivesiculites inchoatus Pierce, 1961, pl. II, g. 36.)

10. Pristinuspollenites (Clavabivesiculites) pannosus (Pierce) n. comb. (p. 17).

Holotype. (Also see Pierce, 1961, pl. II, fig. 37.)

11. Pristinuspollenites (Granabivesiculties inchoatus Pierce) sulcatus $\mathrm{n}$. name (p. 17).

Holotype. (See Granabivesiculites inchoatus Pierce, 1961, pl. II, fig. 38.)

12, 13. Rugubivesiculites sp. (p. 18).

12. USGS paleobotany loc. D3726-E, slide (6) at $92.2 \times 11.9$.

13. USGS paleobotany loc. D3725-A, slide (2) at $106.9 \times 3.9$. 

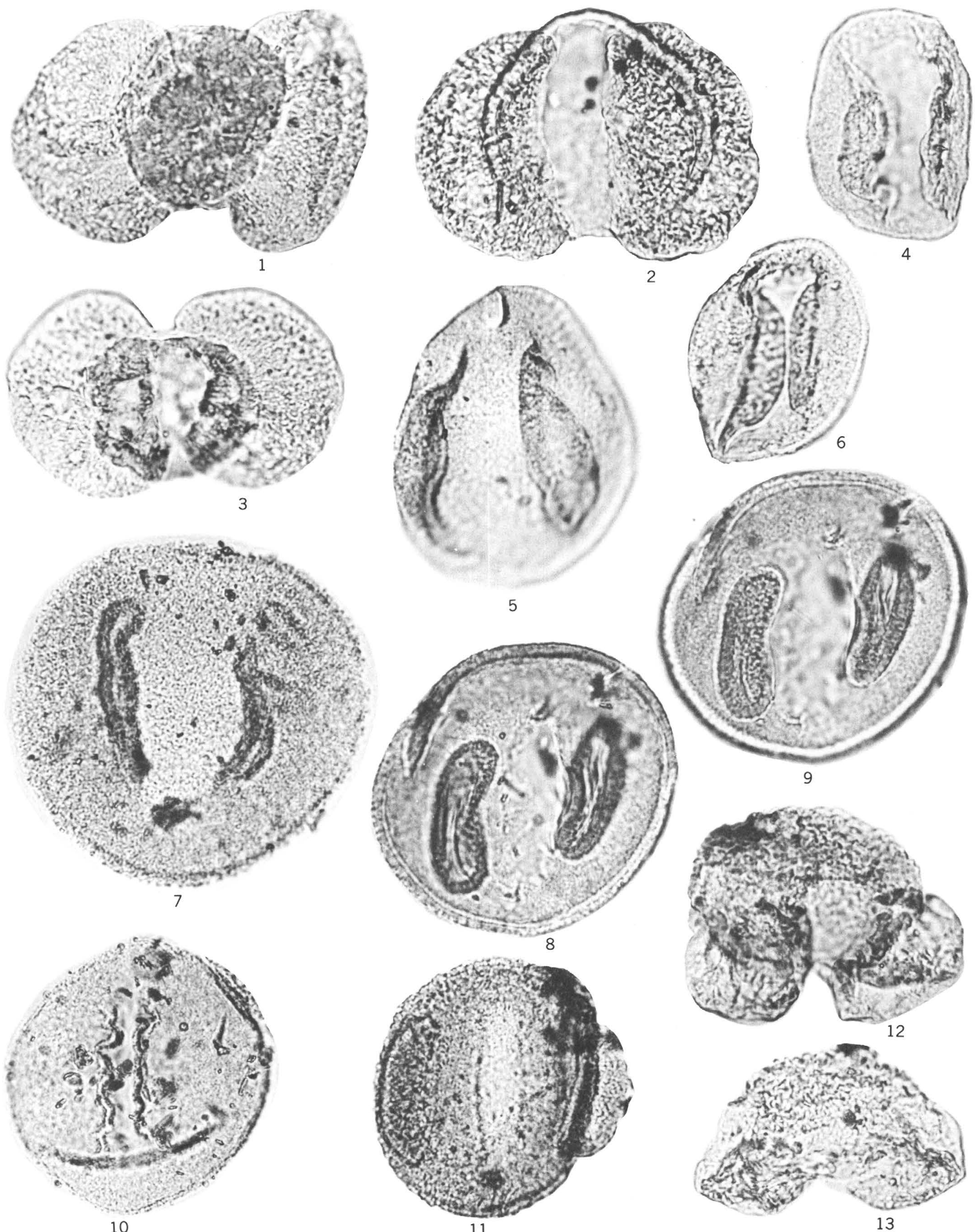

PODOCARPIDITES, PRISTINUSPOLLENITES, AND RUGUBIVESICULITES 


\section{PLATE 8}

[All figures $\times 1,000]$

FIgURES 1,2. Vitreisporites pallidus (Reissinger) Nilsson (p. 18).

1. USGS paleobotany loc. D3726-B, slide (1) at $73.3 \times 5.9$.

2. USGS paleobotany loc. D3726-D, slide $(2)$ at $97.2 \times 12.0$.

3,4. Taxodiaceaepollenites hiatus (Potonié) Kremp ex Potonié (p. 19).

3. USGS paleobotany loc. D3726-D, slide $(2)$ at $80.9 \times 4.1$.

4. USGS paleobotany loc. D3725-D, slide $(2)$ at $88.1 \times 2.7$.

5,6. Sequoiapollenites spp. (p. 20).

5. USGS paleobotany loc. D3726-E, slide (4) at $89.2 \times 18.8$.

6. USGS paleobotany loc. D3726-D, slide (2) at $104.5 \times 18.6$.

7,8. Classopollis spp. (p 20).

7. USGS paleobotany loc. D3725-E, slide (2) at $84.9 \times 18.2$.

8. USGS paleobotany loc. D3726-C, slide $(2)$ at $115.3 \times 18.5$.

9,10. Equisetosporites spp. (p. 20).

9. USGS paleobotany loc. D3726-E, slide (6) at $84.9 \times 5.0$.

10. USGS paleobotany loc. D4067, slide (1) at $86.9 \times 21.2$.

11. Arecipites sp. (p. 20).

USGS palebotany loc. D3725-C, slide $(4)$ at $81.0 \times 17.8$.

12. Liliacidites variegatus Couper (p. 20).

USGS paleobotany loc. D3725-C, slide (2) at $111.8 \times 11.0$.

13. Liliacidites cf. L. morrinensis (p. 20).

USGS paleobotany loc. D4070, slide (2) at $102.8 \times 5.3$.

14, 15. Liliacidites complexus (Stanley) n. comb. (p. 20).

14. USGS paleobotany loc. D4067, slide (1) at $105.1 \times 20.1$.

15. USGS paleobotany loc. D4069, slide (2) at $87.0 \times 2.1$.

16-18. Liliacidites spp. (p. 21).

16. USGS paleobotany loc. D3726-A, slide (2) at $92.2 / \times 2.3$.

17. USGS paleobotany loc. D3726-A, slide (2) at $90.8 \times 4.2$.

18. USGS paleobotany loc. D3725-C, slide $(5)$ at $91.3 \times 22.1$.

19. Ovoidites ligneolus (Potonié) Potonié ex Krutzsch (p. 21).

USGS paleobotany loc. D3725-C, slide (5) at $96.0 \times 18.2$.

20, 21. Aesculiidites dubius (Jardiné and Magloire) n. comb. (p. 21).

Two focal levels. USGS paleobotany loc. D3726-B, slide (1) at $105.4 \times 15.7$.

22-25. Grewipollenites radiatus n. sp. (p. 21).

22. Holotype. USGS paleobotany loc. D3726-D, slide (2) at $104.7 \times 18.8$.

23. Paratype. USGS paleobotany loc. D3726-D, slide (2) at 86.0 $\times 15.3$.

24. Paratype. USGS paleobotany loc. D3726-D, slide (2) at 88.1 $\times 4.1$.

25. USGS paleobotany loc. D3726-D, slide (2) at $80.6 \times 14.7$.

26-28. Pulcheripollenites krempii Srivastava (p. 22).

26. USGS paleobotany loc. D3725-C, slide (2) at $86.5 \times 3.8$.

27. USGS paleobotany loc. D3725-C, slide (4) at $85.9 \times 10.6$.

28. USGS paleobotany loc. D3725-C, slide (2) at $96.5 \times 18.9$.

29-31. Tricolpites reticulatus Cookson (p. 23).

29. USGS paleobotany loc. D3725-D, slide (2) at $93.4 \times 5.2$.

30. USGS paleobotany loc. D3726-E, slide (6) at $104.6 \times 12.6$.

31. USGS paleobotany loc. D3726-E, slide (6) at $90.6 \times 10.7$.

32-34. Tricolpites hians Stanley (p. 24).

32. USGS paleobotany loc. D3726-E, slide (3) at $104.8 \times 18.1$.

33. USGS paleobotany loc. D3726-A, slide (2) at $85.8 \times 8.0$.

34. USGS paleobotany loc. D3726-E, slide (3) at $110.0 \times 7.4$.

35-37. Tricolpites spp. (p. 24).

35. USGS paleobotany loc. D3725-C, slide (4) at $80.4 \times 2.5$.

36. USGS paleobotany loc. D4069, slide (1) at $108.0 \times 5.5$.

37. USGS paleobotany loc. D4070, slide $(2)$ at $100.1 \times 3.5$. 
GEOLOGICAL SURVEY
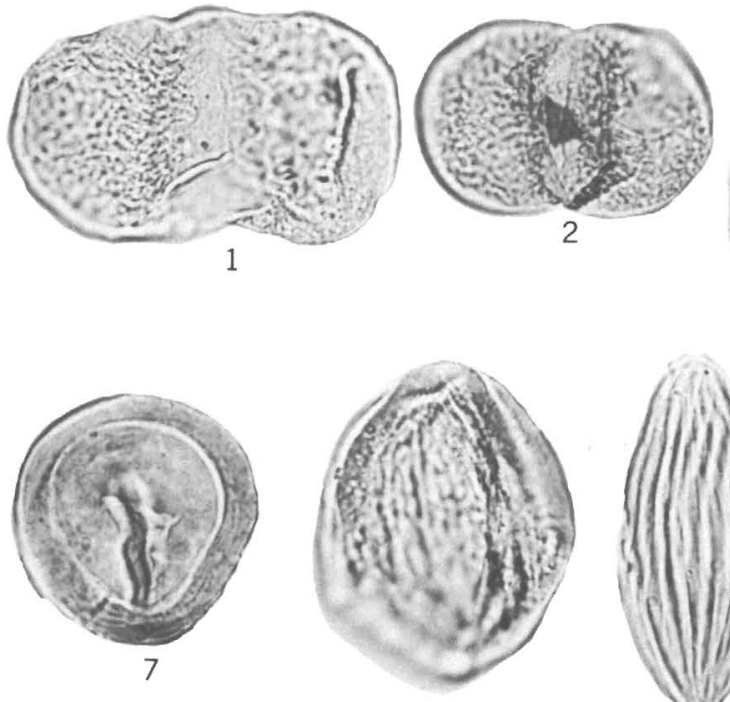

8
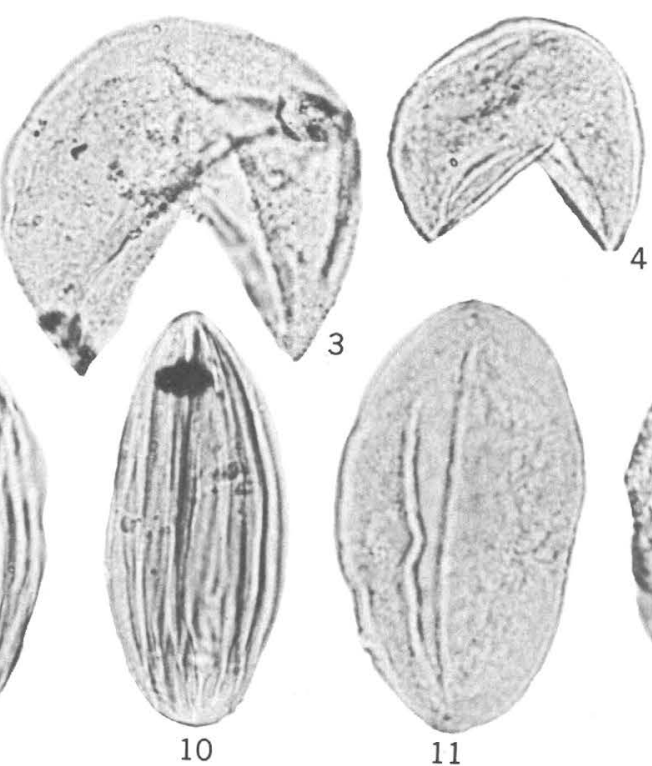

PROFESSIONAL PAPER 770 PLATE 8

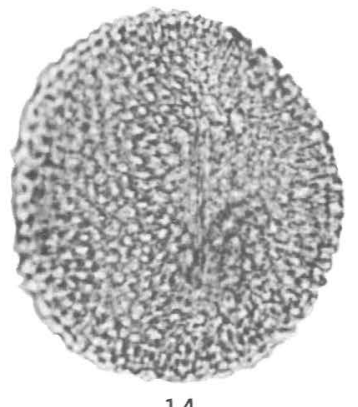

14
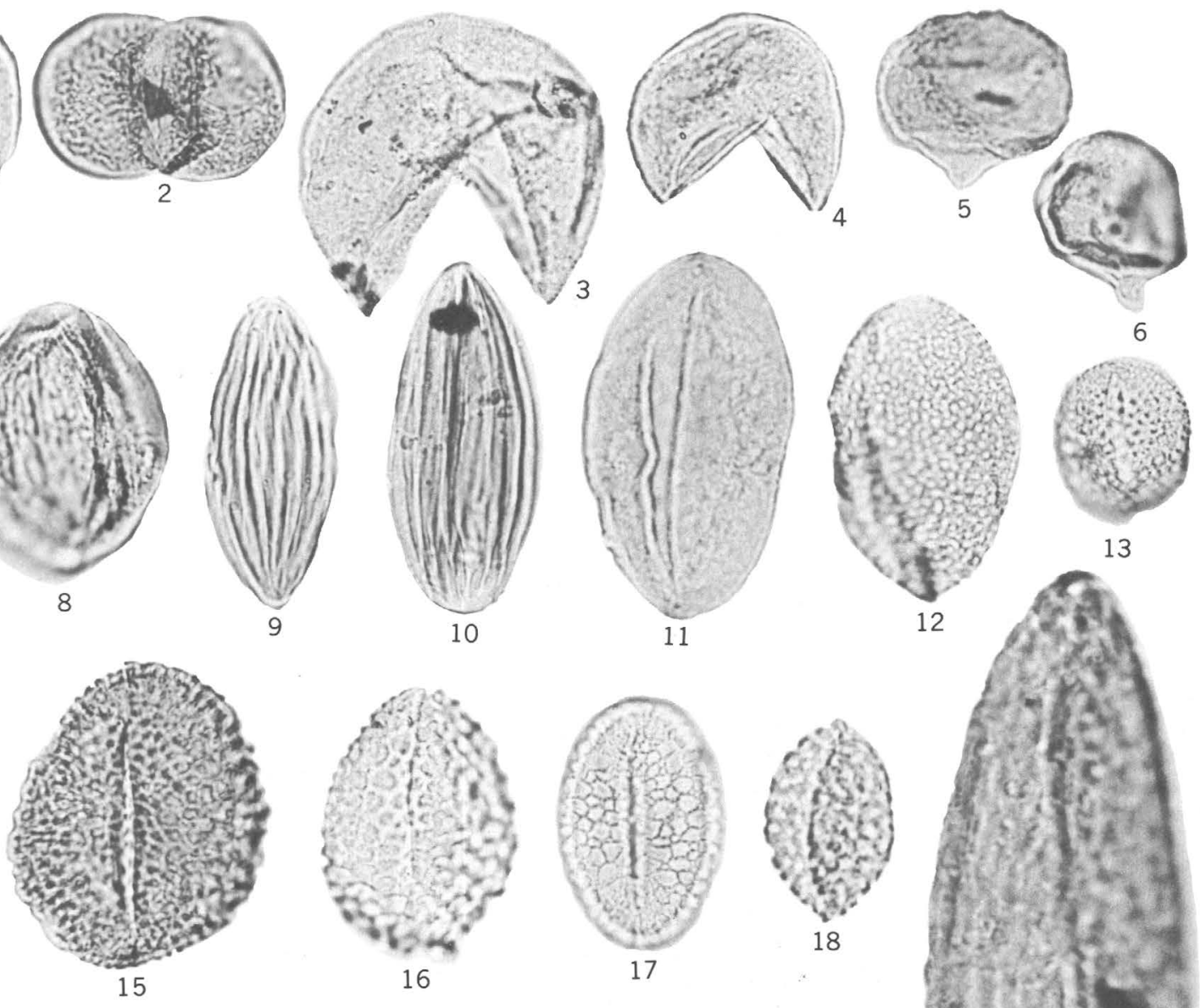

13
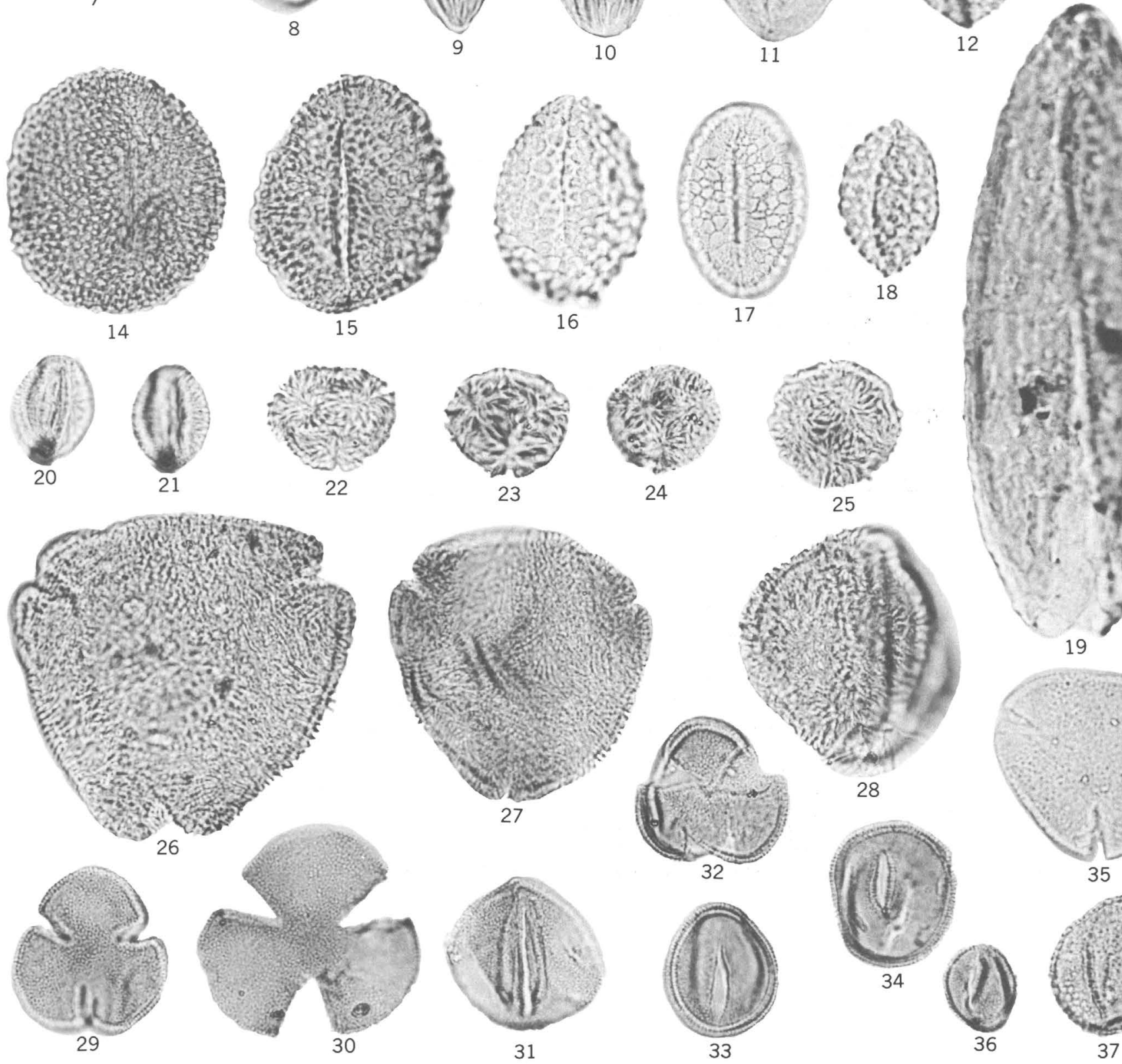

25
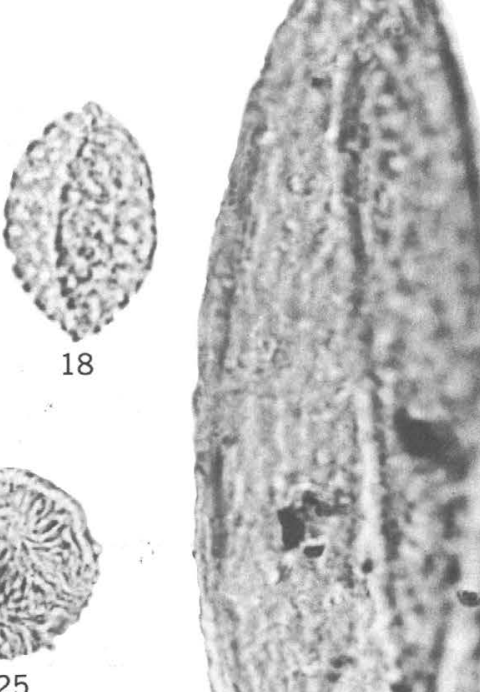


\section{PLATE 9}

[All figures $\times 1,000]$

Figures

1-6. Tricolpopollenites levitas n. sp. (p. 25).

1. Holotype. USGS paleobotany loc. D3725-C, slide (2) at 113.2 $\times 3.8$.

2,3. Paratype, two focal levels. USGS paleobotany loc. D3725-C, slide (4) at $80.9 \times 6.8$.

4. Paratype. USGS paleobotany loc. D3725-C, slide (4) at 84.4 $\times 11.3$

5. USGS paleobotany loc. D3725-C, slide (4) at $83.8 \times 11.2$.

6. USGS paleobotany loc. D3725-C, slide $(3)$ at $96.1 \times 5.4$.

7,8. Tricolpopollenites tessellatus n. sp. (p. 25).

7. USGS paleobotany loc. D4067, slide (1) at $103.4 \times 16.4$.

8. Holotype. USGS paleobotany loc. D3725-E, slide (2) at 107.6 $\times 8.9$.

9. Cranwellia rumseyensis Srivastava (p. 26).

USGS paleobotany loc. D3725-C, slide (4) at $83.1 \times 14.0$.

10-12. Cranwellia bacata Srivastava (p. 26).

10,11. Two focal levels. USGS paleobotany loc. D4067, slide (1) at $77.2 \times 9.7$.

12. USGS paleobotany loc. D4067, slide (3) at $87.8 \times 16.1$.

13. Cf. Cranwellia (p. 26).

USGS paleobotany loc. D3725-A, slide $(2)$ at $100.7 \times 2.5$.

14-16. Fibulapollis scabratus Tschudy (p. 26).

14, 15. Two focal levels. USGS paleobotany loc. D3726-E, slide (4) at $85.7 \times 14.3$.

16. USGS paleobotany loc. D3726-D, slide (2) at $87.3 \times 6.2$.

17, 18. Aquilapollenites quadrilobus Rouse (p. 27).

17. USGS paleobotany loc. D3725-C, slide (4) at $110.3 \times 3.7$.

18. USGS paleobotany loc. D4067, slide $(12)$ at $88.1 \times 8.0$.

19. Aquilapollenites senonicus (Mtchedlishvili) Tschudy and Leopold (p. 27).

USGS paleobotany loc. D3725-C, slide $(2)$ at $97.8 \times 5.3$.

20. Aquilapollenites trialatus Rouse var. uniformis Tschudy and Leopold (p. 27).

USGS paleobotany loc. D3725-C, slide (4) at $90.4 \times 8.7$.

21. Aquilapollenites clarireticulatus (Samoilovitch) Tschudy (p. 27). USGS paleobotany loc. D4069, slide (3) at $112.5 \times 8.5$.

22-24. Aquilapollenites trialatus Rouse (p. 27).

22. USGS paleobotany loc. D3726-E, slide (6) at $82.3 \times 12.3$.

23. USGS paleobotany loc. D3726-B, slide (1) at $86.5 \times 14.9$.

24. USGS paleobotany loc. D3726-E, slide (4) at $96.2 \times 7.2$.

25. Aquilapollenites reticulatus (Mtchedlishvili) Tschudy and Leopold (p. 27).

USGS paleobotany loc. D3726-D, slide (2) at $104.6 \times 12.1$.

26. Aquilapollenites sp. (p. 27).

USGS paleobotany loc. D3725-C, slide (5) at $83.5 \times 20.2$. 


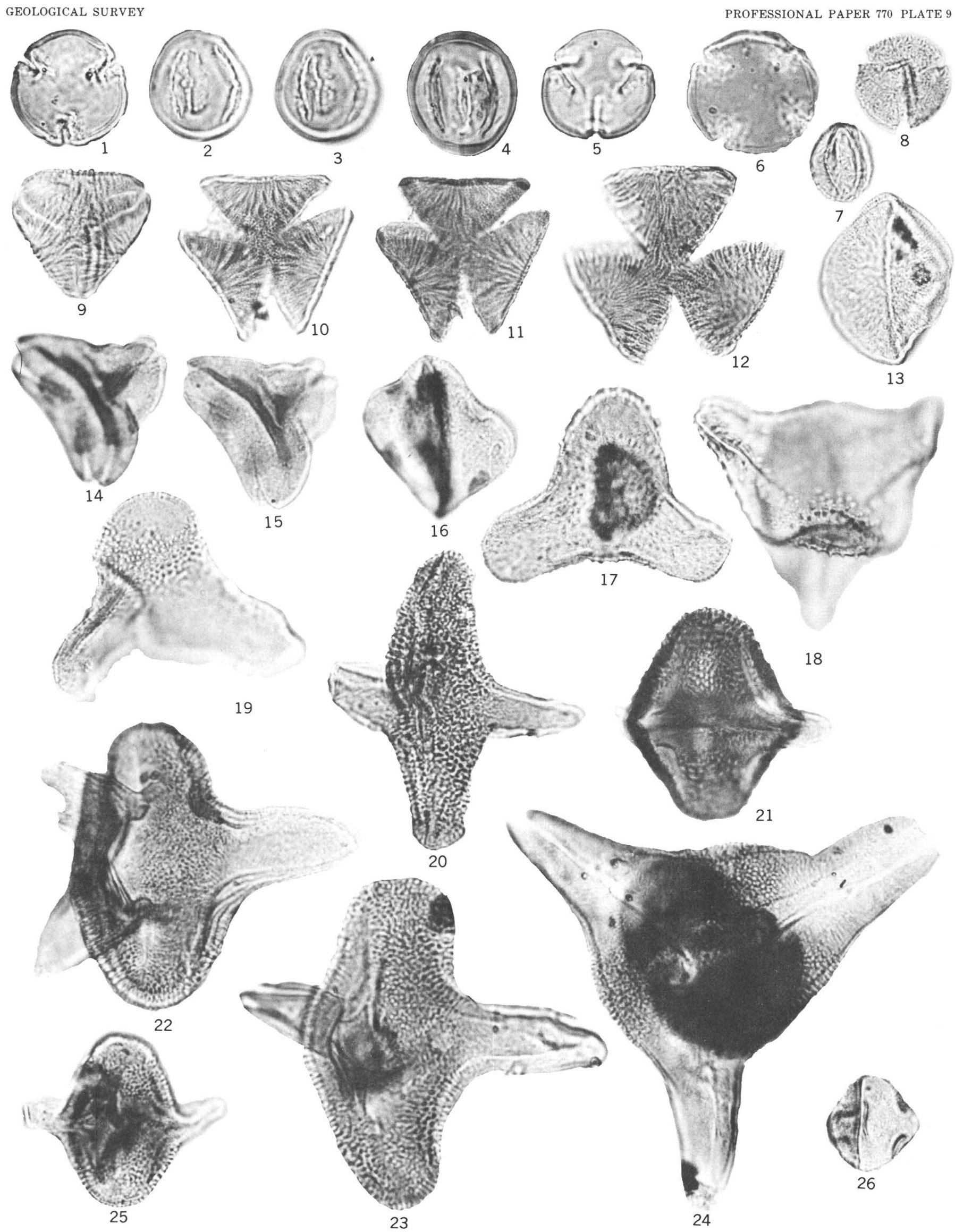

TRICOLPOPOLLENITES, CRANWELLIA, FIBULAPOLLIS, AND AQUILAPOLLENITES 


\title{
PLATE 10
}

\author{
[All figures $\times 1,000]$
}

Figures 1,2. Aquitapollenites turbidus Tschudy and Leopold (p. 27).

1. USGS paleobotany loc. D3726-E, slide (6) at $108.6 \times 19.7$.

2. USGS paleobotany loc. D3726-C, slide (2) at $107.5 \times 10.8$.

3-6. Aquilapollenites attenuattus Funkhouser (p. 27).

3. USGS paleobotany loc. D3725-C, slide (4) at $81.8 \times 15.4$.

4. USGS paleobotany loc. D3725-C, slide (2) at $107.4 \times 18.5$.

5. USGS paleobotany loc. D3725-C, slide (4) at $86.0 \times 17.7$.

6. USGS paleobotany loc. D4067, slide (3) at $77.1 \times 10.5$.

7-9. Mancicorpus calvus (Tschudy and Leopold) n. comb. (p. 29).

7. USGS paleobotany loc. D3725-C, slide (4) at $79.2 \times 17.8$.

8. USGS paleobotany loc. D3725-C, slide (4) at $85.7 \times 22.3$.

9. USGS paleobotany loc. D3726-C, slide (5) at $109.5 \times 10.1$.

10,11. Mancicorpus tripodiformis (Tschudy and Leopold) n. comb. (p. 29).

10. USGS paleobotany loc. D4069, slide (4) at $97.5 \times 10.1$.

11. USGS paleobotany loc. D3725-A, slide (2) at $89.0 \times 15.9$.

12-16. Sindorapollis granulatus n. sp. (p. 30).

12. Holotype. USGS paleobotany loc. D4069, slide (1) at $106.5 \times$ 10.5 .

13. Paratype. USGS paleobotany loc. D4069, slide (2) at $104.3 \times$ 3.6.

14. Paratype. USGS paleobotany loc. D4069, slide (1) at 105.7 $\times 18.7$.

15. USGS paleobotany loc. D4069, slide (4) at $83.8 \times 16.1$.

16. USGS paleobotany loc. D4069, slide (1) at $82.5 \times 22.3$.

17. Cupanieidites sp. (p. 30).

USGS paleobotany loc. D3726-E, slide (4) at $87.6 \times 16.4$.

18-21. Tricolporites rhomboides Anderson (p. 30).

18. USGS paleobotany loc. D3725-C, slide (5) at $110.3 \times 2.9$.

19. USGS paleobotany loc. D3725-C, slide (2) at $112.9 \times 13.6$.

20. USGS paleobotany loc. D3725-C, slide (4) at $108.3 \times 20.2$.

21. USGS paleobotany loc. D3725-C, slide (4) at $99.9 \times 6.0$.

22. Tricolporites sp. (p. 31).

USGS paleobotany loc. D4070, slide $(2)$ at $101.6 \times 13.5$. 

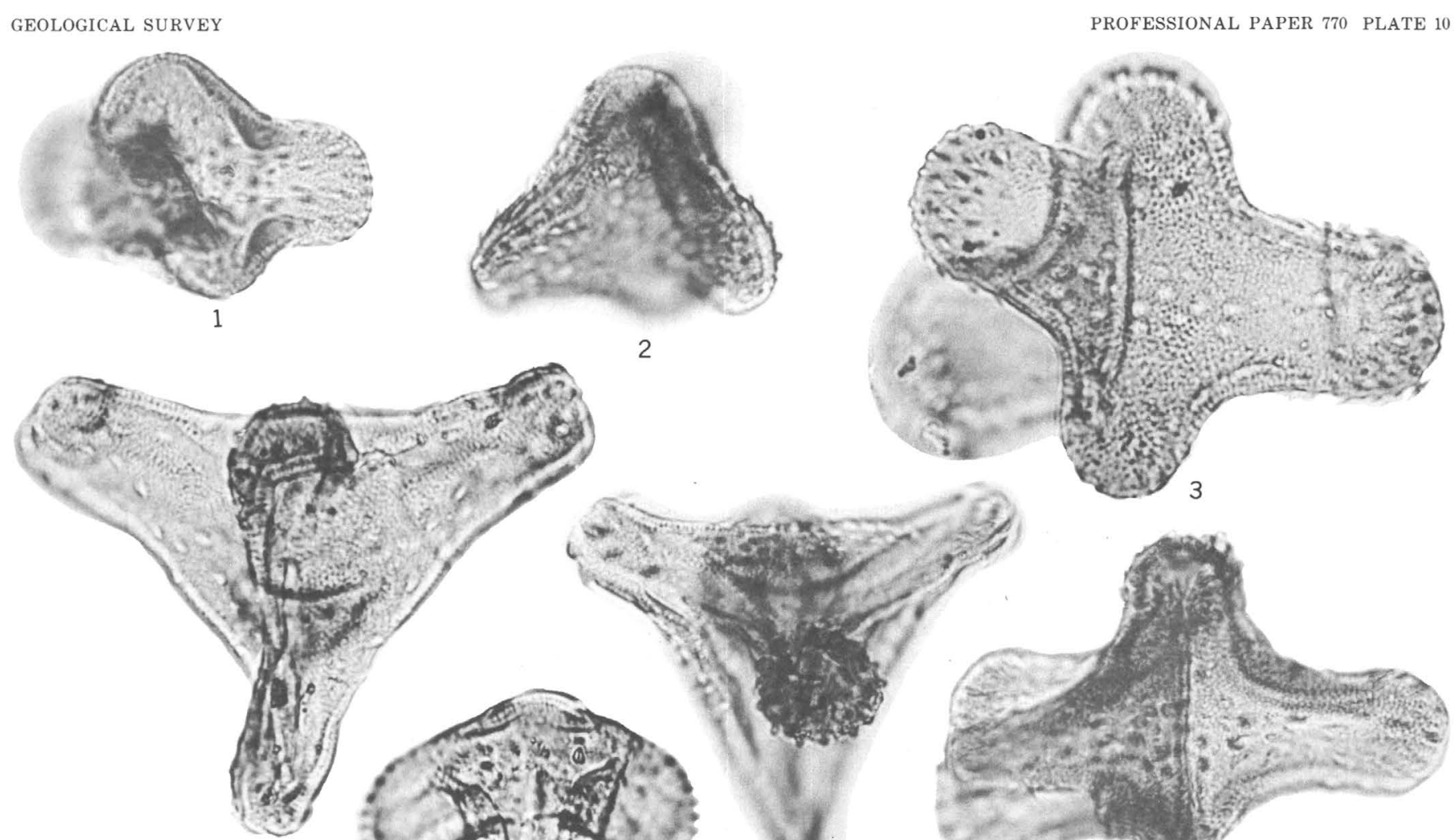

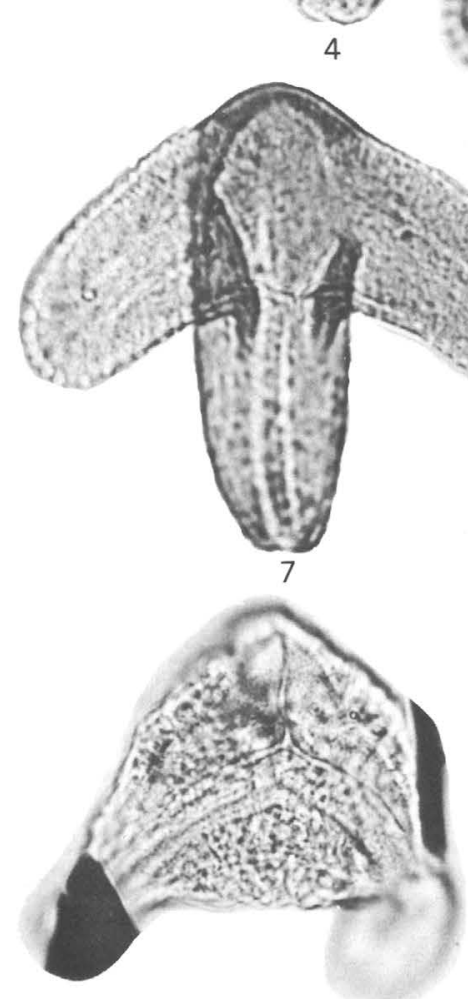

11

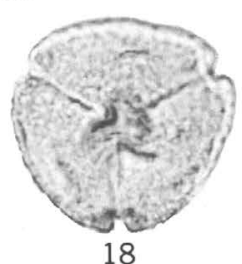

2

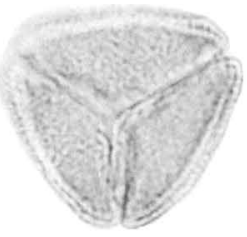

17
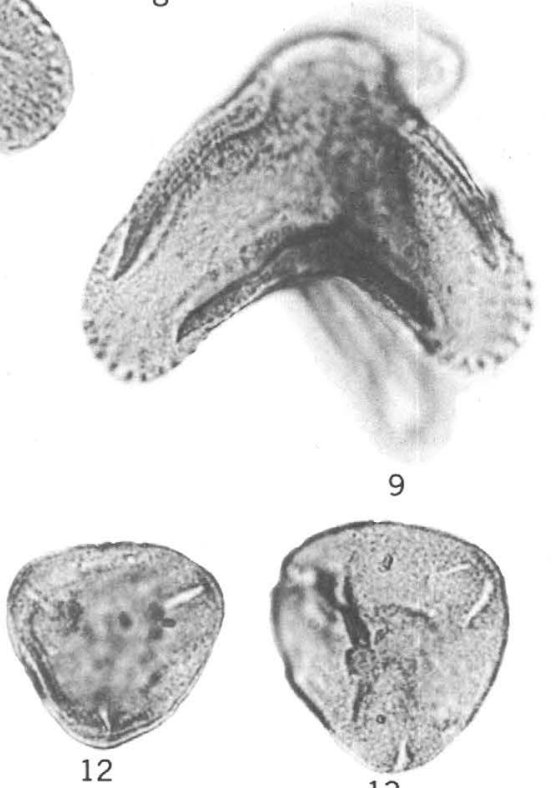

9

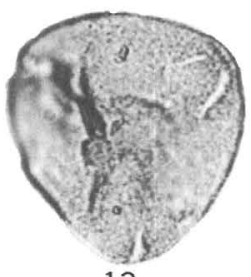

13
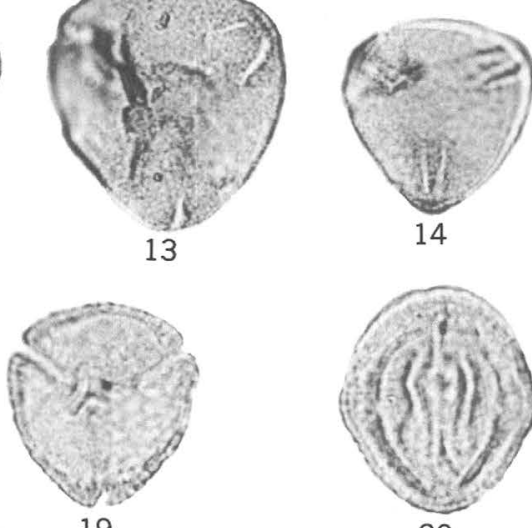

19

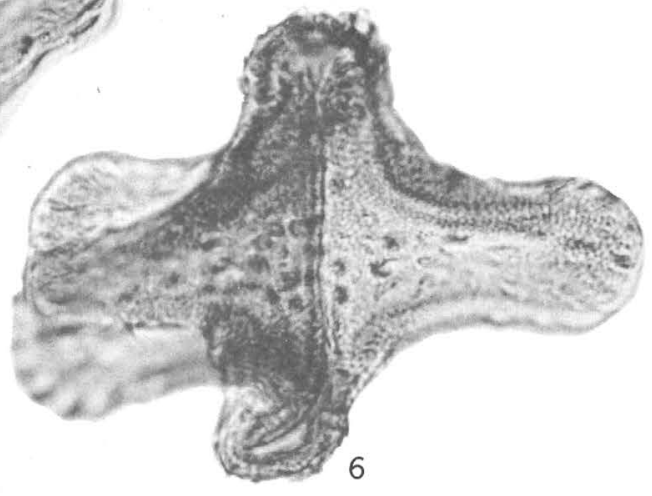

AQUILAPOLLENITES, MANCICORPUS, SINDORAPOLLIS, CUPANIEIDITES, AND TRICOLPORITES 


\section{PLATE 11}

[All figures $\times 1,000]$

Figure 1. Montanapollis endannulatus Tschudy (p. 31).

USGS paleobotany loc. D4067, slide (10) at $83.9 \times 8.0$.

2,3. Siberiapollis montanensis Tschudy (p. 31).

2. USGS paleobotany loc. D3726-E, slide (5) at $91.1 \times 14.0$.

3. USGS paleobotany loc. D3726-E, slide $(8)$ at $82.5 \times 6.9$.

4, 5. Triatriopollenites costatus Norton (p. 31).

4. USGS paleobotany loc. D3726-A, slide (1) at $91.8 \times 11.3$.

5. USGS paleobotany loc. D3726-E, slide (4) at $95.3 \times 16.0$.

6-8. Subtriporopollenites alpinus (Wolf) n. comb. (p. 31).

6. USGS paleobotany loc. D3725-C, slide (4) at $102.8 \times 6.2$.

7. USGS paleobotany loc. D3725-C, slide (2) at $96.7 \times 14.3$.

8. USGS paleobotany loc. D4067, slide (2) at $90.1 \times 18.2$.

9-12. Proteacidites spp. (p. 32).

9. USGS paleobotany loc. D4069, slide (2) at $113.5 \times 7.1$.

10. USGS paleobotany loc. D4069, slide (1) at $86.3 \times 4.1$.

11. USGS paleobotany loc. D4067, slide (1) at $82.2 \times 4.7$.

12. USGS paleobotany loc. D4067, slide (3) at $104.0 \times 1.7$.

13. Periporopollenites sp. (p. 32).

USGS paleobotany loc. D3726-C, slide (1) at $101.9 \times 11.9$.

14. Erdtmanipollis pachysandroides Krutzsch (p. 32).

USGS paleobotany loc. D4067, slide (10) at $79.2 \times 3.1$.

15-17. Dyadonapites reticulatus n. sp. (p. 32).

15. Holotype. USGS paleobotany loc. D3725-C, slide (4) at $85.0 \times$ 6.0.

16. Paratype. USGS paleobotany loc. D3725-C, slide (5) at $91.0 \times$ 17.1.

17. USGS paleobotany loc. D3725-D, slide (1) at $91.0 \times 14.8$.

18, 19. Inaperturotetradites scabratus $\mathrm{n}$. sp. (p. 32).

18. Holotype. USGS paleobotany loc. D3725-A, slide $(2)$ at $96.3 \times 4.1$.

19. USGS paleobotany loc. D3725-E, slide (2) at $79.4 \times 14.4$.

20. Droseridites cf. D. spinulosus (p. 33).

USGS paleobotany loc. D3726-E, slide (3) $88.5 \times 17.2$. 

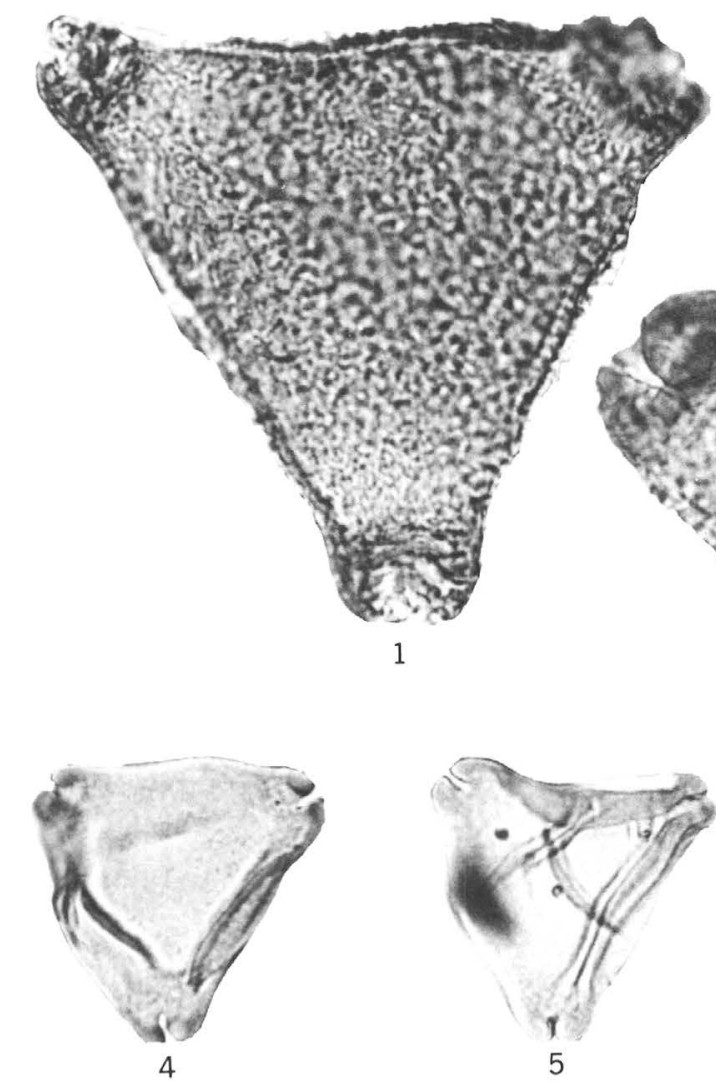

1
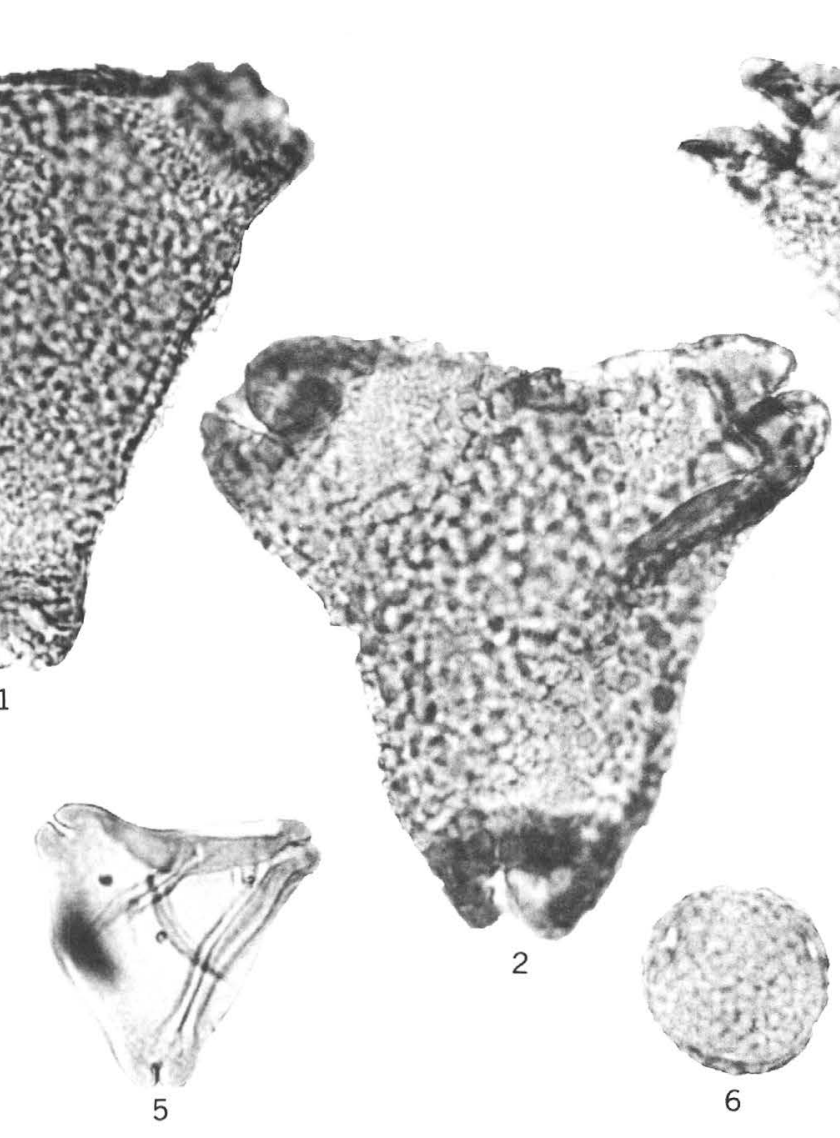

PROFESSIONAL PAPER 770 PLATE 11
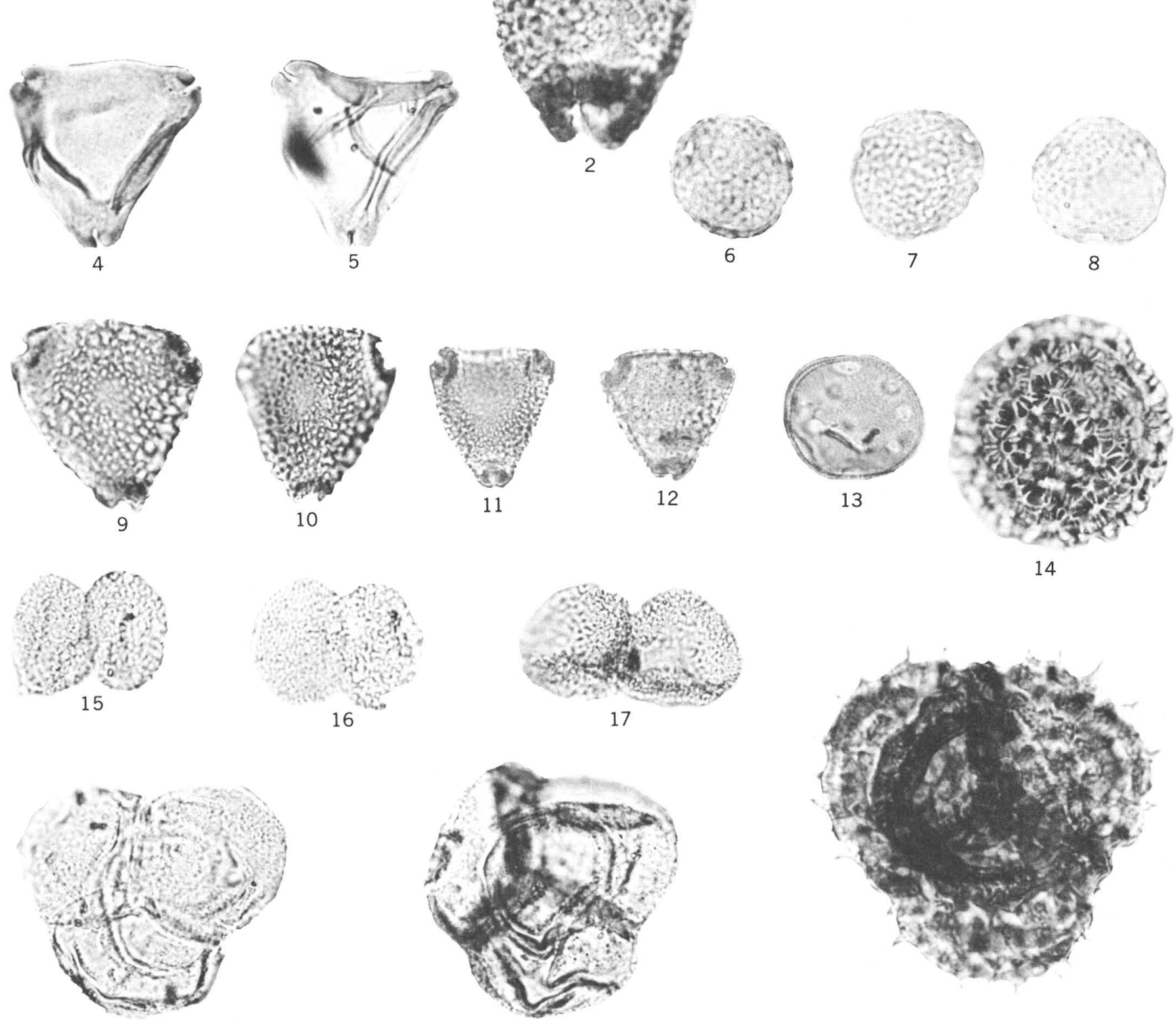

18
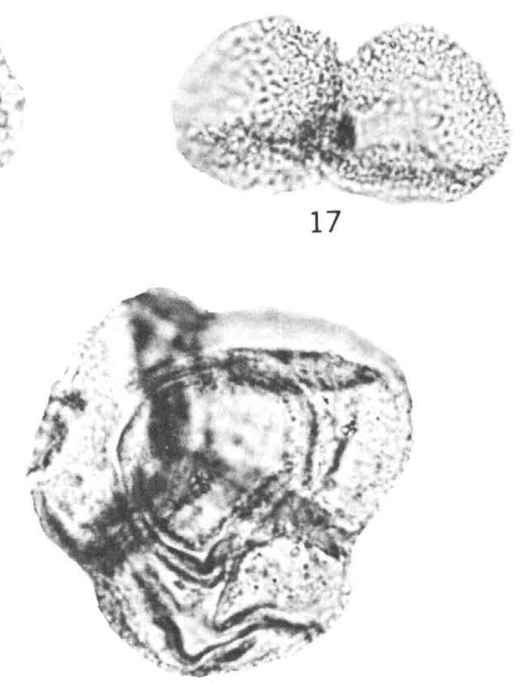

17

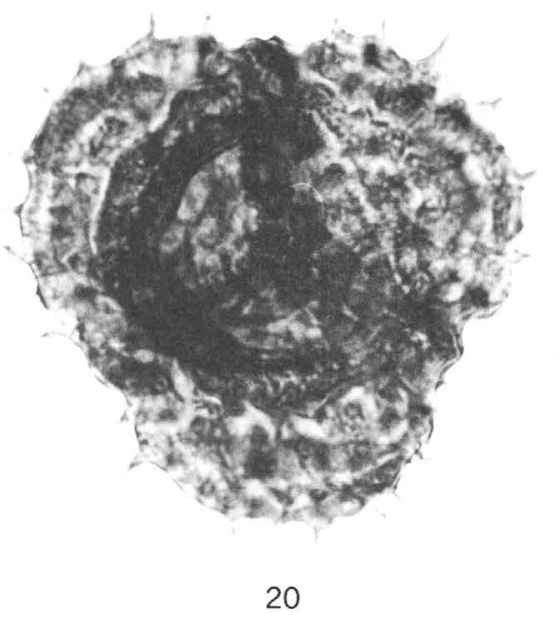

MONTANAPOLLIS, SIBERIAPOLLIS, TRIATRIOPOLLENITES, SUBTRIPOROPOLLENITES, PROTEACIDITES, PERIPOROPOLLENITES, ERDTMANIPOLLIS, DYADONAPITES, 
